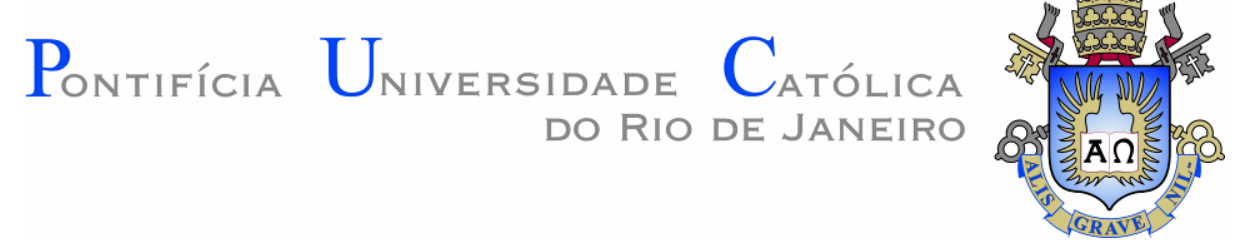

Daniele Fernanda Feliz Moreira

\begin{abstract}
OS VÁRIOS GÊNEROS DA PRODUÇÃO ARTÍSTICA DE CAROLINA MARIA DE JESUS E A LITERATURA MARGINAL CONTEMPORÂNEA
\end{abstract}

Tese de Doutorado

Tese apresentada ao Programa de Pós-graduação em Letras da PUC-Rio como requisito parcial para obtenção do grau de Doutor em Letras.

Orientadora: Prof. Marília Rothier Cardoso

Rio de Janeiro

Abril de 2019 


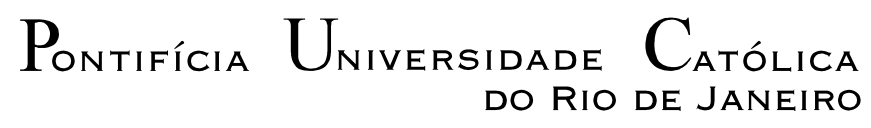

Daniele Fernanda Feliz Moreira

\section{OS VÁRIOS GÊNEROS DA PRODUÇÃO ARTÍSTICA DE CAROLINA MARIA DE JESUS E A LITERATURA MARGINAL CONTEMPORÂNEA}

Tese apresentada como requisito parcial para obtenção do grau de Doutor pelo Programa de Pós-Graduação em Literatura, Cultura e Contemporaneidade da PUCRio. Aprovada pela Comissão Examinadora abaixo.

Profa. Marília Rothier Cardoso

Orientadora

Departamento de Letras - PUC-Rio

Profa. Mariana Patrício Fernandes

Departamento de Letras - PUC-Rio

Profa. Beatriz dos Santos Damasceno Departamento de Letras - PUC-Rio

Profa. Fátima Maria de Oliveira CEFET/RJ

Prof. Paulo Roberto Tonani do Patrocínio UFRJ

Rio de Janeiro, 30 de abril de 2019. 
Todos os direitos reservados. É proibida a reprodução total ou parcial do trabalho sem autorização da universidade, da autora e do orientador.

\section{Daniele Fernanda Feliz Moreira}

Graduou-se em Letras pela Universidade Federal do Rio de Janeiro em 2011. É especialista em Relações Étnico-raciais e educação pelo Centro Federal de Educação Tecnológica Celso Suckow da Fonseca, possui mestrado em Relações Étnico-raciais pela mesma instituição, tendo obtido o título em 2014. Trabalhou como professora colaboradora do Departamento de Educação da Universidade Estadual do Rio de Janeiro, com foco em metodologias, práticas educativas, questões raciais e identitárias. Atualmente é professora da Secretaria Municipal de Educação da cidade de Maricá, atuando na Educação de Jovens e Adultos.

Ficha Catalográfica

Moreira, Daniele Fernanda Feliz

Os vários gêneros da produção artística de Carolina Maria de Jesus e a literatura marginal contemporânea / Daniele Fernanda Feliz Moreira ; orientadora: Marília Rothier Cardoso. - 2019.

$93 \mathrm{f}$; $30 \mathrm{~cm}$

Tese (doutorado) - Pontifícia Universidade Católica do Rio de Janeiro, Departamento de Letras, 2019.

Inclui bibliografia

1. Letras - Teses. 2. Carolina Maria de Jesus. 3. Literatura. 4. Marginal. 5. Periferia. 6. Negritude. I. Cardoso, Marília Rothier. II. Pontifícia Universidade Católica do Rio de Janeiro. Departamento de Letras. III. Título. 
Para minha mãe,

maior fonte de aprendizagens. 


\section{Agradecimentos}

À minha orientadora, sem ela definitivamente meu trabalho não seria possível. Agradeço sempre pela paciência, apoio e boa vontade,

Ao meu marido, pelo apoio emocional e intelectual,

Aos professores que participaram da comissão examinadora, por dedicarem seu tempo na leitura de meu trabalho,

À minha família, por me incentivar e inspirar a continuar prosseguindo, 


\title{
Resumo
}

\begin{abstract}
Moreira, Daniele Fernanda Feliz; Cardoso, Marília Rothier. Os vários gêneros da produção artística de Carolina Maria de Jesus e a literatura marginal contemporânea. Rio de Janeiro, 2019. 93 p. Tese de Doutorado - Departamento de Letras, Pontifícia Universidade Católica do Rio de Janeiro.
\end{abstract}

A presente pesquisa tem como objetivo analisar o trabalho de Carolina Maria de Jesus à luz de temas como: gênero, raça, arte e política, considerando sua posição incisiva entre casos isolados de escritoras do passado e a geração atual de artistas, ligada a movimentos de periferia e iniciativas da vertente brasileira do chamado feminismo negro. Explora-se o protagonismo da autora de Quarto de despejo, tanto na ampliação do campo da literatura quanto, com sua agudeza ao expor experiências vividas, levanta e discute questões econômico-políticas, com vistas a uma tomada de posição libertária. O trabalho se valerá de contrapontos entre a obra variada e complexa de Carolina e as intervenções de escritores e performers das periferias, nos anos 2000, diante das transformações no panorama cultural do presente, quando emergem, em especial, motivos de negritude e ancestralidade nas pautas do debate contemporâneo.

\section{Palavras-chave}

Carolina Maria de Jesus; Literatura; marginal; periferia; negritude; feminismo. 


\title{
Resumen
}

\begin{abstract}
Moreira, Daniele Fernanda Feliz; Cardoso, Marília Rothier. Los varios géneros de la producción artística de Carolina Maria de Jesus y la literatura marginal contemporánea. Rio de Janeiro, 2019. 93 p. Tese de Doutorado Departamento de Letras, Pontifícia Universidade Católica do Rio de Janeiro.
\end{abstract}

La presente investigación tiene como objetivo analizar el trabajo de Carolina María de Jesús a la luz de temas como: género, raza, arte y política, considerando su posición incisiva entre casos aislados de escritoras del pasado y la generación actual de artistas, vinculados a movimientos e iniciativas periféricas del lado brasileño del llamado feminismo negro. Los trabajos de la autora de la obra Cuarto Despejo es explorado, tanto en la ampliación del campo de la literatura y, con su nitidez en exponer experiencias vividas, proponer y discutir cuestiones económico-políticas, teniendo en vista una posición libertaria. El trabajo utilizará contrapuntos entre el trabajo variado y complejo de Carolina y las intervenciones de escritores e intérpretes de las periferias en los años 2000, ante las transformaciones en el paisaje cultural del presente, cuando emergen, especialmente, motivos de negritud y ancestralidad en los patrones del debate contemporáneo.

\section{Palabras clave}

Carolina Maria de Jesus; Literatura; marginal; periferia; negrura; feminismo. 


\section{Sumário}

1. Introdução

2. Carolina Maria de Jesus: uma literatura contestada 12

2.1. Mulheres negras e literatura: entre o canônico e o marginal 12

2.2. Um teto todo seu: a reivindicação do lugar de escritora 26

2.3. Vida por escrito: inquietação, revolta e plenitude 30

2.4. Carolina e as várias dimensões de seu legado artístico 35

3. Literatura, cultura e representação: diálogos marginais 41

3.1. Do Canindé ao Capão Redondo 42

3.2. Terrorismo literário 53

$\begin{array}{ll}\text { 3.3. Moradas } & 57\end{array}$

3.4. Negritude e ancestralidade 63

4. Múltiplas artes: a periferia e suas possibilidades expressivas 70

4.1. O artista e suas múltiplas linguagens 71

4.2. Arte e política: literatura, negritude e o engajamento necessário 75

4.3. Literatura expandida: da literatura marginal ao mainstream 83

4.4. Carolina Maria de Jesus: a redescoberta do século XXI 86

5. Conclusão 89

6. Referências bibliográficas 90 
A Periferia nos une pelo amor, pela dor e pela cor.

Dos becos e vielas há de vir a voz que grita contra o silêncio que nos pune. Eis que surge das ladeiras um povo lindo e inteligente galopando contra o passado.

A favor de um futuro limpo, para todos os brasileiros.

A favor de um subúrbio que clama por arte e cultura, e universidade para a diversidade. Agogôs e tamborins acompanhados de violinos, só depois da aula.

Contra a arte patrocinada pelos que corrompem a liberdade de opção. Contra a arte fabricada para destruir o senso crítico, a emoção e a sensibilidade que nasce da múltipla escolha.

A Arte que liberta não pode vir da mão que escraviza.

VAZ, Sérgio. Manifesto da Antropofagia Periférica 


\section{Introdução}

Esta pesquisa nasce no curso de especialização em Relações Étnico-Raciais e Educação oferecido pelo Centro Federal de Educação Tecnológica Celso Suckow da Fonseca (CEFET-RJ). Mas antes disso, a busca pela investigação da cultura/literatura de periferia começou em 2011, em um estágio não obrigatório da faculdade de Letras da UFRJ, em uma escola municipal pertencente ao Complexo do Alemão. Na minha pesquisa de dissertação dediquei-me aos estudos literários aplicado na educação. Trabalhei com a produção de literatura marginal de viés racial oferecendo uma proposta de aplicação da Lei $10.639 / 03^{1}$. E a minha conclusão foi a de que, de certa forma, Carolina Maria de Jesus é responsável também pelos desdobramentos da Literatura Marginal contemporânea. Mesmo que ela não tenha articulado um movimento, Carolina foi um exemplo, uma inspiração, a demonstração de uma possibilidade, a possibilidade da escrita independente de formação acadêmica e contexto social.

Como professora de língua portuguesa, seja atuando na educação básica, seja trabalhando no ensino superior, procuro mostrar aos meus alunos que é importante reconhecermos outras perspectivas e que o mundo não está dado, a luta pela visibilidade artística dos marginalizados, tão talentosos como aqueles que estão no centro das questões, deve ser contemplada nos espaços educativos e culturais. Apresentar aos meus alunos a experiência de ler Carolina, delinear sua trajetória e propor reflexões a partir disso, é um modo de quebrar um ciclo tradicional em que predomina homens, brancos e abastados. Se vir representado de modo não caricato é um dos principais ganhos da Literatura produzida fora das convenções, Literatura essa de Carolina, Ferréz, Sérgio Vaz e tantos outros. Mesmo que Carolina tenha escrito num passado não tão recente, seu legado cada vez mais adquire força em nosso tempo.

E na busca pelo entendimento da relevância dos trabalhos de Carolina no século XXI eu utilizo, para além de outras estratégias, o instrumento de releituras. A releitura consiste em um modo de interpretação que tem como finalidade ler uma obra por meio de uma referência artística para reinterpretá-la. Assim, o ato de "reler", ler

\footnotetext{
1 Trata-se da inclusão do estudo da História da África e dos Africanos, a luta dos negros no Brasil, a cultura negra brasileira e o negro na formação da sociedade nacional, resgatando a contribuição do povo negro nas áreas social, econômica e política pertinentes à História do Brasil. Os conteúdos referentes à História e Cultura Afro-Brasileira deverão ser ministrados no âmbito de todo o currículo escolar, em especial nas áreas de Educação Artística e de Literatura e História Brasileiras.
} 
novamente, possibilita uma nova visão a respeito da obra original. No caso dos autores em questão, existe a diferença histórica e a questão de gênero que conduzem as peculiaridades de cada obra, mas eles também partilham olhares e experiências em comum.

Este texto está dividido em três partes, no primeiro momento é analisada a dificuldade de inserção de Carolina no universo literário. As questões de gênero e a própria retrospectiva comparativa estabelecida com outras duas escritoras mostram as definições sociais que se fazem presentes no país desde os tempos mais remotos. $O$ segundo capítulo trata da questão das releituras em si. A última parte é dedicada a refletir sobre algumas questões referentes aos impactos e desdobramentos da escrita literária pelos mais pobres. De modo geral, o texto se propõe a analisar a validade dos trabalhos de Carolina para o contexto atual, na tentativa de demonstrar que o fenômeno "Quarto de despejo" nos anos 1960 não foi compreendido como deveria porque a autora estabelecia uma discussão que ainda não tinha lugar naquela sociedade. Por isso, Carolina foi vista como fenômeno exótico, ocupando lugar nos estudos a partir de uma perspectiva sociológica.

Sendo assim, no capitulo II, o trabalho de Carolina Maria de Jesus será estudado à luz de temas como: gênero, raça, arte e política, esta seção abordará a temática da escrita feminina negra considerando os legados de Maria Firmina dos Reis e Auta de Souza, ambas antecessoras à Carolina. O capítulo também discute a pertinência de autoras contemporâneas que lançaram teorias fundamentais para se pensar as particularidades do feminismo negro. A luta pelo direito à escrita, pela oportunidade de ser lida e reconhecida, esbarra nas questões de gênero, classe e cor. A necessidade e a relevância de se difundir o trabalho da autora é o tema da última subseção do capítulo, nele, será discutido a Literatura como um direito humano, a partir da contribuição teórica de Antônio Cândido.

No capítulo III, as relações estabelecidas entre as obras de Carolina Maria de Jesus e os autores marginais, como Allan da Rosa, Ferréz e Sério Vaz, serão analisadas a partir das perspectivas da literatura, cultura e da representação. Esta seção tratará de algumas questões relacionadas à formação da Literatura no Brasil, seus desdobramentos culturais e de aspectos representacionais, discutindo as transformações no panorama literário brasileiro a partir de eventos históricos. A análise levará em consideração a formação das favelas na década de 1950, aspectos culturais sobre as transformações da cidade de São Paulo e a realidade de Carolina nesse panorama.

Uma das propostas da presente pesquisa é explorar os múltiplos trabalhos confeccionados por Carolina Maria de Jesus ao longo de sua vida. A autora ficou 
conhecida por suas biografias, a mais famosa, "Quarto de despejo", Ihe rendeu maior popularidade. Carolina compôs e cantou músicas, escreveu romance, poesias, tem um livro de provérbios e tem roteiros teatrais escritos. É importante destacar que nas periferias brasileiras os investimentos culturais são escassos, e o contato com instituições artísticas públicas e/ou privadas que fomentem interesse da população local são ínfimos. O capítulo trata justamente das estratégias elaboradas por essas populações tão ricas artisticamente, dando ênfase às questões do artista e suas múltiplas linguagens, possibilidades, tendo como recorte os anos 1960 em diante. 


\section{Carolina Maria de Jesus: uma literatura contestada}

"Escritores boicotam, mas Carolina (favelada) autografou 600 livros", divulgou o jornal Última Hora, no Rio de Janeiro, em 20 de agosto de 1960. O artigo menciona ainda que somente os escritores Fernando Góes e Maria de Lourdes Teixeira compareceram à tarde de autógrafos, na livraria Francisco Alves. Na mesma data, a Folha da Noite de São Paulo publicava que "A favelada Carolina começou seu grande dia autografando o livro Quarto de despejo". Os noticiários em questão demonstram o quanto o trabalho de Carolina foi questionado, mesmo a escritora sendo um fenômeno de vendas. Assim, é possível constatar que, para além do mercado editorial, é preciso que o escritor tenha algum tipo de prestígio, que esteja alinhado com os anseios da classe que fomentava a literatura brasileira até então.

Tendo como objetivo geral da pesquisa analisar o trabalho de Carolina Maria de Jesus à luz de temas como: gênero, raça, arte e política, esta seção abordará a temática da escrita feminina negra considerando os legados de Maria Firmina dos Reis e Auta de Souza, ambas antecessoras de Carolina. O capítulo também discute a pertinência de autoras contemporâneas que lançaram teorias fundamentais para se pensar as particularidades do feminismo negro, no Brasil e no mundo. A luta pelo direito à escrita, pela oportunidade de escritas de mulheres serem lidas $e$ reconhecidas esbarra nas questões de gênero, classe e cor. A partir do ensaio de Virgínia Woolf, "Um teto todo seu", é possível estabelecer aproximações e contrastes entre as reflexões da autora britânica e o universo de Carolina. Nas obras de Carolina, é notória a recorrência de inquietações e revoltas, mostrando o caráter libertário dessa escrita. A necessidade e a relevância de se difundir o trabalho da autora é o tema da terceira subseção do capítulo, nele, será discutida a literatura como um direito humano, a partir da contribuição de Antônio Cândido.

\section{1}

\section{Mulheres negras e literatura: entre o canônico e o marginal}

Até a abolição da escravidão no Brasil, em 1888, o negro era considerado "coisa", propriedade, bem. A abolição não trouxe significativas melhorias para essa população, uma vez que a mesma passou a ser enxergada como um obstáculo para o desenvolvimento do país enquanto projeto de nação, principalmente tendo em vista a 
necessidade de se forjar uma identidade própria, "pura", "branca", inspirada nos moldes europeus do período. Mesmo não gozando dos mesmos direitos dos brancos, os negros passam a compor o cenário nacional de outra forma, já que continuam subestimados embora não tendo mais oficialmente o status de mercadoria. Em relação a essa questão, Renato Ortiz afirma que:

No final do século XIX, com a abolição da escravatura e a proclamação da República, a afirmação "o Brasil é um país mestiço resultado do cruzamento de três raças, o branco, o negro e o índio", impõem-se cada vez mais (lembro que no romance $O$ guarani, publicado em 1857, o negro encontra-se ausente da história narrada; o silêncio é expressivo das contradições existentes em torno da instituição da escravidão). Este será o tema central em torno do qual evolui a busca da identidade nacional.

(ORTIZ, 2013 p. 614)

O projeto nacionalista presente no período romântico destacava a figura do indígena como herói nacional e também como o elemento puro e ao mesmo tempo valente. A literatura brasileira se vale da figura do negro desde os tempos do poeta Gregório de Mattos, porém, como mencionado por Domíncio Proença Filho, é no século XIX que se personificam os estereótipos que prevalecem até a atualidade com alguma variação. Em seu artigo, ao escrever sobre a mulher negra, Giovana Xavier ${ }^{2}$ menciona que "Ao longo dos oitocentos, suas imagens foram utilizadas por diferentes escritores como metáfora da patologia, da corrupção e do primitivismo, configurando o corpo feminino negro como doente e, portanto, nocivo à saúde de uma nação em construção".

Se no campo da representação a figura da mulher negra era ignorada ou estereotipada, no ramo da produção literária, dois nomes merecem atenção: Maria Firmino dos Reis, lançando seu livro em 1859 e Auta de Souza, com publicação de versos em 1900.São duas mulheres negras que divulgam seus trabalhos e apresentam uma trajetória distinta da corriqueira de seus respectivos períodos. Maria Firmina dos Reis nasceu na cidade de São Luís, no Maranhão, em 11 de outubro 1825 e faleceu no ano de 1917. Ao longo dos seus 92 anos de vida, teve uma participação significativa como cidadã e intelectual, já que desenvolveu atividades como

folclorista, compositora e escritora. Firmina foi professora e desenvolveu algumas atividades na imprensa local. Seu mais importante trabalho, o romance

\footnotetext{
${ }^{2}$ XAVIER, Giovana et al (Orgs.). Entre personagens, tipologias e rótulos da "diferença": a mulher escrava na ficção do Rio de Janeiro no século XIX In: Mulheres negras no Brasil Escravista e do pósemancipação. São Paulo: Selo Negro, 2012.
} 
Úrsula, foi lançado em 1859, uma obra que aborda a escravidão a partir do ponto de vista dos escravos.

O cenário literário exclusivamente masculino, branco e burguês não fez com que a autora recuasse de seus propósitos, no entanto Firmina em seu prólogo de Úrsula demonstra certo desconforto:

Sei que pouco vale este romance, porque escrito por uma mulher e mulher brasileira, de educação acanhada e sem o trato e conversação dos homens ilustrados, que aconselham, que discutem e que corrigem, com uma instrução misérrima, apenas conhecendo a língua de seus pais, e pouco lida; o seu cabedal intelectual é quase nulo ${ }^{3}$.

Possivelmente por pensar dessa forma, Firmina não divulga seu nome no exemplar que foi encontrado pelo pesquisador. Em Úrsula, ela assina como "uma escritora maranhense". É Horácio de Almeida que, na década de 1970, publica uma edição facsimilar da obra Úrsula, é ele também quem escreve o prólogo dessa edição.

A autora, ou por modéstia ou temerosa da crítica, oculta-se no anonimato. Declara-se, no prefácio do livro, de pequeno cabedal nas letras para tão ousado empreendimento, sem convívio, ao menos, com homens letrados de quem pudesse receber conselhos. Era mulher e mulher do interior de uma província. Mesmo assim, dava a lume o fruto de sua imaginação, como a mãe matuta que enfeita o filho para com ele aparecer em público.

(FILHO, Nascimento Moraes, 1975, p. 2)

É importante destacar que o exercício da escrita foi uma atitude ousada para uma mulher negra do século XIX, Firmina extrapola as barreiras sociais que the são impostas, não obedece à configuração que a sociedade patriarcal e escravocrata estabelece e transgride simbolicamente seu lugar de subalternizada. Horácio de Almeida tece, ainda no prólogo de Úrsula, uma breve avaliação geral em relação ao romance e afirma que

Os horizontes em que exerce a ação do livro são demasiado limitados. Uma prosa árida, jungida a preocupações escorreitas, como era moda ressoa através de duzentas páginas. Aqui e ali, como uma pedra de tropeço, topa o leitor com uma palavra fora de uso, exumada dos clássicos. No mais, carece o romance de outros requisitos, como o colorido das descrições, a fixação dos costumes, a espontaneidade do estilo coloquial. Com relação ao coloquial, predomina o tratamento de vos entre todos os personagens, até mesmo os mais humildes, os escravos, que não claudicam nas formas verbais. Porventura, não são também artificiosas as obras literárias dos tempos românticos?

(FILHO, Nascimento Moraes, 1975, p. 2)

\footnotetext{
${ }^{3}$ REIS, Maria Firmina dos. Úrsula. Florianópolis: Mulheres; Belo Horizonte: PUC-Minas, 2004.
} 
Esse cuidado excessivo é fruto de uma preocupação e idealização do universo literário, a autora Carolina Maria de Jesus, mesmo tendo tido pouca formação escolar, fazia uso de um vocabulário extravagante, inspirado em autores clássicos. É de certa forma, um meio de se conceber, de se fazer parte da literatura, de acreditar que a autoria está relacionada à escrita com correção gramatical e vocabulário rebuscado, principalmente por aqueles que valorizam e almejam esse espaço. Mas Horácio de Carvalho lê um romance, claramente afiliado aos padrões românticos, pelos critérios da verossimilhança realista e da exigência moderna de naturalidade ou coloquialismo. O emprego de uma linguagem nobre, por parte da autora do século XIX, pode ser considerado como uma forma de autoafirmação. Comprovando seu amplo conhecimento da língua portuguesa, Firmina provaria a capacidade das mulheres, mesmo que negras ou mestiças, de dominar as exigências da arte literária.

Para além da necessidade de se adaptar a um universo que não é propriamente o seu, conforme exposto por Firmina -- "Sei que pouco vale este romance, porque escrito por uma mulher e mulher brasileira, de educação acanhada e sem o trato e conversação dos homens ilustrados (...)" (FILHO, Nascimento Moraes, 1975 , p. 5) --, o trabalho da autora, assim como o de Carolina, apresentam um valor artístico que supera os quesitos estéticos postos em questão pela crítica. Maria Firmina dos Reis trata da escravidão a partir de uma perspectiva diferenciada, já que é preciso considerar que estava afastada da Corte e do círculo abolicionista da maioria dos intelectuais de sua época. No entanto, um importante evento histórico ocorria entre os anos de 1838 e 1840.

Cabe ressaltar porém que, antes disso, em 1822 ocorria no então estado do Maranhão uma independência política, fato que gerou divisões, rivalidades e fragmentações políticas no seio da elite maranhense.Com isso, surge a necessidade de expulsão dos portugueses e demais estrangeiros para que se garanta certa "nacionalidade", surge também a proliferação de ideias em prol da liberdade, mais precisamente entre os escravizados. A partir de 1838, no bojo da Revolta dos Balaios, surge um movimento de insurreição, com foco na região de Itapicuru, que inicialmente, chegou a concentrar 20 mil negros no Maranhão. Liderados por negro Cosme, também conhecido como "tutor e imperador da liberdade", a resistência negra se alastrou por toda a região, configurando e fortalecendo quilombos e propagando ideais abolicionistas, tendo seu fim em uma batalha com as tropas governistas em 1840. Já em 1841, Cosme Bento das Chagas é julgado e condenado à morte. 
Dá-se fim a uma rebelião executando seu líder e eliminando seu exército, no entanto, não é possível controlar os vestígios que a partir dela se estabelecem. Firmina publica seu livro em 1859 e não à toa a temática de Úrsula está estruturada em uma perspectiva abolicionista. A atmosfera de seu momento histórico mostra-se impregnada por anseios libertários, a questão da abolição se fazia presente no Maranhão. É por isso que no livro podemos observar que a africana Susana, destina a Túlio, personagem recém alforriado, um discurso sobre a impossibilidade de ser totalmente livre em uma terra escravocrata. A liberdade era a África, e a obra traz passagens sobre o tráfico negreiro e a necessidade de regressar à terra de origem. $\mathrm{Na}$ solenidade de seu discurso, elaborado através da erudição da autora, as narrativas desses personagens revelam a ousadia da escritora:

\begin{abstract}
Meteram-me a mim e a mais trezentos companheiros de infortúnio e de cativeiro no estreito e infecto porão de um navio. Trinta dias de cruéis tormentos, e de falta absoluta de tudo quanto é necessário à vida passamos nessa sepultura até que abordamos as praias brasileiras. Para caber a mercadoria humana no porão fomos amarrados em pé para que não houvesse receio de revolta, acorrentados como animais ferozes das nossas matas que se levam para recreio dos potentados da Europa.
\end{abstract}

(FILHO, Nascimento Moraes, 1975, p. 18)

O relato da personagem Susana é escrito nove anos após a Lei Eusébio de Queirós (1850), que proibia o tráfego de escravos, mas antecede a famosa publicação "O navio negreiro, tragédia no mar", de Castro Alves, que data de 1868. Firmina constrói ainda, na figura de Túlio, um homem negro, recém liberto, crítico da situação vigente e saudosista.

Oh! A mente isso sim ninguém a pode escravizar! Nas asas do pensamento o homem remonta-se aos ardentes sertões da África, vê os areais sem fim da pátria e procura abrigar se debaixo daquelas árvores sombrias do oásis, quando o sol queima e o vento sopra quente e abrasador (...)

(FILHO, Nascimento Moraes, 1975, p. 21)

Os registros ficcionais de Firmina são de grande importância porque se mostram inovadores ao demonstrarem uma perspectiva diferenciada em relação à situação da escravidão. A autora estabelece uma relação humana, afetiva, entre o continente africano e as pessoas que ao chegarem ao Brasil foram escravizadas. É um conteúdo inovador, já que é importante destacar que, conforme exposto pelo próprio Renato Ortiz, o silêncio era a estratégia utilizada em relação à instituição da 
escravidão, essa era a opção dos autores do período. A escravidão, pela imposição da violência, pela brutalidade e comercialização das pessoas, ficou encarregada de implementar uma espécie de "coisificação" da pessoa humana escravizada. Por meio dessa lógica, os africanos escravizados eram bens, propriedade privada de quem pudesse pagar, não tinham história, família, terra natal. O texto de Firmina vai trazer a dimensão humana que a escravidão apagou, Firmina dá-Ihes nomes, conta suas histórias, transcreve suas aflições, desvela seus laços familiares, descreve suas terras, mostra o orgulho de suas origens.

É o olhar sensível, poético e humano que aproxima a escritora Maria Firmina dos Reis de Carolina Maria de Jesus. Duas escritoras, de momentos históricos distintos, expõem através da literatura suas concepções em relação à situação do negro no Brasil. Reminiscências da escravidão compõem a narrativa de Diário de Bitita, memórias da infância de Carolina no interior de Minas Gerais. Na introdução do livro de mesmo nome, Uelinton Farias Alves, escreve:

De origem humilde, de estirpe de uma família vinda da escravidão, então há apenas 26 anos abolida no país, analfabeta e pobre, a vida da menina Bitita, como comumente a conheciam, era um rosário em que se intermeavam a tristeza profunda e a miséria quase absoluta.

(JESUS, Carolina Maria de. 2016, p. 3)

Carolina aborda diversos temas em Diário de Bitita, faz um panorama de sua configuração familiar, fala da pobreza e da escassez vivenciada no período e acrescenta algumas reflexões acerca da situação dos negros no pós-abolição. Se a escritora Firmina tinha a personagem Susana como uma figura ancestral, dotada de capacidade crítica, sempre disposta a dar conselhos ao jovem Túlio, a menina Bitita, retratada como a própria Carolina na infância, também teria tido a sagacidade de perceber a distância entre a mudança legal e a situação de fato da população de afrodescendentes: "Quando os pretos falavam: - Nós agora estamos em liberdade. Eu pensava: 'Mas que liberdade é essa se eles têm que correr das autoridades como se fossem culpados de crimes?'” (p. 59). É possível perceber que, tanto Carolina, quanto Firmina, questionam o conceito de liberdade definido pela "branquitude". Isto porque a liberdade advinda de uma carta de alforria, concedida ao personagem Túlio, tinha pouco valorem uma sociedade em que ele não gozava do status de cidadão. $\mathrm{E}$ até mesmo no momento posterior à abolição, Carolina se pergunta sobre a valia dessa liberdade e o que ela significava.

A "branquitude" é um conceito amplo, mas que se concentra na percepção de que se trata de um lugar de privilégios simbólicos forjados na construção social e na reprodução de preconceito racial. Assim, burocraticamente uma pessoa deixa de ser 
escravizada, no entanto, perante a estrutura social de poder vigente nada é modificado. Ao tratar da temática da descolonização, Frantz Fanon, em sua obra Pele negra, máscaras brancas", afirma que "De tempos em tempos ele (o negro) luta pela Liberdade e pela Justiça, mas se trata sempre de liberdade branca e de justiça branca, de valores secretados pelos senhores". (FANON, 2008, p. 183). Portanto, a liberdade concebida a partir de parâmetros da branquitute não serve aos anseios de justiça, já que seu significado é esvaziado. Carolina reflete sobre a questão racial ao longo de toda sua obra. É a menina Bitita, revestida de sua astúcia infantil, quem traduz algumas experiências para o leitor. A escrita memorialística reflete sobre os dramas raciais e compartilha uma busca por respostas diante da incongruência dos eventos presenciados.

\begin{abstract}
O fato que me horrorizou foi ver um soldado matar um preto. O policial deu-Ihe voz de prisão; ele era da roça, saiu correndo. O policial deu-Ihe um tiro. Abala penetrou dentro do ouvido. O soldado que deu-lhe o tiro sorria, dizendo: - Que pontaria que eu tenho! Com o pé, ele movia o corpo sem vida do infausto e dia: - Ele deve ser baiano. E eu fiquei pensando nos baianos que eram obrigados a deixar a Bahia porque lá não chove, e serem mortos pelos policiais. (...) Ele não brigou, não xingou, não bebeu pinga. Não havia motivos para matá-lo. Quando o delegado chegou, olhou o morto, e mandou sepultá-lo. E tudo acabouse. O soldado que matou o nortista era branco. O delegado era branco. $\mathrm{E}$ eu fiquei com medo dos brancos e olhei minha pele preta. Por que será que o branco pode matar o preto? Será que Deus deu o mundo para eles? (...) Estava com seis anos. O único lugar seguro para eu guardar os fatos era dentro da minha cabeça. Minha cabeça é um cofre (...).
\end{abstract}

(JESUS, 2016, p. 115 e 116)

Carolina Maria de Jesus propõe ao leitor uma reflexão sobre a condição do negro em 1920, mas ao mesmo tempo é inevitável não ponderarmos sobre a situação atual, quase 131 anos após a abolição. As perguntas de Bitita, revestidas de absurdo e desespero, mostram a sensação de impotência experienciadas pela menina naquele momento. Mesmo assim, o texto de Carolina questiona o poder do Estado sob o corpo negro e ainda afirma que não é prudente emitir suas opiniões, a alerta se destaca justamente pelo fato de que, sendo ela, no momento em que se dão os fatos narrados, uma menina de apenas seis anos de idade, já compreendia que não é seguro adotar determinadas posturas.

Diário de Bitita não é o livro mais famoso da escritora, é um trabalho que inicialmente foi lançado na França, publicado só depois de seu falecimento. Carolina Maria de Jesus atingiu sucesso repentino com Quarto de despejo: diário de uma favelada, nos anos 1960. É a partir desse livro que ela surge nos meios literários. 
Mesmo obedecendo ao formato de diário, constando de datas e eventos cotidianos de sua vida, a obra Quarto de despejo mostra que Carolina assumia uma postura crítica e combativa em relação ao descaso do Estado em relação às vidas negras. Repleto de narrativas e construções impactantes, Quarto de despejo vai muito além de um relato de uma "favelada", conforme circulou amplamente na mídia e na crítica literária dos anos seguintes à publicação.

\begin{abstract}
Havia um pretinho bonitinho. Ele ia vender ferro lá no Zinho. (...) Um dia eu ia vender ferro quando parei na Avenida Bom Jardim. No Lixão, como é denominado o local. Os lixeiros haviam jogado carne no lixo. E ele escolhia uns pedaços: Disse-me: -Leva, Carolina. Dá para comer. Deu-me uns pedaços. Para não magoá-lo aceitei. Procurei convencê-lo a não comer aquela carne. Para comer os pães duros ruídos pelos ratos. Ele disse-me que não. Que há dois dias não comia. Acendeu o fogo e assou a carne. A fome era tanta que ele não pôde deixar assar a carne. Esquentou-a e comeu. Para não presenciar aquele quadro, saí pensando: faz de conta que eu não presenciei esta cena. Isto não pode ser real num país fértil igual ao meu. Revoltei contra o tal Serviço Social que diz ter sido criado para ajustar os desajustados, mas não toma conhecimento da existência infausta dos marginais. (..) No outro dia encontraram o pretinho morto. Os dedos do seu pé se abriram. $O$ espaço era vinte centímetros. Ele aumentou-se como se fosse de borracha. (...) Não trazia documentos. Foi sepultado como um Zé qualquer. Ninguém procurou seu nome. Marginal não tem nome.
\end{abstract}

(JESUS, 2016, p. 32)

Ao usar em seu discurso as expressões "um pretinho bonitinho" e "marginal", Carolina enfatiza a invisibilidade de seus companheiros de infortúnio. A passagem descrita enfatiza o caráter desumano da fome no país, mas a autora ressalta que essa fome tem cor, mesmo não tendo nome ou qualquer outro tipo de individualidade com algum resquício de dignidade. Maria Firmino dos Reis explora a questão da desumanidade no também impactante relato sobre as condições de um navio negreiro: "Para caber a mercadoria humana no porão fomos amarrados em pé para que não houvesse receio de revolta, acorrentados como animais ferozes das nossas matas que se levam para recreio dos potentados da Europa" (FILHO, Nascimento Moraes. 1975, p 38)

É importante destacar que tanto Firmina, quanto Carolina Maria de Jesus tiveram percalços em seus trabalhos no âmbito literário. A invisibilidade e o apagamento ao longo da história da literatura brasileira em relação às suas produções demonstram como é composto o cânone literário. Cabe ressaltar, portanto, que questões como gênero, classe e raça foram empecilhos em suas trajetórias.

$\mathrm{Na}$ reflexão sobre as finalidades da literatura na sociedade, seus mecanismos de aceitação e prestígio, o autor francês, Antoine Compagnon, ao discorrer sobre os poderes literários em Literatura pra quê?, aplica o conceito aristotélico de mimeses 
para afirmar que a literatura deleita e instrui. $O$ autor escreve que, a partir do Século das Luzes, a literatura passa a ser vista como possibilidade que liberta o indivíduo de suas sujeições às autoridades, cura do obscurantismo religioso e, sobretudo, como instrumento de justiça, já que proporciona autonomia que contribui para a liberdade e para a responsabilidade dos indivíduos. Ao aplicar apenas dois dos conceitos básicos oferecidos por Compagnon sobre as possibilidades da literatura, é possível perceber que Firmina e Carolina produziram materiais significativos para seus respectivos períodos históricos. E, então, cada escritora ao seu modo, com as ferramentas que Ihes cabiam, construiu significativo registro literário, fazendo com que tal registro cumprisse o papel iluminador e liberal, atribuído à arte, desde o século XVIII.

O espaço da mulher negra na literatura vem-se apresentando inexistente ou, no máximo, controverso, em avaliações mais recentes. Um terceiro caso para se pensar esse lugar, fruto de lutas de mulheres negras do passado e só possível de ser concebido pela contemporaneidade, vale lembrar-se da escritora Auta de Souza. Com uma trajetória muito distinta da de Firmina, a poetisa potiguar Auta de Souza é um outro dentre os raríssimos documentos da força da autoria feminina negra no Brasil. Auta nasceu em Macaíba, ponto estratégico na economia da província do Rio Grande do Norte. É de família abastada, filha dos proprietários da firma Paula, Eloi \& Cia, uma das mais importantes da época naquela região. Um de seus principais biógrafos descreveu a autora como "Tornara-se moça, airosa, morena, esculpida em polpa de sapoti, cheia de corpo, graciosa, mais baixa do que alta, com uma voz inesquecível de doçura e musicalidade" (CASCUDO, 1961, p. 45), fazendo referências ao seu tom de pele. Cascudo indica ainda que Auta se veste de modo a cobrir-se quase que inteiramente, ficando expostos somente as mãos e o rosto. A autora iniciou a vida intelectual muito cedo, aos 17 anos já publicava em uma revista na cidade de Natal. Teve acesso à educação, estudou em uma escola em Recife, exclusiva para meninas; o objetivo da escola era formar mulheres para o casamento ou então encaminhar para a vida religiosa, imprimindo, assim, os valores patriarcais do período. Auta teve uma vida intelectual intensa, em pouco tempo gozava de prestígio que ia além do nordeste brasileiro. Sua obra mais famosa, Horto, teve seu prólogo escrito por Olavo Bilac. Certamente a autora teve que desenvolver estratégias para participar de uma atividade reservada à elite social, pelo fato de ser mulher e também por apresentar traços negros. Certamente, teve que se enquadrar em parâmetros para que sua escrita fosse aceita. Sua escrita não faz menção direta à questão racial nem cita a questão de gênero. 
Vale destacar, porém, que Auta de Souza foi prestigiada em seu tempo, vivia em condições melhores do que muitos brancos de sua região. Conforme escreve Câmara Cascudo:

Havia a posição de poetisa cuja convivência honrava e distinguia. Citála entre as relações denunciava elevação e prestigio. Tinha recursos financeiros suficientes, residindo numa das melhores e mais amplas casas da cidade, irmã de chefe político, amigo de governador e do proprietário do partido oficial, senador Pedro Velho, vendo seus versos em todas as revistas da capital, e no próprio órgão do governo, onde era a única figura feminina na classe de colaboração regular.

(CASCUDO, 1961, p. 145).

Para além da questão do ciclo social de Auta, ela demonstrava ser uma intelectual naquela sociedade, tendo seu livro alcançado significativa repercussão literária em seu meio, comentado através de críticas positivas e negativas. Porém, cabe considerar a falta de circulação de seus escritos poéticos na contemporaneidade. Uma escritora com visibilidade e protagonismo social no século XIX, mas apenas nos limites de seu círculo. As pesquisas sobre a escritora ainda são tímidas, Auta teve uma vida curta, mas comparando o impacto atual de sua produção literária à de autores como Cruz e Sousa, por exemplo, o trabalho da escritora é pouco lembrado.

Mesmo que tenha traçado um percurso diferenciado na história da literatura brasileira, Auta se aproxima de escritoras como Firmina e Carolina, tanto no gesto ousado da empreitada da escrita, quanto na inconstância de seu lugar na literatura. As definições de marginalidade e canonicidade não dão conta dos percursos das escritoras em questão. É como se o lugar delas na literatura fosse um lugar imaginado, provisório, sempre subordinado às demandas do tempo, por vezes objeto de dúvida e desqualificação. Cada uma ao seu modo buscou mecanismos para se expressarem e continuarem produzindo seus textos. Firmina publica seu livro anonimamente, abrindo mão do prazer que é ter seu nome na capa. Carolina permite a publicação de seu diário, mesmo que esse não fosse o seu desejo de escritora, uma vez que produzia em diversos gêneros literários. Auta assume uma vida pública como escritora e intelectual, se expõe, se lança no mundo da literatura.

O olhar para o passado possibilita uma compreensão de que a representatividade negra, especificamente na literatura, é um fator que desencadeia uma série de questões. Ao analisar os conteúdos literários de escritoras como Maria Firmina dos Reis e Carolina Maria de Jesus, é possível perceber o quão engajadas na luta antirracista essas mulheres eram, e ainda cabe consolidar o valor literário de seus escritos, principalmente desenvolvendo um ponto de vista crítico isento de preconceitos. Não menos importante é olhar para a trajetória de Auta de Souza, que 
apresenta uma literatura que silencia temas caros à época, mas que tem como referência autoral, a figura de uma mulher negra, que contra todas as expectativas do período, atua na imprensa local e publica seu próprio livro de poesia.

Dando continuidade à temática da representatividade, cabe também uma breve análise sobre a pertinência de autoras contemporâneas que lançaram teorias fundamentais para se pensar as particularidades do feminismo negro, no Brasil e no mundo. O termo feminismo é amplo, abrangente e carrega consigo inúmeras possibilidades de leitura e entendimento. O objetivo deste trabalho não é discutir o feminismo negro e suas relações com o universo de Carolina Maria de Jesus, mas sim, propor algumas contribuições que auxiliem no entendimento da trajetória artísticoliterária da autora. Nesse sentido, é pertinente contextualizar e diferenciar as concepções sobre o termo feminismo.

Ao refletir sobre a vida conjugal na favela, Carolina escreve o seguinte:

Elas alude que eu não sou casada. Mas eu sou mais feliz do que elas. Elas tem marido. Mas, são obrigadas a pedir esmolas. São sustentadas por associações de caridade. Os meus filhos não são sustentados com pão de igreja. Eu enfrento qualquer espécie de trabalho para mantêlos. E elas, tem que mendigar e ainda apanhar. Parece tambor. A noite enquanto elas pede socorro eu tranquilamente no meu barracão ouço valsas vienenses. Enquanto os esposos quebra as tabuas do barracão eu e meus filhos dormimos sossegados. Não invejo as mulheres casadas da favela que levam vida de escravas indianas. Não casei e não estou descontente. Os que preferiu me eram soezes e as condições que eles me impuseram eram horríveis.

(JESUS, Carolina Maria de. 2014, p. 35)

É possível perceber que o discurso da escritora aponta para a questão das relações abusivas protagonizadas por homens que se valem de uma sociedade machista para cometerem atos violentos como espancamentos e humilhações contra suas parceiras. Carolina é de um período em que a banalização da violência contra a mulher fazia parte do cotidiano, o silenciamento e a indiferença, inclusive por parte das autoridades, eram práticas comuns. Entendia-se que na relação do casal ninguém deveria interferir. Carolina é a típica mãe solo, que trabalha e busca cuidar de seus filhos. A escritora entende que a vida conjugal pode lhe trazer mais problemas do que benefícios, já que também tem dedicação e disciplina em relação à literatura.

Carolina inicia o fragmento com a frase: "elas aludem que eu não sou casada, mas eu sou mais feliz do que elas." O casamento é uma instituição que, naquele período, confere status social, principalmente à mulher, mesmo que, na prática, a relação seja violenta. Muitas conquistas femininas se devem à prática feminista de olhar o passado e verificar as dificuldades que as mulheres enfrentaram ao optar pelo 
caminho da literatura. Mesmo constatando avanços significativos, é evidente que muito ainda pode ser feito. O século XXI trouxe maior presença da escrita das mulheres em relação à questão da representatividade; a escrita literária de Conceição Evaristo e o forte protagonismo político de Djamila Ribeiro demonstram isso. No entanto, alguns percalços sugerem que muito ainda há de ser feito.

Conceição Evaristo é atualmente uma das escritoras mais relevantes da literatura brasileira, seja por seu ativismo, seja por sua literatura peculiar, comprometida com um trabalho de conexão entre a ancestralidade e a figura feminina. Poemas de recordação e outros movimentos é um trabalho importante a ser visitado justamente por conter dois poemas que abordam a escritora Carolina Maria de Jesus e também por ter sido reeditado após o destaque da escritora, quando da recepção, em 2015, do prêmio Jabuti pela obra Olhos d'água. A reedição é uma forma de valorização e reconhecimento da trajetória de Conceição, uma vez que possibilita que o público tenha contato com seus trabalhos mais antigos. Poemas de recordação e outros movimentos, conforme o próprio nome sugere, é uma obra que valoriza a memória, a ancestralidade e também a feminilidade na construção identitária da função autoral. Conceição Evaristo estabelece em dois dos poemas um jogo intertextual entre Carolina Maria de Jesus e Clarice Lispector: "Carolina na hora da estrela" e "Clarice no quarto de despejo". É como se Carolina visitasse o trabalho de Clarice e Clarice visitasse o trabalho de Carolina. Conceição Evaristo, nesses dois poemas, faz citações dos trabalhos de Carolina e de Clarice, numa construção lúdica. Pode-se perceber, como resultado, a equiparação de importância dos trabalhos literários de Quarto de despejo e A hora da estrela, da mesma forma que a exposição dos dilemas de Carolina e Clarice enquanto escritoras.

Carolina na hora da estrela

No meio da noite Carolina corta a hora da estrela.

Nos laços de sua família um nó

- a fome.

José Carlos masca chicletes.

No aniversário, Vera Eunice desiste

do par de sapatos,

quer um par de óculos escuros.

João José na via-crúcis do corpo,

um sopro de vida no instante-quase

a extinguir seus jovens dias.

E lá se vai Carolina

com os olhos fundos,

macabeando todas as dores do mundo...

$\mathrm{Na}$ hora da estrela, Clarice nem sabe

que uma mulher cata letras e escreve

"De dia tenho sono e de noite poesia"

(EVARISTO, Conceição. 2017, p. 33) 
É como se Carolina entrasse no universo de Clarice, visitasse os trabalhos da escritora - como Laços de família, Via crucis do corpo, Água viva e concentrasse a atenção no auge da trajetória de Macabéa - protagonista de $A$ hora da estrela. No espaço do poema, Carolina intervém no momento mais importante do enredo e manda uma mensagem à protagonista, tratando de seu ofício, poetizando seus feitos Carolina é transportada para falar através da literatura de Clarice. Conceição também faz o movimento contrário praticando, mais uma vez, a intertextualidade, no poema "Clarice no quarto de despejo". É como se a escritora consagrada penetrasse o universo de Carolina e pudesse expressar-se através dele.

\author{
Clarice no quarto de despejo \\ No meio do dia \\ Clarice entreabre o quarto de despejo \\ pela fresta percebe uma mulher. \\ Onde estiveste à noite, Carolina? \\ Macabeando minhas agonias, Clarice. \\ Um amargor pra além da fome e do frio, \\ Da bica e da boca em sua secura. \\ De mim, escrevo não só a penúria do pão, \\ cravo no lixo da vida, o desespero, \\ uma gastura de não caber no peito, \\ e nem no papel. \\ Mas, ninguém me lê, Clarice, \\ Para além do resto. \\ Ninguém decifra em mim \\ a única escassez da qual não padeço, \\ - a solidão - \\ E ajustando o seu par de luvas claríssimas \\ Clarice futuca um imaginário lixo \\ e pensa para Carolina: \\ - a casa poderia ser ao menos de alvenaria \\ - E anseia ser Bitita inventando um diário: \\ páginas de jejum e de saciedade sobejam, \\ a fome nem em pedaços \\ alimenta a escrita clariciana. \\ Clarice no quarto de despejo \\ lê a outra, lê Carolina, \\ a que na cópia das palavras, \\ faz de si a própria inventiva. \\ Clarice lê: \\ - despejo e desejos - \\ (EVARISTO, Conceição. 2017 p. 35)
}

Clarice se desloca até o espaço de Carolina para compreender que os anseios da escritora estão além do universo por ela retratado. Frio, fome, pobreza nada são perto do desejo da escrita e das possibilidades inventivas que a literatura permite. Carolina confessa para Clarice que sente a necessidade de ser lida para além 
da temática da pobreza e da escassez. E é nesse encontro imaginado por Conceição Evaristo que Carolina pode ser lida como escritora, poeta, e tem algumas de suas obras também citadas, como Quarto de despejo - conhecida do público --; Diário de Bitita, Pedaços da fome e Casa de alvenaria - pouco divulgadas. Embora produzindo efeito artístico inferior ao da obra em prosa de Conceição, os poemas exigem atenção pelo fato de aproximarem as duas escritoras brasileiras - a mais reconhecida como canônica e a que, ainda, ocupa o limbo entre a literatura e a denúncia social. A inserção de Carolina Maria de Jesus no trabalho de Conceição Evaristo demonstra a importância do legado da escritora enquanto mulher negra e pobre para a geração atual e faz a própria Conceição Evaristo refletir sobre sua trajetória, já que:

\begin{abstract}
Eu me orgulho muito da minha formação e hoje posso afirmar que, se um ambiente letrado produz sensibilidade para escrita e para leitura, o ambiente não-letrado, com outras formas e experiências culturais, também produz. É uma espécie de vingança porque, uma vez já tendo o texto escrito, no meu caso e no de outras escritoras negras, é estar numa posição que a vida, de um modo geral, não permite. A pobreza é um lugar de aprendizagem, mas só quando você a ultrapassa. Se não, é uma situação apenas de dor. Para mim, a pobreza foi um lugar de profunda aprendizagem, mas é porque estou aqui agora. Para a grande parte que não consegue estar, a pobreza não é para ser contada.
\end{abstract}

(EVARISTO, 06/06/2017).

Estar nos lugares que a sociedade não libera e ser olhada com desconfiança, é situação emblemática de sua rejeição pela Academia Brasileira de Letras. Uma campanha mobilizou diversos intelectuais em 2018 para que Conceição Evaristo fosse eleita para a cadeira número 7 da ABL, anteriormente ocupada pelo cineasta Nelson Pereira dos Santos. Conceição não ocupou o lugar que tem grande força representativa. Apesar de ter "perdido" prestígio, a Academia Brasileira de Letras ainda é um lugar a ser conquistado pelos negros, principalmente pelas mulheres negras.

É importante lembrar que a questão da representatividade é uma pauta constante dos movimentos negros existentes não só no Brasil, mas também no mundo. Principal personalidade na luta feminista negra, Djamila Ribeiro, ao escrever o artigo intitulado "Quem tem medo de feminismo negro", traz a fala de Sojourner Truth, em 1851, mulher que foi escravizada, obteve sua liberdade e proferiu o famoso discurso "E não sou eu uma mulher?". A fala de Sojourner, na Convenção dos Direitos das Mulheres, em Ohio, anunciava que a situação da mulher negra era radicalmente diferente da mulher branca, já que, enquanto mulheres brancas lutavam em busca do sufrágio, as mulheres negras lutavam para terem o direito de serem consideradas seres humanos. Djamila utiliza a palavra feminismo sempre no plural -- feminismos. $O$ 
uso abrangente se faz necessário, uma vez que a luta por igualdade tem suas particularidades. A escrita feminina é uma empreitada já difícil por conta de questões sociais, no entanto, sendo a ativista (ou artista) negra, a desconfiança e o desprestígio são mecanismos comuns de negação de suas capacidades. A escrita de Carolina Maria de Jesus Sempre foi desmerecida, rotulada como testemunhal, biográfica, de protesto. São questões pertinentes, mas não é só esse lugar que ela ocupa. Sua escrita não pode ser reduzida ao exótico, seu trabalho é elaborado, poético, reflexivo; cumpre todas as exigências de um projeto literário. Djamila Ribeiro desconstrói o lugar conferido a Carolina, quando mostra que, se a mulher que seria vista pelo grande público, foi forçada a usar um lenço na cabeça e, assim, aparecer em fotografias nos jornais, sem chocar a boa sociedade de sua época, essa mulher tinha consciência do valor de sua escrita. Ela se apresentava, mesmo de pano na cabeça, com a dignidade de artista e escritora.

\section{2}

\section{"Um teto todo seu": a reivindicação do lugar de escritora}

As barreiras sociais - preconceitos e dificuldades práticas -- que envolvem o trabalho de escrita feminina constituíram o tema do consagrado texto "Um teto todo seu", de Virginia Woolf. A autora reflete sobre o tema 'mulheres e ficção', trazendo exemplos de como as mulheres eram vistas e retratadas na literatura em discrepância com a vida real. Virgina expõe um ideal literário da mulher retratada por homens e aponta as divergências existentes entre essa visão masculina e a maneira como as próprias mulheres se sentiam na realidade. A escritora vai além aponta os obstáculos que permeavam a realidade das mulheres de sua época. Dentre as observações de Virginia, estava a de que muitas mulheres não tinham como arcar com suas responsabilidades sociais e dar-se ao luxo de designar horas do dia para escrever. Muitas dependiam do dinheiro do marido já que não podiam trabalhar e, com isso, eram limitadas ao que era autorizado ou não. A conclusão de Virginia é a de que a sociedade teria mais autoras se elas pudessem ser detentoras de seus próprios recursos. A autora explica que só pôde se dedicar à literatura devido à herança que recebeu de sua tia, reduzindo suas preocupações financeiras. Escrever, para ela, deveria ser um ato de paixão sem custo, sem regras e sem grandes preocupações em relação a algum retorno financeiro.

Minha tia, Mary Beton, devo dizer-lhes, morreu de uma queda de cavalo, quando estava em Bombaim. A notícia da herança chegou 
certa noite quase simultaneamente com a da aprovação do decreto que deu $\mathrm{o}$ voto às mulheres. A carta de um advogado caiu na caixa do correio e, quando a abri, descobri que ela me havia deixado quinhentas libras anuais até o fim da minha vida. Dos dois - o voto e o dinheiro o dinheiro, devo admitir, pareceu-me infinitamente mais importante. Antes disso, eu ganhara a vida mendigando trabalhos esporádicos nos jornais, fazendo reportagens sobre um espetáculo de burros aqui ou um casamento ali; ganhara algumas libras endereçando envelopes, lendo para senhoras idosas, fazendo flores artificiais, ensinando o alfabeto a crianças pequenas num jardim de infância.Tais eram as principais ocupações abertas às mulheres antes de 1918. Acho que não preciso descrever em detalhes a natureza árdua do trabalho, pois talvez vocês conheçam mulheres que o tenham feito; nem tampouco a dificuldade de viver com aquele dinheiro, quando era ganho, pois é possível que vocês já tenham tentado fazê-lo.

(WOOLF, Virginia. 1985, p. 27)

Virginia narra suas dificuldades de uma perspectiva burguesa, já que antes de poder se dedicar exclusivamente ao trabalho de escritora, antes da herança de sua tia, a vida era mais incerta financeiramente. As atividades domésticas também tinham grande peso no cotidiano da maioria das mulheres do início do século XX. Suas principais funções sociais eram exercer o papel de "dona de casa" e "mãe". Por isso há uma dificuldade em se consolidar na vida literária, é difícil escrever, conseguir tempo, silêncio, diante de tantas responsabilidades. Sendo assim, para Virginia, a questão financeira é realmente um assunto de destaque dentro desse universo da produção literária feminina, já que possibilita liberdade e autonomia, ela ainda trata de temas como aceitação da sociedade, recepção crítica dessa obra e o prazer/necessidade da escrita. O trabalho se transforma em fardo quando suas necessidades são sufocadas.

Mas o que permanece ainda comigo como uma imposição (...) é o veneno do medo e da amargura que aqueles dias geraram em mim. Para começar, estar sempre fazendo um trabalho que não se queria fazer e fazê-lo como uma escrava, lisonjeando e adulando, nem sempre necessariamente, talvez, mas isso parecia necessário e os interesses eram grandes demais para correr riscos; e depois a ideia daquele dom único, que ocultar equivalia à morte (um dom pequenino, porém caro para sua possuidora), perecendo, e, com ele, o meu ego, a minha alma (..)fato, pensei, deixando a prata escorregar para dentro de minha bolsa e recordando a amargura daqueles dias, é impressionante a mudança de ânimo que uma renda fixa promove. Nenhuma força no mundo pode arrancar-me minhas quinhentas libras. Comida, casa e roupas são minhas para sempre. Assim, cessam não apenas o esforço e o trabalho árduo, mas também o ódio e a amargura. Não preciso odiar homem algum: ele não pode ferir-me. Não preciso bajular homem algum: ele nada tem a dar-me. Assim, imperceptivelmente, descobrime adotando uma nova atitude em relação à outra metade da raça humana. 
A escritora britânica afirma que a sociedade, por vezes era cruel com as escritoras, justamente por duvidar da qualidade do material baseado no gênero de quem escrevia. Se as mulheres europeias, brancas, oriundas de classes dominantes, tinham o olhar desconfiado de seus leitores por conta da questão de gênero, Carolina Maria de Jesus, no Brasil, era vista com desconfiança por conta da pouca escolaridade, por questões de gênero, de raça e de classe. Mas ainda assim, a literatura estava em seu cotidiano, Carolina persiste, insiste, mesmo diante de todas as impossibilidades. Em "Quarto de despejo", a autora retrata com frequência que os hábitos de escrita e de leitura estão permanentemente em sua vida, seja como prazer “... Eu gosto de ficar dentro de casa, com as portas fechadas. Não gosto de ficar nas esquinas conversando. Gosto de ficar sozinha e lendo. Ou escrevendo! (Jesus, 2014, p. 25)", seja como forma de apaziguar as tensões," (...) o nervoso que eu sentia ausentou-se. Aproveitei a minha calma interior para eu ler".

Assim como Virginia Woolf encontrou a liberdade na independência financeira, não necessitando de qualquer homem para sustentá-la, Carolina Maria de Jesus, fez da opção de não se casar um elemento de autonomia e maior dedicação para seus projetos artístico-literários. A autora entende o tipo de sociedade na qual está inserida, por isso reflete a questão de modo prático, analisando e ponderando sobre seu ideal.

O senhor Manuel apareceu dizendo que quer casar-se comigo. Mas eu
não quero porque já estou na maturidade. E depois, o homem não há
de gostar de uma mulher que não pode passar sem ler. E que levanta
para escrever. E que deita com lápis e papel debaixo do travesseiro.
Por isso é que eu prefiro viver só para o meu ideal

(JESUS, 2000, p. 44).

Tendo Carolina a dificuldade financeira e a responsabilidade de sozinha, criar e educar seus filhos, a escritora via no comprometimento afetivo amarras para que pudesse seguir com seus projetos. A artista plástica Marina Abramovic falou sobre as dificuldades de se prosperar no meio artístico sendo uma mulher, no livro "Quando Marina Abramovic morrer: uma biografia", tem o registro de que a autora nunca quis ter a responsabilidade de ter filhos porque pensava que isso a impediria de se dedicar à carreira, uma vez que, a maternidade exige muita responsabilidade e dedicação feminina. Marina diz que existe muitas mulheres brilhantes fazendo arte, no entanto o compromisso familiar, imposto socialmente, impede que estas mulheres consigam conciliar a carreira com a vida pessoal, diferente dos homens, que são maioria nesse meio. 
A escrita é uma forma de registro existencial, Carolina afirma que "Há coisas belas no mundo que não é possível descrever-se" (JESUS, 2000, p. 39). A autora busca se cercar de condições básicas para que possa dar prosseguimento ao seu trabalho, como registrado em "Que bom escrever atualmente com luz elétrica. A minha casa tem 14 lâmpadas (Jesus, p. 129). O empenho e a disciplina são marcas no cotidiano da escritora que, mesmo diante das adversidades, prosseguia obstinada em seu projeto. A pesquisadora Raffaella Fernandez ${ }^{4}$ ao estudar Carolina e construir 0 projeto de elaboração de sua biografia, afirma que a ideia de que a autora não é autora somente porque escreveu um diário é preconceituosa. Sob Carolina ainda recaí outros preconceitos, como a questão da escrita, fruto do pouco tempo que pôde frequentar a escola, em Sacramento, e ainda a cor de sua pele, o local em que residia, e o fato de ser mulher, mãe solo, livre, independente. Raffaella avalia que no mundo inteiro pessoas publicaram diários e receberam notoriedade por conta disso, casos como Getúlio Vargas, Josué Montello, Pedro Nava e Anne Frank. Se nenhum deles foi acusado de fazer "subliteratura" ou uma "literatura menor", por que afinal o trabalho de Carolina incomodava tanto e era de certa forma, menosprezado? Raffaella aposta na hipótese de que a quantia de dinheiro que Carolina ganhou incomodava algumas pessoas, já que rapidamente ela se tornou Best-seller, algo raro para o Brasil da época.

Mais do que questão financeira, que certamente deve ter trazido incômodo a determinados setores, Carolina não se submeteu e subverteu a ordem vigente porque não aceitava determinadas resoluções que não julgasse favoráveis para sua carreira. Ela não era uma pessoa manipulável, e isso desagrada pessoas que queriam usá-la para levantar determinadas pautas, sejam elas políticas, religiosas e/ou sociais. 0 lugar da escrita era o que sempre perseguiu, sempre almejou. As publicações de Carolina não só possuem conexões com elementos culturais de suas origens africanas e mineiras, a autora se valeu também da literatura de cunho romântico, da valorização da natureza e do olhar crítico diante de injustiças, ela desenvolveu um modo próprio de trabalhar a linguagem, utilizou seus recursos embasados de seus dramas cotidianos para compor seus textos de modo simbólico, realístico, fornecendo um material até então inédito na Literatura brasileira.

As questões de Carolina por vezes tocam os dramas de Virginia Woolf, ambas mulheres, escritoras, em busca de liberdade e reconhecimento para poderem se dedicar exclusivamente ao ofício literário. Se a questão financeira era um problema para as escritoras de modo geral poderem se consolidar no trabalho da escrita, os aspectos sociais como configuração familiar e machismo são amarras constantes para

\footnotetext{
${ }^{4}$ FERNANDEZ, Raffaella. Disponível em: <https://medium.com/revista-bravo/biografia-e-livro-de-inéditosampliam-olhar-sobre-carolina-maria-de-jesus> acesso em 24 mar. 2019
} 
o desenvolvimento pleno da escrita e obtenção de uma carreira na literatura. Carolina sofreu com a rejeição de seus livros, principalmente "Casa de alvenaria". Ao criticar e experienciar a hipocrisia social de uma classe que ela não conhecia, de apresentar uma proposta literária diferenciada das questões de "Quarto de despejo", e consequentemente não retratar mais a pobreza, a fome, erroneamente lidas e interpretadas como uma leitura exótica, ela então deixou de fazer sucesso. A escritora morreu pobre, voltando ao seu velho ofício de catadora, no entanto deixou em sua literatura um legado de aprendizagem, se tornando um símbolo de negritude, força e perseverança do ideal literário.

\title{
2.3
}

\section{Vida por escrito: inquietação, revolta e plenitude}

Carolina Maria de Jesus, muitas vezes é lida como um fenômeno social isolado, apartada de qualquer movimento que a legitimasse, amparasse ou até mesmo que a inspirasse em suas críticas. É Audálio a figura que em 1960, lança o primeiro diário de Carolina. É a ele que muitos se dirigem para conversar sobre "Quarto de despejo", ele é a figura apontada como idealizador e/ou possibilitador do então renomado Best-Seller da autora.. Mas Carolina era uma mulher inteligente, altamente informada em relação aos eventos que aconteciam no Brasil e no mundo. José Carlos Sebe Bom Meihy, no artigo "Ditos e interditos: Ensaio de despedida de Carolina Maria de Jesus", o autor escreve que no término de 1950 havia um céu diferente, constelando tipos sociais não percebidos como agentes ativos:

\begin{abstract}
"Entre tantos abalos exemplares naquela era, um bradava mais: a linhagem de negros que represavam 400 anos de submissão de "não lugar social". Sim, impunha-se o aparecimento de figuras "de cor" que se expressavam tanto no popular como invadindo territórios burgueses. Zé keti, Cartola e dona Zica, Lipicínio Rodrigues, Elza Soares, Ruth de Souza, Pixinguinha, Didi, Pelé, Garrincha, Grande Otelo, representavam, cantavam, driblavam, e apareciam. No terreno religioso, Mãe Menininha do Gantois e Mãe Stela, entre tantos dimensionavam um panteão de orixás transpostos para o Brasil, e, com eles, tradições africanas ganhavam adeptos evocando a "Mama África", parideira de gerações que então se salientavam. Nas academias, por sua vez, abriam-se espaços para figuras como o sociólogo Alberto Guerreiro Ramos, enquanto que nas artes, política e jornalismo Abdias do Nascimento figurava com expressões, impondo seu "Teatro Sentenciado", vertido depois no Teatro Experimental do Negro".
\end{abstract}

(MEIHY, José Carlos. 2015, p. 270)

O artigo em questão refuta a tese de que Carolina era uma escritora improvável, excepcional, uma estrela solitária. Na verdade, influenciada por essa atmosfera, leitora 
voraz de livros e revistas que encontrava nos lixos, ouvinte assídua de rádio, Carolina estava a par do que ocorria ao seu redor e isso certamente contribuiu para sua escrita. A escritora difere justamente da literatura convencional, produzida na e pela classe média, justamente por conseguir dimensionar na prática a situação absurda experienciada por ela e outros brasileiros e transformar isso em literatura. Oriunda de um espaço em que a escrita tinha pouca inserção, é ela mesma quem se faz visível ao mundo. A escritora pensa construindo a linguagem, conforme cita CHIARA : "Ela avaliava a cultura como um meio de superar a escassez de sua vida". Em "Quarto de Despejo", Carolina, retrata seu drama cotidiano em busca de meios para sobreviver perante a dureza dos fatos. Tema constante das analogias e constatações desafiadoras da autora, a favela e sua condição marginal são os que mais a incomoda. A favela do Canindé, com seus barracos, falta de saneamento, vizinhança perturbadora e toda ausência de estrutura que compõem esse universo são abordados de forma precisa no diário de Carolina. A construção espacial da autora se dá pela experiência do caos e da escassez, a luta pela sobrevivência ocorre diariamente. A perturbação e os conflitos domésticos configuram a favela do Canindé no olhar de Carolina, que, de modo recorrente em sua escrita se distancia dos demais componentes locais.

Carolina se identifica com o universo letrado, é a partir dele que estabelece sua escrita. Com apenas dois anos formais de instrução escolar, a autora se constrói como alguém que quer ocupar um lugar diferente do qual pertence. "Estou residindo na favela. Mas se Deus me ajudar hei de mudar daqui. Espero que os políticos estingue as favelas [...]". "Se eu pudesse mudar desta favela! Tenho a impressão que estou no inferno". A favela é o martírio de Carolina, mas ao mesmo tempo ela busca compreender e relevar certos acontecimentos porque entende que o contexto no qual ela e seus vizinhos estão inseridos é desumano. "Quando as mulheres feras invade o meu barraco, os meus filhos Ihes joga pedras. Elas diz: - Que crianças mal iducadas! Eu digo: - Os meus filhos estão defendendo-me. Vocês são incultas, não pode compreender". Para além das atitudes revoltosas que permeiam "Quarto de despejo", do constante tom de reprovação do comportamento de seus vizinhos, da denúncia de mazelas sociais e morais, está o compromisso materno. Os gestos afetuosos para com seus filhos perpassam todo o livro. O medo do alcoolismo é algo declarado pela própria autora, ela associa à doença a perda de responsabilidade.

"Hontem eu bebi uma cerveja. Hoje estou com vontade de beber outra vez. Mas, não vou beber. Não quero viciar. Tenho responsabilidade. Os meus filhos! [...] O que eu reprovo nas favelas são os pais que mandam os filhos comprar pinga e dá as crianças para beber. [...] 
encontrei o senhor Ismael com uma faca de 30 centímetros mais ou menos. Disse-me que estava a espera de Binidito e do Miguel para matá-los, que eles lhe expencaram quando estava embriagado. Lhe aconselhei a não brigar, que o crime não trás vantagens a ninguém, apenas deturpa a vida. Senti o cheiro de alcool, desisti. Sei que os ebrios não atende."

(DE JESUS, Carolina Maria, 2012, p. 47)

A relação com o espaço em que reside é motivo dos conflitos de Carolina. As favelas nos anos 1950 eram espaços de extrema pobreza. Temas constantes em seu cotidiano, a violência, a fome, o alcoolismo e o abandono por parte do Estado são assuntos que se desdobram em reflexões, questionamentos e críticas no diário de Carolina. A construção de Carolina como porta-voz da comunidade não era a proposta da autora, e apesar de promovida essa ideia de fundo comercial, Carolina jamais se identificou com a alcunha de favelada:

Comecemos o retraço crítico pelo subtítulo do "Quarto de despejo: diário de uma favelada. Favelada? Favelada simplesmente porque morou em uma favela? Carolina nasceu em uma pequena cidade tradicional do interior mineiro, perambulou pelo interior de Minas e de São Paulo até que chegou à capital paulista e então, sem lugar para morar, se depositou, transitoriamente, em uma favela nova e já ameaçada de extinção. Bastaria isto para defini-la como favelada? Ela nunca, jamais, se ajustou à vida de favelada, não compactuava em nada com a crônica "cultura da pobreza". Era estranha e estranhava seus vizinhos. Carolina apenas pode ser taxada de favelada a partir de visão externa, estreita, comercial.

(MEIHY, Cinderela negra, 1994, p. 34)

Muito diferente dos movimentos literários marginais da literatura produzida em periferias nos anos 2000 , em que os autores buscam a valorização do espaço, o orgulho da favela enquanto forma de pertencimento e exaltação dos que lá residem, Carolina, busca se desvencilhar do universo que a cerca: "Já faz oito anos que cato papel. O desgosto que tenho é residir em favela". Vale destacar que, o contexto de Carolina é a cidade de São Paulo, enquanto as favelas no Rio de Janeiro eram dotadas de uma cultura peculiar, marcadas por estratégias de sobrevivência e resistência baseadas na música, e na configuração que possibilitava a noção de grupo, de pertencimento e até certo orgulho. Um exemplo disso são dois sambas consagrados na cultura nacional, suas letras dão o tom dessas diferenciações. A primeira publicação de "Quarto de despejo" é em 1960, já em 1955, o sambista Zé Keti compõe a célebre letra de "A voz do morro", muito difundida e popularizada no filme "Rio 40 Graus". Em 1964, Zé Keti compõe outro samba muito famoso, "Opinião". Se 
em a "Voz do morro", o compositor canta em seus versos que "Eu sou o samba/ A voz do morro sou eu mesmo sim senhor/ Quero mostrar ao mundo que tenho valor/ Eu sou o rei dos terreiros", em "Opinião", já num gesto de resistência ao cenário político que se iniciava canta que "Podem me prender/ Podem me bater/Podem, até deixar-me sem comer/Que eu não mudo de opinião/Daqui do morro/Eu não saio, não". Conforme exposto anteriormente, a valorização e o orgulho davam o tom de algumas letras.

É importante destacar que, apartada dessa realidade, Carolina foi midiaticamente alçada ao posto de ícone da favela, numa espécie de representante dos "sem voz". Cabe mencionar que Carolina lançou seu diário porque foi o que the oportunizaram. A autora enviava seus textos inclusive para fora do país, na tentativa de ter alguma publicação lançada. É provável que suas anotações Ihe servissem como material para que posteriormente ela escrevesse realmente um livro sobre a favela, já que a própria autora afirmava que(...) vou escrever um livro referente à favela. Hei de citar tudo que aqui se passa. E tudo que vocês me fazem. Eu quero escrever o livro, e vocês com estas cenas desagradáveis me fornece os argumentos. Quarto de despejo é um livro que contém nomes reais, com datas, eventos e turnos precisos. A publicação do livro trouxe alguns contratempos para a escritora, que ao se mudar da favela do Canindé foi ofendida e atacada por seus vizinhos. A falta de autonomia e controle sobre sua trajetória foi um dos motivos que levaram a escritora a romper com Audálio Dantas.Com o dinheiro obtido da publicação de "Quarto de despejo", Carolina conseguiu deixar o Canindé e então em seguida a autora publica "Casa de alvenaria", seu segundo livro, que já não tem o alcance de sua primeira publicação. A aceitação crítica de Carolina enquanto fenômeno da literatura teve uma validade circunscrita e situada no estereótipo exótico. Carolina foi esquecida pela mídia, já que a ascensão econômica inicial não significou uma ascensão social. Permaneceu como um 'caso', um cometa, uma abertura na hegemonia do mercado editorial do período.

Característica marcante de significativa parte dos trabalhos de Carolina, a denúncia e a revolta são traços contundentes da escritora que, diante de cenas grotescas, mesmo ela estando habituada aos "desgostos" da favela, causavam-lhe repulsa. Carolina relata a situação de abandono dos pobres, tidos como marginais, sem identidade, amparo e dignidade. Sua escrita é um processo que tem em seu bojo questões como gênero, raça, maternidade e política. A escritora, no intuito de agrupar memórias e experiências que caracterizam o espaço e as relações em seu entorno, traça um olhar sobre si não como gesto meramente descritivo, mas como constitutivo de seu eu:

"Veio a D. Silvia reclamar contra os meus filhos. Que os meus filhos são mal iducados. Mas eu não encontro defeito nas crianças. Nem nos meus nem nos dela. Sei que criança não nasce com senso. O que 
aborrece-me é elas vir na minha porta para perturbar a minha escassa tranquilidade interior (...) Mesmo elas aborrecendo-me, eu escrevo. Tenho apenas dois anos de grupo escolar, mas procurei formar o meu caráter. A única coisa que não existe na favela é solidariedade."

(DE JESUS, Carolina Maria, 2012, p. 39)

Carolina constata que na favela não existe solidariedade por conta dos constantes problemas que enfrenta com os vizinhos por proteger seus filhos. A autora mostra-se solidária por entender que as crianças não possuem senso, e ao perceber que não existe recíproca por parte dos demais, caracteriza a favela como espaço que carece de solidariedade. É a maternidade, elemento constante e central em "Quarto de despejo" que constitui sua subjetividade, que mostra-se decisiva em determinadas falas, gestos e reflexões da escritora. Carolina lida com a preocupação de ter que trabalhar para garantir seu sustento e ao mesmo tempo assegurar a integridade física dos filhos: "Deixei as crianças brincando no quintal.[...] Trabalhei depressa pensando que aquelas bestas humanas são capazes de invadir meu barracão e maltratar meu filhos'. Ela também demonstra preocupar-se com o bem-estar das crianças: "Mandei fazer um balanço para os filhos para ver se eles permanecem no quintal”. Além das preocupações, são os filhos também os responsáveis por momentos de alegria: "As vezes ligo o rádio e danço com as crianças, simulamos uma luta de boxe. Hoje comprei marmelada para eles. Assim que dei um pedaço a cada um percebi que eles me dirigiam um olhar terno".

Para além da questão da maternidade, do afeto, dos esforços empreendidos por Carolina para preservar ao máximo o direito à infância de seus filhos, a escritora, na narrativa utilizada em Diário de Bitita, se vale do lúdico presente no olhar infantil para exprimir grande sensibilidade na percepção e descrição do seu inconstante mundo, permeado por seus familiares, vizinhos e algumas figuras da então cidade de Sacramento. O Diário de Bitita documenta seus esforços para, ainda na infância, encontrar trabalho, garantir a sobrevivência material e manter a dignidade. Suas memórias são repletas de eventos descritivos com riqueza de detalhes. Diferente de "Quarto de despejo", que se configura como escrita de um registro diário, o livro "Diário de Bitita" divide-se por temas, no entanto, algumas questões são abordadas frequentemente. A Reflexão sobre gênero, a constituição familiar a partir de uma perspectiva social e questionamentos políticos continuam a permear o trabalho da autora.

Bitita - Carolina na infância - busca o entendimento sobre as questões de gênero, ora identificando-se positivamente como heroína, ora tentando 
desesperadamente transformar-se em homem. "Uma mulher havia mandado um rei cortar a cabeça de São João Batista! Pensei: "As mulheres também mandam no mundo! Ah! Então eu também vou mandar [...]". E em outros momentos mostrava insatisfação. "Eu pensava que deveria ter passado por debaixo do arco-íris, para virar o homem correto para auxiliar os homens. [...]. E incorporava a figura masculina para ter legitimidade em seu um discurso. Durante uma briga com doutor Brand por conta de seu filho que lhe jogava frutas: "Quando o doutor Brand caminhou na minha direção, não corri e ele não me bateu. Minha mãe puxou-me: - Cale a boca, cadela! Gritei: - Deixa, isto aqui é uma briga de homem com homem.

A escrita de Carolina nos remete a questão do poder e o quanto esse poder está associado à figura masculina, é possível perceber através da autora que o jargão "de homem com homem/de homem para homem" tão presente na sociedade, tão comum em textos literários, é uma expressão que remete à assimetria existente entre homens e mulheres. É como se o agravamento da situação só pudesse ser resolvido com duas figuras masculinas, o leitor é levado a refletir sobre essa questão justamente porque se trata da fala de uma menina. A simplificação e a velocidade com que as crianças apresentam um desfecho para as situações cotidianas dão o tom de gracejo nas falas em questão. Bitita é ingênua, infantil, pura, quer resolver tudo de modo simples. Se o mundo se apresenta de modo mais difícil para as mulheres, a solução então é virar homem, e então ela dá vida a esse anseio, e de modo poético constrói criticamente um questionamento a respeito das posições sociais exercidas por homens e mulheres. É difícil ser indiferente ao trabalho de Carolina, ela faz da literatura uma experiência catártica pessoal e coletiva, é como se sua leitura possibilitasse outra dimensão de compreensão dos dramas humanos, ao mesmo tempo em que, quando ela o faz, reflete em si mesma a luta de uma escritora marginalizada que persegue incessantemente a literatura como espaço expressivo.

\section{4}

\section{Carolina e as várias dimensões de seu legado artístico}

O trabalho de Carolina Maria de Jesus deixa um legado importante. A escritora pode ser lida como percussora de uma tendência literária oriunda da periferia, seu trabalho pode ser interpretado como um grande marco no movimento negro, sua trajetória é símbolo de luta dos pobres, das mulheres, dos negros, dentre 
muitas outras possibilidades de leitura. Num momento de fortalecimento de movimentos representacionais, mesmo diante das inúmeras tentativas políticas de esvaziamento desses grupos de resistência e mobilização, cabe ressaltar a importante contribuição do teórico Antônio Candido em seu texto "Direitos Humanos e Literatura", uma vez que, ele aponta uma mudança de tratamento em relação às minorias.

No mesmo sentido eu interpretaria certas mudanças no comportamento cotidiano e na fraseologia das classes dominantes. Hoje não se afirma com a mesma tranquilidade do meu tempo de menino que haver pobres é a vontade de Deus, que eles não têm as mesmas necessidades dos abastados, que os empregados domésticos não precisam descansar, que só morre de fome quem for vadio - e coisas assim. Existe em relação ao pobre uma nova atitude, que vai do sentimento de culpa até o medo. Nas caricaturas dos jornais e das revistas, o esfarrapado e o negro não são mais tema predileto das piadas, porque a sociedade sentiu que eles podem ser um fator de rompimento do estado de coisas, e o temor é um dos caminhos para a compreensão.

(CANDIDO, Antônio. 1998, p. 2)

Para entender a fala de Antônio Candido, basta fazer a transposição temporal dos inúmeros comentários depreciativos e ultrajantes proferidos pela mídia no trato com Carolina e seu trabalho literário. É notícia no jornal Última Hora, em 27 de Outubro de 1960 que Carolina tem a intenção de processar a revista "Time", pela reportagem de David St. Clair. O jornalista escreve que Carolina teve mais de trinta empregos e que não conseguia permanecer nos empregos porque saía à noite para dormir com homens. A escritora diz ao jornal em questão que "O que não admito é que um jornalista estrangeiro venha me atacar e diminuir, visando minha moral, é sabido que os norte-americanos não gostam das pretas e quando escrevem sobre elas é para diminuí-las". A repercussão de tal gesto nos tempos atuais causaria constrangimento político, além do repúdio sobre o repórter e a pressão em relação à demissão do mesmo, uma vez que o fato de Carolina ser escritora nada tem a ver com esse aspecto de sua vida pessoal.

"Quarto de despejo" foi um livro lançado num período em que ainda era possível a manifestação expressiva de ideias racistas, machistas e classistas sem grandes repercussões. A obra teve um grande impacto em seu período, mas é notória a enorme proporção de seu legado a partir da segunda década do século XXI. A escritora foi ressignificada, é símbolo de inúmeros movimentos negros, dificilmente uma manifestação que tenham em pauta a questão da mulher negra desconsidera a pertinência do trabalho de Carolina. Isso porque, a experimentação de dispositivos expressivos artísticos é algo ainda recente para os grupos minoritários. O que não significa que eles não faziam arte anteriormente, significa que agora esses grupos se 
valem de recursos que anteriormente eram exclusividade da classe dominante. A literatura é um exemplo disso, a criação de um mercado editorial próprio, com selos artísticos, conteúdos e temáticas compartilhadas por esses grupos, bem como a maior acessibilidade e visibilidade de suas ações criativas por meio da internet, fazem com que seus conteúdos alcancem mais pessoas. O público que leu Carolina não era composto por seus vizinhos, pessoas pobres da favela do Canindé. Carolina foi lida por jornalistas, intelectuais, pessoas que compunham a elite. Esse é o resultado da extrema desigualdade social do Brasil, os mais pobres não têm acesso a bens culturais, a carência dessa população não é só em relação à alimentação, moradia, saúde.

Nesse sentido, Antônio Candido explica a importância de reconhecer que aquilo que consideramos indispensável para nós é também indispensável para o próximo. O crítico, ao esmiuçar os Direitos Humanos, reflete sobre o valor da literatura enquanto direito universal.

\begin{abstract}
Nesse ponto, as pessoas são frequentemente vítimas de uma curiosa obnubilação. Elas afirmam que o próximo tem direito, sem dúvida, a certos bens fundamentais, como casa, comida, instrução, saúde coisas que ninguém bem formado admite hoje em dia sejam privilégio de minorias, como são no Brasil. Mas será que pensam que o seu semelhante pobre teria direito a ler Dostoievskl ou ouvir os quartetos de Beethoven? Apesar das boas intenções no outro setor, talvez isto não Ihes passe pela cabeça. E não por mal, mas somente porque quando arrolam os seus direitos não estendem todos eles ao semelhante. Ora, o esforço para incluir o semelhante no mesmo elenco de bens que reivindicamos está na base da reflexão sobre os direitos humanos.
\end{abstract}

(CANDIDO, Antônio. 1998, p. 5)

Há o entendimento de que a luta pelos direitos humanos pressupõe a consideração não apenas dos bens que asseguram a sobrevivência física em níveis decentes, mas os que garantem também a integridade mental. Essa luta pela popularização da Literatura é algo acenado inicialmente pelo projeto modernista, já que naquele período alguns intelectuais viam a necessidade de uma aproximação com o popular, numa tentativa de maior interatividade, como objetivo de não estabelecer diretrizes somente na esfera representacional, mas também do ponto de vista prático. Na década de 1970 ocorre também um movimento de popularização literária, boicotando editoras, valorizando o instrumento livro como parte do processo artístico e autoral. No entanto, vale lembrar que tais atitudes surgem no seio de mobilizações e organizações burguesas, e encontram diversos empecilhos da efetiva popularização. É sabido que os movimentos culturais e artísticos ocorrem independentes da vontade política, mas eles podem ser incentivados, valorizados e promovidos. 
Do ponto de vista das iniciativas das minorias, vale lembrar que a cultura afrobrasileira sofreu inúmeras perseguições ao longo da história, o pesquisador Nilo Batista ${ }^{5}$ afirma que no século XIX expressões como a capoeira, traços religiosos do candomblé, além de censuradas, eram tidas pelas autoridades com uma forma de perturbação da ordem, sendo seus praticantes tidos como criminosos. Já no começo do século $\mathrm{XX}$, o hoje prestigiado samba também era visto pelas autoridades como prática criminosa, tipificada de vadiagem, no Código Penal de 1890. O funk, mesmo fazendo parte da cultura carioca há pelo menos 30 anos, somente nos últimos dez anos experimenta outras variações dadas em diferentes regiões brasileiras, no entanto, cabe ressaltar que, o ritmo tem uma aceitação social ambivalente. No campo da literatura de modo geral, foi somente a partir dos anos 2000 que grupos oriundos de periferias ganharam notoriedade em espaços legitimados e puderam se estabelecer a partir de suas próprias diretrizes.

A ascensão de movimentos literários periféricos somente nos anos 2000 é um evento histórico que diz muito não só sobre as políticas de incentivo à cultura no Brasil, como também da escassez de políticas públicas voltadas para a educação, haja vista no passado as elevadas taxas de analfabetismo no país. É preciso pensar sobre a real e efetiva estratégia de popularização da educação, e nesse sentido tratar da questão da educação não é só discutir a dimensão formal, escolar. Um plano efetivo que busque emancipação do pensamento requer tratar do assunto de modo amplo, agindo em comunidades vulneráveis, equipando-as com bibliotecas, teatros, cinemas, espaços culturais para atuações da própria comunidade. É sabido que atualmente no Brasil, o Estado quando propõe projetos culturais em comunidades periféricas se vale de parcerias com centros religiosos, majoritariamente igrejas protestantes que, interessadas na proximidade com a população local, disponibilizam seus espaços. Esses espaços são alternativas possíveis dentro das periferias, eles congregam lazer, convivência social, espiritualidade e vínculos afetivos. As manifestações artísticas que surgem nas periferias são em um primeiro momento condenadas socialmente, ou então apropriadas por determinados grupos e esvaziadas de seu valor, como ocorrem com o rap, o funk e o samba.

O legado de Carolina se faz presente de duas formas: do ponto de vista representativo, já que Carolina é um ícone muito lembrado no feminismo negro; e também pela potência de sua literatura, que de modo humano, retratou e poeticamente deu outro sentido existencial ao cotidiano de muitos brasileiros. Carolina foi ímpar, pioneira nesse sentido, lançou-se no cenário editorial e tornou-se uma

5 BATISTA, Nilo et al. Tamborzão: olhares sobre a criminalização do funk. Rio de Janeiro, Revan, 2013. 
referência de uma literatura que só ganharia espaço quarenta anos depois. Antônio Candido afirma que "a eficácia humana é função da eficácia estética e portanto o que na literatura age como força humanizadora é a própria literatura, ou seja, a capacidade de criar formas pertinentes", e foi isso que a autora fez. No tocante à questão da representatividade, Conceição Evaristo ${ }^{6}$ afirma que

A literatura que nós conhecemos, essa literatura canônica, ela não nos representa e quando nos representa é sempre de uma maneira limitada, de uma maneira estereotipada. Então o meu texto é um lugar onde as mulheres se sentem em casa, se sentem reconhecidas de verdade.

(CANDIDO, Antônio. 1998, p. 6)

A autora toca em um ponto central na discussão sobre literatura, acesso e Direitos Humanos: a questão da representatividade. Como problematizar a literatura enquanto direito humano sem tocar no tema representatividade? Como tornar a literatura acessível se as populações minoritárias não se veem representadas, seja no aspecto da autoria, seja em relação à temática, à ficção? Conceição Evaristo ${ }^{7}$ afirma que:

(...) tenho dito às vezes que a literatura pode ter um sabor de vingança. E digo vingança pelo silêncio que nos foi imposto. Aí volto outra vez à máscara de Anastácia. Um silêncio que nos foi imposto e foi rompido daquela forma. Para mim, simbolizou muito isso. Esses momentos que nós temos vivido na autoria negra não são momentos que nos foram concedidos, são momentos conquistados. Nós nos apossamos desse território com toda a certeza de que é uma posse de direito, justa e, digo mais, tardia.

Ter a literatura como um direito básico, fundamental, direito esse negado por anos há uma parcela significativa da sociedade, é um exercício que exige olhar para o passado e observar o quanto da população negra e pobre foi tirado. Para além das necessidades como moradia, saúde, alimentação, a privação do direito de fruição literária, do lazer e da representatividade também Ihes foram negados. Carolina Maria de Jesus é um exemplo de representatividade, de testemunho, de uso poético de linguagem como forma de contação de suas histórias. Portanto, a necessidade de Lêla.

Acho que temos a necessidade de ler os nossos textos. Até porque a nossa formação não é essa. Por exemplo, conheci Carolina Maria de Jesus fora da academia. Já Clarice Lispector e Lygia Fagundes Telles, conheci na academia. Hoje já há uma outra movimentação, há pesquisadores acadêmicos que estão trabalhando com textos de autoria

6 Disponível em: <https://medium.com/mulheres-que-escrevem/mulheres-que-escrevem>. Acesso em 12 mar. 2019.

7 ld. 
negra. Mas mesmo assim, nossos textos ainda não chegam com tanta veemência. Aliás, os textos de mulheres em geral não chegam e os de autoria negra muito menos. Então temos que procurar nos ler, conhecer mesmo os textos umas das outras. Se vale à pena ler Clarice Lispector, vale à pena ler Carolina Maria de Jesus.

Tão relevante quanto os nomes que permeiam o cânone, a literatura de Carolina é autêntica, retrata a pobreza como tema importante, de modo digno, enfático, cruel, real. A autora não utiliza suas vivências de modo pitoresco, ela se vale de suas opiniões, tecendo críticas sociais, abordando temas como racismo, infância e escassez. Conceição enfatiza sobre a importância de se fazer leituras de mulheres negras porque sabe a dificuldade que as mesmas enfrentam para se consolidarem nesse ofício. 


\section{Literatura, cultura e representação: diálogos marginais}

No capítulo 3, as relações estabelecidas entre as obras de Carolina Maria de Jesus e alguns autores marginais, como Allan da Rosa, Ferréz e Sério Vaz, serão analisadas a partir das perspectivas da literatura, cultura e da representação. Esta seção tratará de algumas questões relacionadas à formação da literatura no Brasil, seus desdobramentos culturais e de aspectos representacionais, discutindo as transformações no panorama literário brasileiro a partir de eventos históricos. A análise levará em consideração a formação das favelas na década de 1950, aspectos culturais sobre as transformações da cidade de São Paulo e a realidade de Carolina nesse panorama. A autora, poeticamente, em diversas obras, declara seu amor e seu ódio pela cidade, já que a oscilação entre tomadas de posição é frequente no trabalho dela. A perspicácia de seu olhar crítico, em paralelo com o impacto violento do cotidiano na favela, por certo, transformou as anotações de seus cadernos numa busca de definir aquele espaço, entre desabafo, acomodação, denúncia e sugestões para minimizar a miséria. Empurrada para a favela pela dificuldade de sobrevivência na zona rural, passava de um olhar de dentro para um olhar de fora, ganhando agudeza na observação e alternando o teor de suas avaliações.

Será levada em consideração a perspectiva da experimentação artística da cidade em momentos históricos distintos, na tentativa de estabelecer um diálogo entre a literatura de Carolina, na década de 1960, e a literatura de Ferréz, nos anos 2000. A proposta é fazer uma releitura dos trabalhos dos autores a partir da construção literária de ambos sobre suas experiências na periferia da cidade. Ainda dialogando com o escritor Ferréz, a partir de um texto emblemático do autor, "Terrorismo Literário", questões como recepção, crítica, pobreza e arte voltam a compor a discussão, mas de um ponto de vista mais literário, na forma de uma releitura.

A escrita como prática libertária, como morada, experiência emancipatória, é pauta principal nos escritos de Allan da Rosa. Assim, a casa como lugar no mundo, como cosmos, é construída enquanto possível primeiro universo do "eu". A partir de uma análise do vocábulo "morada" e das imagens do livro de mesmo nome, assinado por Allan Santos da Rosa e Leonardo Martins Galina(também conhecido como Guma),temas como favela, poesia e escrita vão se delineando em contraponto com o contexto de Carolina Maria de Jesus. Nos parágrafos seguintes, com relação a negritude e ancestralidade, será utilizada a perspectiva de Allan da Rosa acrescida de 
poemas do escritor Sérgio Vaz. O valioso livro das memórias de infância de Carolina, Diário de Bitita, traz ricos relatos de afetividade e histórias de seu avô. O tópico faz referência ao incentivo à preservação e propagação do conhecimento ancestral como forma de valorização da negritude e da luta antirracista.

\section{1}

\section{Do Canindé ao Capão Redondo}

A literatura é uma importante expressão artística e, como tal, ao longo da história da humanidade, as manifestações escritas ocupam significativo espaço dentre as formas de comunicação. É importante destacar também que desfrutar dessas experiências artísticas e estar conectado a um fluxo de relações de troca que fomentem essa capacidade humana ainda é para poucos. No Brasil especificamente, a arte tem origem no meio burguês. A literatura é trazida pelos europeus e desenvolve-se ao longo dos séculos no mesmo meio. Prestigiada por leitores específicos, produzida por uma camada ainda mais reduzida, somente a partir do Movimento Modernista Brasileiro é que se começa a vislumbrar a possibilidade de uma literatura com viés mais popular. Refletindo sobre os desdobramentos históricos da trajetória da literatura nacional em relação a seu acesso, inicialmente fomentado de modo ainda exíguo pelos modernistas, pensado e desenvolvido ao longo das décadas que se seguiram, apresente seção busca uma aproximação temática entre duas escritas diferentes, conduzidas por indivíduos de contextos temporais distintos. Tais objetos, no entanto, compartilham entre si alguns aspectos comuns de lugar de fala e, a partir disso, (re)criam mecanismos de sobrevivência. Cinquenta anos aproximadamente separam os textos de Carolina Maria de Jesus das diversas manifestações de projetos literários pensados na periferia de São Paulo e desenvolvidos pelos seus residentes.

Sendo assim, "Do Canindé ao Capão Redondo" se inicia com uma análise literária comparativa em que se contrasta o poema "Um caipira", presente na Antologia pessoal de Carolina, e o texto "Bula", escrito por Ferréz, no livro Ninguém é inocente em São Paulo. Os textos dialogam à medida que cada um constrói uma perspectiva sobre a cidade de São Paulo. Ambos chegam à conclusão de que a cidade é só desigualdade e desilusão. Carolina era mineira, passou a infância e parte da adolescência vivendo no campo, quando chega à cidade de São Paulo reside significativa parte de sua vida na favela do Canindé. Ferréz tem um perfil urbano, nasce em São Paulo, mas nem por isso encontra facilidades. O viés escolhido foi a abordagem das produções em prosa e poesia, presentes nas obras de Carolina e 
Ferréz. As experiências distintas vivenciadas pelos autores são importantes para se pensar o lugar de fala desses escritores, tanto no passado, anos 1950, quanto no momento contemporâneo, anos 2000.

São perspectivas distintas, baseadas na experiência, no testemunho, nas realidades rotineiras dos autores. Walter Benjamin (2013), ao tratar da questão da relevância das narrativas, assinala que o narrador está entre os mestres e os sábios, pois além de recorrer às próprias experiências, também se baseia na experiência alheia. As condições de vida, a rotina massacrante do trabalhador e as dificuldades enfrentadas pelos pobres são abordadas de óticas diferenciadas nos escritos de Carolina e de Ferréz, uma vez que os escritores são também testemunhas. Nessa condição, embora manifestando-se por escrito através do circuito midiático, guardam sobrevivências da tradição coletiva da narrativa oral - objeto da observação de Benjamin, em contraste com o romance moderno. Por isso, mesmo com um distanciamento temporal considerável é possível perceber na presença dos temas certas confluências entre o Canindé dos anos 1950 e o Capão Redondo dos anos 2000.

Primeiramente, é importante destacar que, ao final dos anos 1990 e início de 2000, se difunde e assume relevância nos grandes meios literários um movimento intitulado "Literatura Marginal". Este ganha destaque impulsionado por eventos que marcam o cenário cultural nacional, como o livro de Paulo Lins, Cidade de Deus, publicado em 1997, e a prestigiada adaptação para o cinema, aclamada pela crítica. Assim, os componentes do livro,-- favela, violência e marginalidade -- adquirem espaço e, até certo ponto, prestígio em espaços hegemônicos. A expressão "Literatura Marginal" é escolhida por Ferréz como forma de designação de sua escrita. $\mathrm{Na}$ introdução do livro Literatura marginal - Talentos da escrita periférica, o autor assegura que: "A Literatura Marginal, sempre é bom frisar, é uma literatura feita por minorias, sejam elas raciais ou socioeconômicas. Literatura feita à margem dos núcleos centrais do saber e da grande cultura nacional, isto é, de grande poder aquisitivo." (FERRÉZ, 2005, p. 4). O enfoque da palavra 'marginal', escolhida pelo autor para justificar seu trabalho, serve como destaque para designar minorias raciais ou socioeconômicas. Essa é uma importante característica a ser levada em consideração, já que é um fator de diferenciação entre esse grupo e os demais autores marginais da história da literatura nacional.

A situação de Carolina Maria de Jesus é diferente; quando a autora escreve, na década de 1950, não está inserida em um grupo, um movimento, apesar de vivenciar um contexto político-cultural efervescente. A formação ideológica, crítica e cultural são elementos fundamentais para a coesão de um grupo e, apesar das 
diferenças sociais e econômicas que estruturam os movimentos literários de 1922 , 1970 e 2000, existe um entendimento intelectual-artístico renovador para as propostas de produção literária, tanto que os comprometidos com os coletivos de contracultura da década de 1970 e os escritores de periferia dos anos 2000 tomam como exemplo e eixo paradigmático o movimento modernista. A articulação solitária é decisiva no impacto da vida intelectual de Carolina, na condição de voz isolada, ela foi vista como algo exótico e curioso e, assim, foi lida, mas não compreendida. A classe média e a elite cultural do período não entendiam a autora; estavam atrelados a uma concepção de literatura tradicional, burguesa, branca. E quando alguém subvertia essa ordem, seja em qual esfera fosse, as elites buscavam o esvaziamento de sentido do trabalho em questão.

Um exemplo dessa questão, anterior à década de 1950: Abdias do Nascimento criava o Teatro Experimental do Negro. A nomenclatura não agradava às elites e o objetivo de romper com o discurso "somos todos iguais" incomodava essa elite. E, por isso, em 1944, o jornal O Globo se opunha enfaticamente a esse empreendimento.

\begin{abstract}
Mas, a verdade, aliás ainda por ser largamente explanada, é que entre nós nem sequer historicamente essas distinções se fundamentaram, e, aparte os brados da consciência universal contra a escravatura, 0 drama humano da abolição e a voz do poeta dos escravos, seriam artificiais quase todas as obras de arte que exploram o tempo das senzalas porquanto, via de regra, os negros escravos, em todo país, eram mais bem tratados do que muitos que hoje vivem desamparados. Os crimes, os tormentos, eram exceções, porquanto a regra foi sempre a doçura brasileira, o fenômeno da mãe preta, dos escravos que, mesmo sobrevinda a abolição, ficaram por quase toda a parte a serviço dos seus senhores, e morreram acarinhados por todos. Sem preconceitos, sem estigmas, misturados e em fusão nos cadinhos de todos os sangues, estamos construindo a nacionalidade e afirmando a raça de amanhã.
\end{abstract}

(Jornal o Globo, 17/10/1944 apud teatro experimental do negro: testemunhos 1966, p. 12)

A mobilização de uma parcela não reconhecida, não valorizada, que não goza de status de cidadão é razão para incômodo e inconformismo se lê na matéria publicada no jornal $O$ Globo. O trecho destaca um convívio harmônico inexistente, já que as oportunidades conferidas à população negra e o acesso a direitos básicos foram sistematicamente negados ao longo do tempo. De modo perverso, a escravidão é romantizada, pelos termos que colocam negros e brancos nas mesmas condições, falseando a existência de uma relação harmônica, fraternal. O Teatro Experimental do Negro tinha a proposta de valorização social do negro e da cultura afro-brasileira por meio da educação e da arte, com intuito de propagar um novo estilo dramatúrgico, 
mais autoral e representativo, com uma estética própria. É sabido que os espaços artísticos ofereciam pouca representatividade racial, a própria Carolina Maria de Jesus tinha seus textos negados em circos, por exemplo, por ser negra.

Lidar com o racismo é uma realidade frequente nas periferias. E cada autor ao seu modo lidou com a temática em seus próprios recortes temporais. Instalados no eixo periférico, mais ou menos envolvidos com as questões sociais e de gênero, sempre compartilham reflexões sobre o racismo. A problematização racial é abordada tanto por Carolina, quanto por Ferréz em dois textos relevantes que compõem suas trajetórias. Escritos em prosa, Casa de alvenaria e a apresentação de Ferréz para a obra Literatura Marginal, intitulada "Terrorismo literário, levantam, cada um a seu modo, essa questão. Em Casa de alvenaria, diário que narra a vida de Carolina após o sucesso de vendas de Quarto de despejo, é possível encontrar uma reflexão da autora a respeito da questão racial, quando se refere à indignação de sua empregada: "'Meu Deus do céu, isto é o fim do mundo! Deus está me castigando. O mundo está virado. Eu, branca, ter uma patroa preta...' Eu dava risada e pensava: nós os pretos não revoltamos de ter patrões brancos. (...) Não sou exigente com as minhas empregadas. Não faço questão de cor.” (DE JESUS, , 1966, p. 20) Carolina ironiza o comportamento de sua empregada e avalia brevemente a situação trabalhista do negro. A autora conhece bem o lado apresentado, naquele momento, por sua funcionária.

Vale destacar que, em inúmeros trechos do livro, a autora se faz porta-voz de pessoas que relatam suas experiências com o racismo, seja quando comenta que "[u]m preto que é advogado conversava comigo citando a sua luta para estudar (...) foi servente de pedreiro. Estudava à noite" (p. 23). Ou quando um jovem negro pede para que ela coloque em seu livro que existe racismo no Sul. Por diversas vezes Carolina faz questão de sinalizar a presença de negros nos eventos de que participa. "No clube Renascença a festa estava animada. Os pretos do Rio estavam bem vestidos" (p.79). Em visita a cidade de Pelotas, Carolina fala da homenagem que recebeu do Clube "Fica Aî". Sendo assim, as questões raciais são sinalizadas pela autora e por diversas vezes também Carolina trata de seus desdobramentos e impactos sociais.

O prefácio de Ferréz para a coletânea Literatura marginal indica uma postura denunciativa que de certa forma era tendência nos escritos de Carolina. É preciso considerar que Carolina era menos incisiva, visto que se trata de contextos temporais distintos. No título de Ferréz a palavra 'terrorismo' designa um sistema governamental que impõe, por meio de terror, os processos administrativos sem respeito aos direitos dos cidadãos; ou então: ato de violência contra um indivíduo ou uma comunidade. $\mathrm{Na}$ primeira definição, 'impõe por meio de terror' está compreendido num sentido político, 
associado a uma espécie de regime marcado pelo autoritarismo. A segunda acepção 'ato de violência' é mais generalista e está atrelada à coação, opressão, tirania ou impetuosidade. Semanticamente, o vocábulo 'terrorismo' remete a uma série de definições negativas. No entanto, aparece sendo qualificada pelo termo 'literário', que diz respeito a letras ou à literatura; ou espécie de cultura relacionada com a arte da palavra. Dessa forma, "Terrorismo Literário" deve ser compreendido como um lugar de investimento ideológico, em que se articulam linguagem e poder na tentativa de se buscar uma mudança social.

Ferréz, em seu texto, estabelece um diálogo com o passado, ao mesmo tempo em que atualiza a questão trazendo elementos do presente. $O$ texto se inicia com: "A capoeira não vem mais, agora reagimos com a palavra, porque pouca coisa mudou, principalmente para nós"(FERRÉZ, 2008, p. 6). A capoeira foi uma forma de resistência utilizada por negros durante o período da escravidão no Brasil. Esta não é a única referência ao passado de que o autor se utiliza, seu texto é construído a partir de sua compreensão das relações de causa e efeito. O discurso de Ferréz constitui-se a partir da avaliação das políticas opressoras institucionais do passado e da desigualdade social de seu tempo - sua mensagem é uma réplica a outros enunciados, que negam tal situação.

Devido à grande discriminação racial, instituições especificamente negras, como o clube recreativo "Fica Aí", destaca-se por contribuir para a integração de uma sociedade demarcada racialmente na época do colonizador e que vem-se mantendo dividida, mesmo com a economia de consumo, através da intervenção de controles até mesmo da polícia . Ao mencionar fatos históricos como a doutrinação religiosa dos indígenas e a escravidão dos africanos, o autor emprega as expressões "antepassados" e "irmãos", evidenciando uma origem comum a ele mesmo e a seus representados. Assim, posiciona-se: "[a]o contrário do bandeirante que avançou com as mãos sujas de sangue em nosso território, e arrancou a fé verdadeira, doutrinando nossos antepassados índios, ao contrário dos senhores das casas grandes que escravizaram nossos irmãos africanos e tentaram dominar e apagar toda a cultura de um povo massacrado mas não derrotado". (FERRÉZ, 2008, p. 6)

Ferréz instaura sua fala a partir de uma memória trágica, repleta de mentiras e opressões; o autor aponta os culpados e atualiza seu discurso demonstrando que “(...) vivemos isso nas ruas, sob os olhares dos novos capitães do mato, policiais que são pagos para nos lembrar que somos classificados por três letras classes: C,D,E". (p. --) A figura da opressão, que no passado tinha como representante o "capitão do mato" - que capturava escravos fugitivos -, no presente é identificada com a imagem do policial. As abordagens em relação à questão racial, trazidas tanto por Carolina 
quanto por Ferréz, problematizam o viés racial impregnado na formação de nossa cultura e nas relações sociais cotidianas. Segundo Consuelo Dores Silva (1995), numa sociedade multirracial, a cultura dominante se impõe coercitivamente sobre outras culturas e os grupos dominados terminam por absorver a inferioridade.

Daí a relevância do questionamento de Carolina quando sua empregada se sente humilhada por ter uma patroa branca: "nós os pretos não revoltamos de ter patrões brancos" (DE JESUS, 1966, p. 24). Socialmente, a mulher branca acredita gozar de mais prestígio e possuir mais direitos do que uma mulher negra, então, sente-se injustiçada quando uma negra tem notoriedade e melhor situação econômica que a sua. Quando Carolina é homenageada em um clube negro de Pelotas e recebe um livro de prata com a inscrição: "Só o livro imortaliza um povo", a mensagem é muito significativa, já que de certa forma a elege como representante daquela comunidade, como seu porta-voz, apesar de a autora não se denominar assim. Se Carolina era motivo de admiração e orgulho para a comunidade negra na década de 1960, para os negros menos abastados e à margem das instituições, a escritora era esperança. $O$ canal que abria possibilidade de se fazer uma denúncia ou mesmo um desabafo, já que estava sempre atenta às questões raciais.

Em "Terrorismo Literário", explica-se que a absorção da inferioridade, por parte da população afrodescendente e marginalizada, se faz presente através da repetição cíclica da história. O escritor constrói um texto que atualiza o passado colonial e situa as minorias nas mesmas condições de precariedade. Apesar de demonstrar uma escrita mais combativa e revoltosa, Ferréz se aproxima de Carolina ao conferir à literatura o caráter de instrumento para lidar com a realidade amarga, como meio de acesso à cultura e principalmente como possível mecanismo de sobrevivência.

Outro caso importante está no livro Ninguém é inocente em São Paulo, onde Ferréz, no texto intitulado "Bula", escreve que o livro é uma reunião de "trechos de vida que catei, trapos de sentimentos que juntei, fragmentos de risos que roubei [e que] estão todos aí, histórias diversas do mesmo ambiente, de um mesmo país, um país chamado periferia"(FERRÉZ, 2005, p. 9). De caráter afetivo e teor crítico, o escritor reúne em seu livro perspectivas sobre São Paulo. Já a Antologia pessoal de Carolina Maria de Jesus é uma seleção de seus poemas, um deles, denominado "Um caipira", retrata a cidade de São Paulo a partir das referências da escritora. As ponderações espaciais dos autores são interessantes e, cada um ao seu modo, registra a cidade de, pelo menos, duas perspectivas distintas. Na visão de Carolina, o pobre é um misto de fragilidade, diante da "máquina" representada pela cidade de São Paulo, e contemplação, perante a imponência de sua arquitetura. São imagens que se 
contrapõem aos trabalhadores da perspectiva de Ferréz, já que o escritor os considera vítimas ao mesmo tempo em que responsáveis por sua situação, pois se acomodam diante das mazelas em troca de pequenas diversões.

O poema de Carolina foi composto segundo a tradição da poesia rimada e metrificada da língua portuguesa. A autora se esforça para atingir o padrão culto, ela almeja ao máximo a inserção de sua literatura nos meios de alto padrão cultural, para tanto, sente a necessidade de assumir uma escrita modelo, com metrificação adequada. Carolina imita os grandes escritores lidos ao longo de sua vida, procura incorporá-los em seus textos. Para Ferréz, atualizado com variedade de tendências da arte contemporânea, a preocupação em seguir a norma padrão como um procedimento para a escrita literária não é uma questão, uma vez que o próprio escritor afirma que a linguagem periférica é motivo de orgulho para as pessoas da periferia. Ferréz lê renomados escritores e reflete: "Um exemplo para guardar é o de Kafka. A crítica convencionou que aquela era uma literatura menor ${ }^{8} \mathrm{Ou}$ seja, literatura feita pela minoria dos judeus em Praga, numa língua maior, o alemão."(p. 39). Para Ferréz, a literatura na qual está inserido é uma literatura, também a exemplo de Kafka, feita por minorias, " (...) à margem dos núcleos centrais do saber e da grande cultura nacional (...)". O escritor afirma com entusiasmo que “(...) alguns dizem que sua [da literatura marginal] principal característica é a linguagem, é o jeito como falamos, como contamos a história (...)". (p. 6)

Tendo observado as questões em relação à linguagem, as preocupações métricas, formais e informais que compõem as pretensões textuais de ambos autores, é relevante debruçar-se sobre as perspectivas que Carolina e Ferréz mantinham em relação à cidade de São Paulo.

Como indicado, mais acima, Carolina era mineira, passou a infância e parte da adolescência vivendo na zona rural, quando chega à cidade de São Paulo reside significativa parte de sua vida na favela do Canindé. Ferréz nasce em São Paulo, mas nem por isso encontra facilidades. Morador de uma favela do Capão Redondo, inicialmente teve dificuldades em trabalhar com literatura. Em "Um caipira", poema de Carolina, São Paulo é o cenário triste para um homem vindo do interior que esbarra na pressa cotidiana da cidade. A principal queixa do "caipira" é em relação aos motoristas, sempre conduzindo seus carros em altas velocidades. O poema é quase infantil, as rimas são simples. Mas é possível compreender a angústia de um indivíduo que odeia São Paulo por conta da rapidez com que os veículos são conduzidos a

\footnotetext{
${ }^{8}$ A expressão "literatura menor", usada por Deleuze e Guattari, tem o propósito de valorizar a escrita sincrética construída pelas minorias. A expressão reverte o julgamento convencional entre cânone e margens, uma vez que atribui grande importância à contaminação das "línguas maiores" por falares estrangeiros, regionais, dialetais.
} 
partir das estrofes que se seguem: "Não quero que ninguém passe /Neste núcleo o que eu passei/ Que não entre neste falso/ Paraíso onde eu entrei. /Eu andava toda trapuda / como um judas pelas ruas da cidade./ Eu estava vasculhando, / procurando a dona felicidade." (DE JESUS, 1996, p. 214.).

As estrofes em redondilhas justificam a decepção da voz que se expressa (eu lírico) com a cidade. São Paulo passa a ser mais do que a falta de liberdade de se poder andar despreocupado, o local é considerado ilusão, "falso paraíso". A expansão das fábricas e o aumento da necessidade de mão-de-obra fizeram com que muitos brasileiros trocassem o campo pela cidade. O êxodo rural no Brasil adquire consistência nas décadas de 1950 e 1960. A falsa ideia de melhoria das condições de vida atraiu inúmeros brasileiros para os centros urbanos. As consequências foram o aumento de moradias precárias, fome, desemprego. Muitos não se acostumavam com o ritmo da cidade. A rapidez e o egoísmo dos motoristas marcam o incômodo, a insatisfação: "Um caipira", visitando a cidade de São Paulo e não podendo andar livremente pelas ruas, disse: "Eu não gosto de São Paulo! / Eu vou dizer qual é a razão / É que o raio destes chauffers / Não são firmes na direção./ Outro dia quase que fiquei / Por debaixo de um caminhão. /Eles andam pelas vias / Parecendo um furacão." ( p. 214.) A sensação de não estar em sintonia com o espaço é vista ainda em "Eu aqui nesta cidade/Não tenho tranquilidade/Corro mais do que um veado/ Tenho que tomar cuidado/ Para não ser atropelado."

Em um momento de crescente industrialização no país, os automóveis denotam prosperidade e conferem o caráter de pleno desenvolvimento à cidade. No entanto, os mais pobres, em busca da sobrevivência, disputam espaço com os automóveis. Em relação à busca pela melhoria de vida, o poema revela: "Ela é muito poderosa / (A dona felicidade)/ E orgulhosa / Tem fobia dos homens pobres / Gosta de bajular/ E auxiliar... Os nobres." (p. 215.) Ao finalizar o poema, um lamento. A ideia de que a cidade é uma ilusão, reduto de tristeza e sofrimento. São Paulo é encarada como um lugar para poucos, um espaço de privilégios e ao mesmo tempo de dor e angústias. "Que luta! Que estertor!/ Quem em vida o homem sente / Quem mais sofre é o escritor, / Quando morre interiormente. / Entrei no meio deste povo. / E fiquei tão desiludida / A única coisa que eles fizeram/ Foi complicar a minha vida. ( p. 216).

Os espaços se fazem muito presentes nos textos de Carolina. A autora cria metáforas para demarcar os limites entre um universo e outro. A linha geográfica é geralmente tênue, mas é o valor simbólico atribuído pela sociedade ao espaço; as questões de acessibilidade, mobilidade e serviços é que tornam essas diferenças marcantes. Nem sempre, no trabalho da autora, São Paulo é vista de modo negativo. Em Quarto de despejo, ela estabelece uma detalhada divisão dos núcleos da cidade: 
“(...) Eu classifico São Paulo assim: O Palácio, é a sala de visita. A Prefeitura é a sala de jantar e a cidade é o jardim. E a favela é o quintal onde jogam os lixos". (DE JESUS, data, p. --) Há uma metáfora clara para distinguir a favela da cidade, como se um espaço não estivesse inserido no outro. Carolina, na mesma obra, enfatiza ainda que: "Quando estou na cidade tenho a impressão que estou na sala de visita com seus lustres de cristais, seus tapetes de veludo, almofadas de cetim. E quando estou na favela tenho a impressão que sou um objeto fora de uso, digno de estar num quarto de despejo" (p. 56).

Para a escritora, a favela, mesmo pertencendo ao território geográfico da cidade de São Paulo, não se encaixa nos critérios de qualidade que infundem respeito. Em Quarto de despejo, a luta da escritora pela melhoria de vida e suas metas enquanto artista estão atreladas a um projeto distante da favela do Canindé, pois "que realidade amarga! Eu não residia na cidade. Estava na favela ". Mas Carolina não só queria deixar aquele ambiente, como também almejava o fim daqueles espaços. "Espero que os políticos estinguem as favelas"(p. --). No momento histórico vivido por Carolina, as favelas eram insalubres. "As oito e meia da noite eu já estava na favela respirando o odor dos excrementos que mescla com barro podre."(p. --)

É preciso considerar que diante das dificuldades enfrentadas, Carolina não tinha motivos para vislumbrar uma favela positiva, como espaço criativo, de resistência cultural. Não via razões para ter orgulho. Inaugurando a questão das poéticas sobre São Paulo, o poema de Carolina traz a figura de um caipira que se sente incomodado com a velocidade dos automóveis na cidade. Ferréz inicia seu conto intitulado "O plano" discorrendo sobre a questão do transporte público na vida do trabalhador paulistano, "o trampo nem cansa muito, o que mais condena o trabalhador é o transporte coletivo."(p. --) O autor relaciona as mazelas sofridas pelos pobres ao que ele chama de "plano". "(...) o ônibus balança que só a porra, tenho até desgosto de continuar a escrever, mas comigo o plano não funciona"(p. --).

$\mathrm{Na}$ visão de Ferréz, a falta de capacidade crítica, a desinformação e alienação seriam administradas pelos mais ricos e difundidas principalmente pela mídia, em especial pela televisão. Assim como Carolina que problematiza a falta de estrutura nas favelas, Ferréz menciona que: "morar em periferia sempre me prejudicou, esgoto, bebedeira, tiro, e principalmente para se candidatar a algum emprego. É do Capão? Então não emprega" (p.--). O Capão Redondo é uma região pobre da cidade de São Paulo, repleto de favelas e problemas estruturais.

Assim como Carolina que, na década de 1950, enfrentava o preconceito e a discriminação por conta de sua situação social, Ferréz buscou na literatura uma possibilidade para "desabafos" - como ele mesmo afirma. Em "O plano", fomenta uma 
discussão com outro escritor paulista, Marcelo Mirisola, na qual declara que "hoje a quebrada é usada contra mim, por mulheres como a Marisola, que acha que a vida do escritor é que o define, polêmico, saiba que o Leão é mais importante que a fauna, mas pensando bem vou falar de gente." (p. 32 )

A desconfiança do mérito e a crítica ao engajamento de Ferréz em sua comunidade foram deslegitimadas por Mirisola em diversas entrevistas. de sua parte, o escritor aborda "o plano" e diz que ele vem dando certo, surtindo efeitos. "NINGUÉM É INOCENTE EM SÃO PAULO. Somos todos culpados. Culpados. Culpados também". (p. 28) A revolta com a mídia e os ataques ao sistema resultam no tom de provocação de seu texto. "O mundo em guerra e a revista Época põe o Bambam do Big Brother na capa, mas que porra de país é este? O mesmo país que se dizima com armas de fogo e as mantém pelo referendo. Ah! É verdade, o plano funciona". (p. 28)

A agenda midiática de prioridades não se importa com as reais demandas da população. $O$ autor questiona a invisibilidade das questões sociais, a negligência em face à luta cotidiana do pobre para cumprir sua jornada de trabalho. Enquanto Carolina combina palavras agressivas e cria metáforas poéticas para decodificar seu universo, Ferréz é ácido, "desabafa", "manda recados" aos seus oponentes. A cidade de São Paulo concentra desigualdades por conta do "plano". "O plano vai bem, dois manos de cadeira de rodas no final da Capelinha, um outro de muleta, um cego entra logo depois, essa porra é ou não é uma guerra? Os pés descalços, sujos como a mente da elite, o plano vai bem, todos resignados, cada um, uma sequela, chamados desgraçados, nunca têm no bolso o dobro de cinco". (FERRÉZ, 2006, p. 29).O título do livro de Ferréz, Ninguém é inocente em São Paulo, possui uma ilustração que representa a ideia de "plano" concebida por ele. A imagem retrata a desigualdade e ao mesmo tempo a coexistência de dois espaços tão distintos socialmente, separados por uma frágil mureta.

A fragilidade da mureta é símbolo da culpa demonstrada pelo autor: todos somos culpados porque permitimos a segregação por mecanismos vulneráveis, porque compramos o entretenimento sem qualquer critério crítico, e porque fomentamos a mídia, não questionamos, vendendo barato nossa consciência. Por isso não há inocentes na cidade de São Paulo, nós sustentamos o sistema tal qual ele é. Refletir sobre a problemática de São Paulo, seja na década de 1950 ou nos anos 2000, é lidar com desigualdade, projetos de vida negligenciados. Problematizar o papel da literatura na escrita de Carolina e Ferrez é buscar meios de compreensão que dialoguem com atmosferas distintas e ao mesmo tempo próximas tematicamente. O transeunte dos anos 2000 ainda se sente aprisionado, não podendo andar livremente pelas ruas de São Paulo, assim como o caipira descrito por Carolina. A falta 
de liberdade está nas longas horas dentro do transporte público somadas às fatigantes horas de trabalho. "Não tenho tranquilidade (DE JESSUS, 1996, p. 49) - afirma o caipira. "O que mais condena o trabalhador é o transporte coletivo"(p. 28) - diz Ferréz. Sendo assim, mesmo que por abordagens diferentes, Carolina e Ferréz são escritores que ajudaram/ajudam no trabalho poético de questionamento da ordem vigente, problematizando o mundo, enfrentando a vida.

A grande questão é que do Canindé ao Capão Redondo as formas de se expressar foram transformadas no sentido de possibilitarem maior amplitude e visibilidade dos conteúdos abordados, já que a literatura marginal/periférica conquistou espaços e formou por si só um sistema de circulação em meios hegemônicos e também não hegemônicos. Conforme representado na fotografia, assim como o muro que divide os abastados dos favelados, uma linha cada vez mais tênue divide a literatura burguesa da periférica.

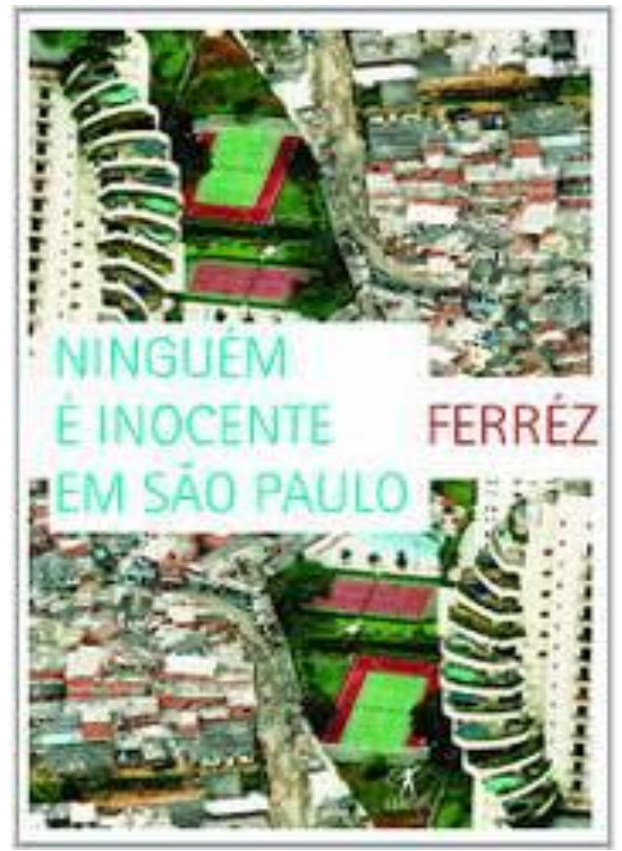

Figura 1 - Capa do livro de Ferréz

Assim, na favela do Candindé de 1950 ou no Capão Redondo dos anos 2000, nos registros poéticos de Carolina ou na prosa direta e incisiva de Ferréz, o racismo e a pobreza são enfatizados como obstáculos que tornam a vida mais dura para os poetas, é uma realidade de fomento e tragédia. Os anos se passam e a periferia, enquanto espaço simbólico, continua a ser dos pobres e pretos, seja em relação à moradia ou como representatividade política e artística. Por isso se faz importante não esquecer dos que ousaram escrever quando não Ihes era permito, dos que não 
desistiram mesmo diante das constantes negativas e dos que vislumbram um projeto literário potente, feito na periferia e distribuído amplamente. Escrever, expressar e valorizar a cultura negra, o povo da favela, e suas tradições é uma forma de contraporse a todos os pífios argumentos inseridos na coluna do jornal O Globo de 1944. Argumentos esses que adquiriram uma roupagem diferenciada, mas não deixaram de ter seu lugar no discurso de parcela privilegiada da população brasileira.

\section{2}

\section{Terrorismo literário}

Conforme citado anteriormente, "Terrorismo Literário" é o texto de abertura de uma coletânea organizada por Ferréz. O texto recebe esse título porque o autor o entende como uma desestabilização do contexto literário até então vigente. E ele estava certo, a coletânea de textos de autores da periferia, publicados na revista Caros Amigos e sua posterior compilação em forma de livro é um marco na literatura brasileira. Mas antes dos anos 2000, é possível considerar o trabalho de Carolina e, aí, é importante pensar no seu trabalho como um divisor de águas também. O impacto do trabalho de Carolina na década de 1950 pode ser relativizado, uma vez que sua leitura pautou-se por equívocos, hoje reconhecidos, que contestavam seu valor artístico-pensante, por atribuírem-lhe apenas interesse sociológico. Porém, é importante atentar para o peso do trabalho de Carolina no panorama literário atual. No passado, sua literatura, ao ser lançada, teve o papel importante de desestabilizar, instaurar o "terror", conforme dito por Ferréz. Mulher negra que trazia um relato curioso sobre suas experiências de favelada, Carolina causou certo furor também por vender significativa quantidade de livros em poucas semanas. Como mecanismo de coesão e preservação das tradições, o universo literário a tratou com arrogância, focando atenção na escrita afastada da norma culta, investigando sua vida pessoal, tratando-a como uma favelada, termo pejorativo para defini-la. A audácia de Carolina foi escrever livros.. Mas antes do lançamento de Quarto de despejo, o Jornal do Brasil já noticiava o trabalho. Na edição de 20 de Junho era possível ler:

(...) A Livraria Francisco Alves está agitando os meios editoriais brasileiros. Nas suas duas coleções Alvorada e Terra Forte, a editora tem lançado sistematicamente autores novos. Proximamente editará Laços de família, de Clarice Lispector, e, em agosto, inaugurando nova coleção, Contrastes e Confrontos, será lançado o diário da favelada Carolina Maria de Jesus, com apresentação de Audálio Dantas, Quarto de despejo (...)

(Jornal do Brasil. 25/06/60 - Edição 00148) 
É possível perceber que a matéria do Jornal do Brasil anuncia a nova autora de forma pouco convencional. Parece que a expressão "escritora", na matéria do Jornal do Brasil, por estar próxima de Clarice Lispector não serve para qualificar Carolina, já que o vocábulo "favelada" antecede seu nome. É uma escolha que o jornal fez para representar o novo nome no mercado editorial. E o atributo de favelada the rendeu mais notoriedade do que seu trabalho literário em si. Em uma pesquisa simples na Hemeroteca da Biblioteca Nacional, buscando somente informações sobre Carolina Maria de Jesus no Jornal do Brasil, a partir da década de 1960, período de lançamento e maior número de vendas de Quarto de despejo, confirma-se que a autora, em diversas notícias, era apresentada como catadora e favelada.

\begin{abstract}
São Paulo lança escritora negra: Carolina Maria. Quarto de Despejo é o livro escrito pela favelada Carolina Maria de Jesus, de São Paulo, e lançado na semana atrasada, batendo, de saída o recorde de venda em tardes de autógrafos: Carolina foi apresentada ao público pela livraria Francisco Alves, vendendo 600 exemplares de Quarto de Despejo, no primeiro dia (...)
\end{abstract}

(Revista de Domingo, Jornal do Brasil. 28/08/60 - Edição 00196)

É possível observar que, mais uma vez, Carolina recebe o título de escritora na chamada da matéria mas, em seguida, o atributo mais próximo que a qualifica é o de favelada. Faz-se necessário salientar que, apesar de inúmeras matérias reducionistas sobre a capacidade da autora em realmente fazer literatura, Carolina obteve relativo sucesso também por estar sempre em destaque nos meios de comunicação do período.

Stuart Hall trata da importância da "diferença" a partir de quatro perspectivas: linguística, social, cultural e psíquica. Para compreender a representação de Carolina enquanto alteridade nos meios de comunicação, enquanto "outro", figura que destoa do universo literário daquele momento, majoritariamente masculino, branco e burguês, é preciso pensar as possibilidades e os atributos teóricos do conceito de "diferença" na concepção desse pensador. Stuart Hall afirma que a "diferença" é sempre um conceito ambivalente, isto porque, se, por um lado, é necessário para a produção de significados para a formação de identidades, por outro, é ao mesmo tempo ameaçador, local de perigo, de sentimentos negativos. Segundo Hall:

O argumento aqui é que o "Outro" é fundamental para a constituição do self dos sujeitos e para a identidade sexual. (...) Nossa subjetividade é formada por este diálogo problemático, nunca concluído e inconscientemente com o "Outro" - com a internalização do "Outro". É formada em relação a algo que nos completa, mas que - por se encontrar fora de nós -, de certa forma, sempre nos falta. (...) Frantz 
Fanon (1986 [1952]) usou a teoria psicanalítica em sua explicação para o racismo, argumentando que a maioria da estereotipagem racial e a violência surgiram a partir da recusa do "Outro" branco em reconhecer "do ponto de vista do outro" a pessoa negra.

(HALL, 2016, p. 45)

Um exemplo bastante pedagógico nesse sentido é a exemplificação trazida por Liv Sovik em seu livro Aqui ninguém é branco. Ao analisar a repercussão midiática do dramático caso de Sandro, rapaz negro que assaltou o ônibus 174, Liv Sovik estabelece uma conexão entre a figura de Sandro e o "estranho familiar" de Freud, uma figura cuja incerteza em torno da humanidade traz à tona o quanto o medo e a familiaridade podem coexistir. O negro pode ser interpretado como quase-eu, já que há intolerância de uma semelhança excessiva, de uma humanidade comum.

Carolina pode ser lida como uma mulher que superou barreiras concretas de classe, gênero e raça. A desqualificação de seu trabalho é perceptível em algumas formas como a escritora é representada. Além da insistência do discurso jornalístico em identificá-las como favelada, algumas fotografias da escritora expõem a questão da problemática da representação positiva ou negativa, vista a partir da perspectiva de Staurt Hall.

Comparem-se duas fotos de Carolina Maria de Jesus. Na primeira, ela aprece sentada em sua mesa, fazendo sua habitual leitura. A foto mostra um ambiente simples, onde tábuas fazem as vezes de móveis, e a escritora parece lançar um olhar sereno para o texto que estava lendo. Na segunda figura, aparece Carolina, em postura adequada para sua noite de autógrafos, na Livraria Francisco Alves.

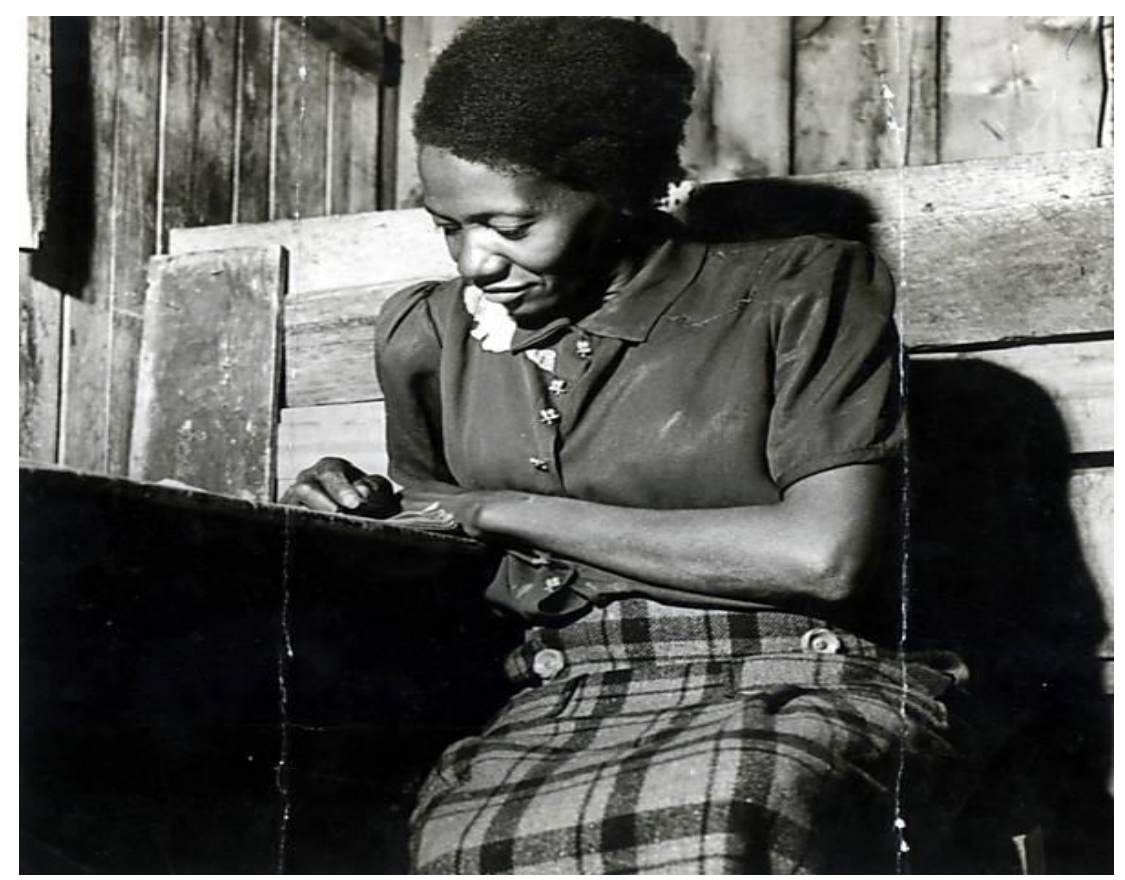

Figura 2 - Carolina em sua casa 


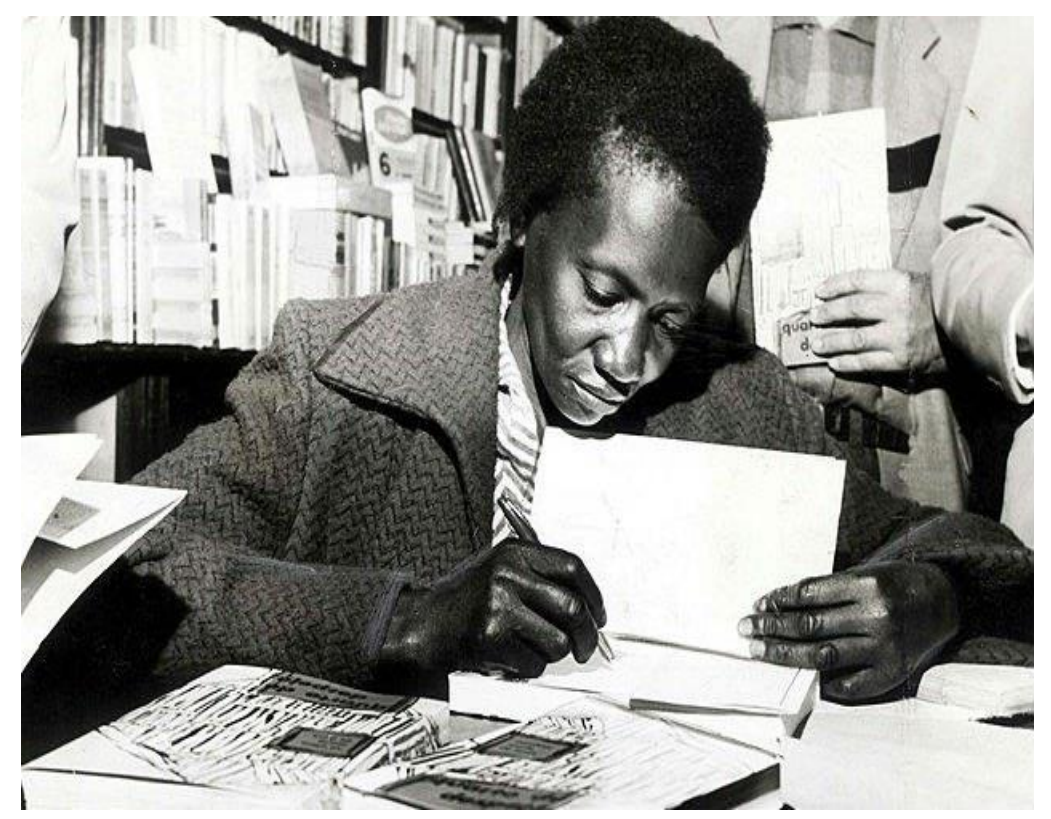

Figura 3 - Carolina em noite de autógrafos

Essas fotografias ilustram o que Stuart Hall estabelece ao tratar do problema da estratégia do positivo/negativo no tocante a representação da alteridade. 0 sociólogo afirma que embora as iniciativas de adicionar imagens positivas sejam estratégias que ampliam a diversidade com que "ser negro" é representado, “(...) o aspecto negativo não é necessariamente deslocado. Já que os binários não foram deslocados, o significado continua a ser enquadrado por eles. A estratégia desafia os binários - mas isso não os prejudica". (HALL, 2016, P. 28) A beleza da foto de Carolina é única, mostra seu olhar sereno, sua feição alegre, sua negritude. Mas, na lógica descrita por Stuart Hall, ela pode ter uma leitura que reforce estereótipos racistas, uma vez que toda significação de uma representação parte dos critérios específicos de uma sociedade, uma cultura.

A partir das fotografias que apresentam Carolina Maria de Jesus como escritora, seja em seu momento íntimo de leitura, ou na noite de lançamento de seu livro, é possível ponderar que a questão da representação a partir de uma perspectiva política que valorize a diversidade é um tema complexo que exige esforço de compreensão e revisão. Uma alternativa à questão de positivar a representação do negro é "ler" positivamente o elemento negativo. Os Movimentos Negros fazem isso quando empregam o termo "denegrir", transformando um uso socialmente pejorativo, relacionado a ferir a honra, degradar uma imagem em um reforço positivo de que ser negro. Afirmam a potência advinda de tornar-se negro.

Vale destacar que foi publicada, porém, no caderno B, do Jornal do Brasil, uma matéria curiosa e bastante preconceituosa em relação às habilidades da escritora. 
Um caso: - A moça, de aparência modesta, chegou na redação, procurou o colunista e, abrindo uma sacola de compras, tirou um livro, explicando que viera de Brasília para entregá-lo pessoalmente no Rio. Não se identificara como a autora senão quando se propôs a conceder um autógrafo, retirando-se em seguida com a seguinte informação: "São impressões de uma doméstica nas casas por onde andou". O livro chama-se Quero casar, ora se quero, foi editado pela Ebrasa (Editora de Brasília) e seu conteúdo tem um tom mais grave do que sugere o título superficial. A autora, Teresa Macena, não é uma Carolina Maria de Jesus: escreve corretamente. Pedimos que a autora voltasse à redação para fornecer maiores subsídios sobre seu livro.

(Caderno B, Jornal do Brasil, 09/10/69 - Edição 00158)

Com a afirmação -- "A autora, Teresa Macena, não é uma Carolina Maria de Jesus: escreve corretamente"--, Carolina é tratada na coluna como um mau exemplo, uma vez que não escreve de acordo com as normas gramaticais vigentes. Seu nome é invocado apenas para a desqualificação de seu trabalho, quase 10 anos após o primeiro e mais vendido livro de Carolina, Quarto de despejo. As estratégias de silenciamento e invisibilização são inúmeras, o Brasil apresenta um tipo de racismo pautado em um acordo tácito em que vigoram os parâmetros da branquitude. $O$ discurso da mestiçagem é outra armadilha ideológica que suprime os não brancos e seus legados culturais. O meio literário, apesar da grande tendência de descentralização de narrativas conquistadas no final do século $X X$ e início do XXI, ainda se apresenta como um universo avesso à heterogeneidade.

A ascensão de uma perspectiva cultural ressignifica as manifestações artísticas não só no campo da literatura, mas das artes como um todo. É essa ascensão que cria a tensão existente entre duas perspectivas literárias: a que privilegia um critério conservador de forma, uma estética estabelecida pelo gosto da elite, e a que, influenciada pela guinada cultural, interpreta a literatura como uma manifestação própria da sociedade, fruto de um tempo histórico e que portanto deve ser estudada de acordo com as referências (populares, híbridas, revolucionárias) desse contexto. É importante ressaltar que não há como se desvencilhar da concepção de que a literatura é, sim, fruto de seu contexto histórico e cultural que constitui seus critérios estéticos.

\section{3}

\section{Moradas}

"Morada", no dicionário, significa casa de habitação, lugar onde se mora ou permanece, lugar em que uma coisa está habitualmente. É também o título do livro 
composto em parceria por Allan Santos da Rosa e Leonardo Martins Galina, também conhecido como Guma. Trata-se de um livro de fotografias tiradas por Guma e suplementadas por textos poéticos elaborados por Allan. Como lembra o próprio Allan da Rosa: "O livro é de fotos. Texto é mero convidado"( GUMA \& ROSA, data, p. --). No entanto, podemos perceber que o texto estabelece um precioso diálogo com as imagens, trazendo outras dimensões significativas ao leitor.

Em uma apresentação amistosa e atrativa, o leitor é convidado a entrar, a participar daquele universo. A "morada" do pobre é costumeiramente vista de fora para dentro, é através do olhar de pesquisadores e outros curiosos que a casa é mostrada. Marcelino Freire, no conto intitulado "Solar dos príncipes", explora a questão do olhar em relação à casa através da seguinte observação:

\begin{abstract}
"A gente abre as nossas portas, mostra as nossas panelas (...) O morro tá lá, aberto 24 horas. A gente dá as boas-vindas de peito aberto. Os malandrões entram, tocam no nosso passado. A gente se abre que nem passarinho manso. A gente desabafa que nem papagaio. A gente canta, rebola. A gente oferece a nossa coca-cola".
\end{abstract}

(FREIRE, 2014, p. 27)

O título escolhido por Marcelino, "Solar dos Príncipes", assinala justamente essa visão preconceituosa, existente em relação à habitação, que marca a diferença de classe. O "Solar dos príncipes", ao que tudo indica no conto, é apenas um condomínio de classe média. Três jovens que se dispõem a fazer a investigação sociocultural da região, têm o acesso negado logo na portaria, onde se concentra toda a narrativa e se desdobra o imbróglio. O racismo é o primeiro impedimento à pesquisa dos jovens, já que eles não conseguem cruzar o limite de entrada do prédio. A "triagem" é feita pelo próprio porteiro, que também é negro, mas cumpre seu papel ao identificar as possíveis "ameaças" ao bem-estar dos moradores. O desfecho do conto reforça a ideia de que a "morada" do pobre é acessível e está sempre disponível aos olhares de quem esteja disposto a conhecê-la, mesmo que esses olhares sejam estigmatizantes e reducionistas. "Solar dos príncipes" corrobora a ideia de que a acessibilidade não é uma via de mão-dupla, destacando em seu título a ideia de que a morada dos não pobres é de difícil acesso, super vigiada e equipada com itens de segurança.

"A gente dá as boas-vindas de peito aberto", conforme a fala de um dos integrantes do trio que quer investigar as moradas fora da favela. De acordo com o apresentado em Morada, a casa é o "maior grão de sonho de qualquer trabalhador", ou seja, é uma conquista, é o que permanece, é o "cazuá" que recolhe o cansaço, é um ambiente sagrado, de interação, trabalho e afeto. É a busca por referências 
diferentes das experienciadas pelos moradores de periferias que levam os jovens pesquisadores de "Solar dos príncipes" a pressuporem que a assimétrica relação entre classes pode ser superada em prol de uma reciprocidade em torno da temática 'habitação'.

Gaston Bachelard, em seu estudo fenomenológico intitulado $A$ poética do espaço afirma que "(...) a casa é nosso canto no mundo. Ela é, como se diz frequentemente, nosso primeiro universo. É um verdadeiro cosmos. Um cosmos em toda a acepção do termo. Até a mais modesta habitação, vista intimamente, é bela (...)" (BACHELARD, 2000, p. 201). Assim, a casa da periferia, para além de uma conquista e um motivo de orgulho, na construção artística de Allan da Rosa e Guma, representa uma força ancestral, é "guarida, alento", é o lugar de resistência onde o mateiro inicialmente campeou e se abrigou. A morada é, portanto, um importante lugar de inserção no mundo capaz de orientar e promover nossos maiores devaneios, anseios e projeções sociais.

Carolina Maria de Jesus estabelece ao longo de sua vida reflexões significativas em relação à moradia e o impacto desse aspecto em sua existência. Bachelard discorre sobre a imagem da casa e como ela proporciona um verdadeiro princípio de integração psicológica e afetiva. Mesmo que a autora registrasse, no diário, sua constante insatisfação com o lugar de moradia, a que teve de submeter-se, e as mazelas pelas quais passava, em passagens de Quarto de despejo, Carolina fala de seu rádio e seus livros com entusiasmo e orgulho. A arte e a possibilidade de se expressar livremente motivam-na e inspira-na, é a arte o lugar de conforto e aconchego, é por meio da linguagem que Carolina estabelece "seu canto no mundo", conforme considera Bachelard. A autora consegue mesclar momentos dramáticos e poéticos, utilizando recursos metafóricos, irônicos, paradoxais, valendo-se de experiências sensoriais que incrementam poeticamente seu cotidiano: “(...) $\mathrm{Na}$ casa de D. Neném o cheiro da comida era tão agradável que as lágrimas emanavam de meus olhos (...)" (DE JESUS, 2005, p. 94).

A metáfora mais famosa, cunhada pela escritora, dá nome ao seu livro mais reconhecido. Quarto de despejo é assim denominado justamente por Carolina estabelecer que a favela era o quintal onde se amontoavam os dejetos de São Paulo: “(...) Eu classifico São Paulo assim: O Palácio, é a sala de visita. A Prefeitura é a sala de jantar e a cidade é o jardim. E a favela é o quintal onde todos jogam lixo.(...)E quando estou na favela tenho a impressão que sou um objeto fora de uso, digno de estar num quarto de despejo"(DE JESUS, 2005, p. 32). As comparações a partir do eixo moradia são recorrentes nos trabalhos de Carolina. Depois de lançar Quarto de despejo, Carolina escreve seu segundo livro intitulado Casa de alvenaria, que também 
se enquadra no gênero diário. Nele, a autora narra seus dias a partir da repercussão e sucesso de seu primeiro trabalho, já residente em uma casa de alvenaria, longe da favela e da vida de catadora de papel.

Mesmo que Quarto de despejo tenha sido reconhecido por denúncias e relatos chocantes de experiências de caos e escassez, é urgente notar que Carolina, em diversas passagens, utiliza a linguagem como mecanismo expressivo fazendo uso de trechos poéticos como "Os pardais já estão iniciando a sua sinfonia matinal (...)"(p.67) e até mesmo manifestando seu viés romântico como exposto em:

(...) Contemplava extasiada o céu cor de anil. E eu fiquei compreendendo que eu adoro o meu Brasil. O meu olhar posou nos arvoredos que existe no inicio da rua Pedro Vicente. As folhas moviase. Pensei: elas estão aplaudindo este meu gesto de amor a minha Pátria. (...) Toquei o carrinho e fui buscar mais papeis. A Vera ia sorrindo. E eu pensei no Casemiro de Abreu, que disse: "Ri criança. A vida é bela".

(DE JESUS, 2005, p.66)

Carolina seguia seu propósito de ser uma escritora reconhecida e evidenciava seus inspiradores, no caso em questão, o importante poeta romântico Casimiro de Abreu. A natureza sempre fez parte do repertório, se sua casa não era um ponto de aconchego, um porto seguro, ela tinha na paisagem natural os recursos necessários para elaborar sua linguagem poética. A par de sua escrita lírica, Carolina não abria mão de críticas e queixas em relação à favela em que residia. Registrava seu descontentamento com o espaço social em que estava inserida: "Os vizinhos de alvenaria olha os favelados com repugnância. Percebo seus olhares de ódio porque eles não quer a favela aqui. Que a favela deturpou o bairro. Que tem nojo da pobreza."(p.67-) A escritora diz ainda que "Percebo que todas as pessoas que residem na favela, não aprecia o lugar"(p. 69).

Entre as perspectivas de Carolina Maria de Jesus e Allan da Rosa, observamos que são olhares que se distanciam por conta do tempo e de suas subjetividades próprias. Como já se observou, mais no início do capítulo, faz parte da estratégia da literatura periférica atual, reverter a imagem estigmatizada da favela. Morada é um exemplo eloquente dessa iniciativa, pois valoriza as atividades das pessoas que residem naqueles espaços e procuram ressignificá-lo. Esse olhar de afetividade, que destaca o cuidado de cada morador com sua casa, no entanto, não esconde a precariedade dos serviços públicos, disponibilizados na vizinhança. Allan da Rosa dá conta das dificuldades: 
(...) é a zonzeira e o necrotério dos pronto-socorros, açougues de avental branco, com três vigias pra cada médico. É tremer a bela chuva, com esgoto transbordando e se exalando, se convidando pra visitar o mocó. O bueiro metralhando as narinas. Há quem chegue a passar o papel higiênico no ar, querendo limpar a brisa. Córguinhos: a saliva cariada da cidade. Aluga alaga aluga alaga. Tábua, tomba, tauba, taba.(ROSA; GUMA, 2007, s/p).

É na escrita poética que Allan da Rosa e Carolina Maria de Jesus, apesar de toda a distância cronológica e estilística, se aproximam. É no bueiro que não exala o cheiro ruim, mas que "metralha as narinas", estabelecendo um paralelo com a violência local, que Allan denuncia poeticamente a presença cotidiana das armas, seja por causa do tráfico ou do uso abusivo das forças policiais; bem como o abandono do poder público em relação ao saneamento básico. Carolina se emociona ao sentir o cheiro da comida de sua vizinha e através dessa experiência sensorial, denuncia a fome. Allan da Rosa estabelece um importante paralelo entre Poesia e Morada. A poesia estabelece relação metafórica com o trabalho de ser escritor:

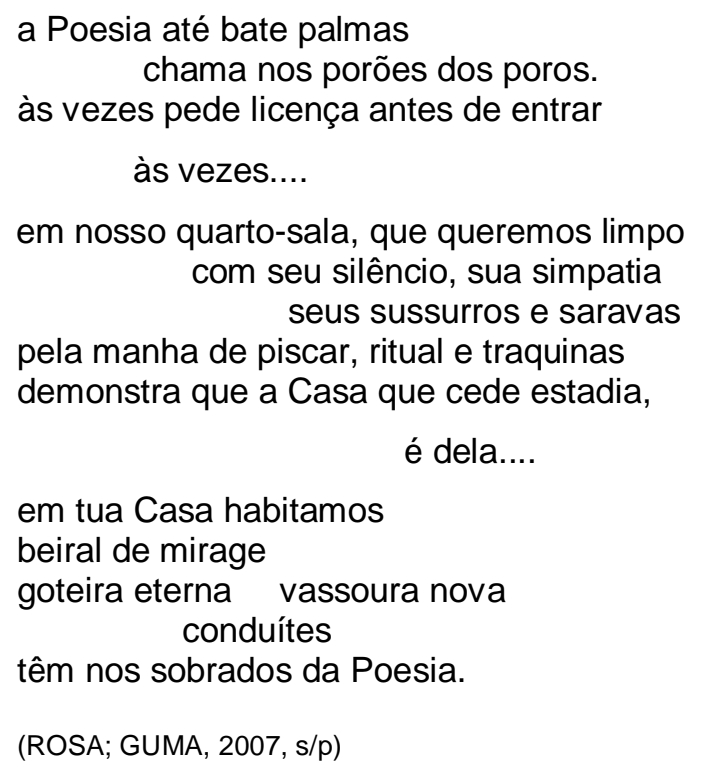

A Poesia com letra maiúscula, no poema, demonstra uma caracterização potente e imponente. É a mesma que pode ser confundida com um velho conhecido que chama, bate palmas na intenção de interagir com o dono da casa, já que sequer pede licença. O poeta é a casa da poesia, e essa é a principal morada em questão, seja no trabalho de Allan da Rosa, seja na escrita de Carolina Maria de Jesus. O poeta é o quarto-sala limpo, silencioso que evoca seu caráter ancestral. Por seu lado, a Casa pertence à poesia e há o convívio mútuo entre elas, já que "em tua Casa habitamos" (p.23).

O trabalho de Moradas retrata justamente um plano intimista e autoral que trata das relações dos moradores com suas residências, trazendo expressivamente os pequenos gestos, cuidados e afetos característicos daquela organização. Assim, para 
além das paisagens interiores, também estão os registros dos becos, das passagens e das vielas tão presentes nas periferias brasileiras. A fotografia mais emblemática, que inclusive é a fotografia que ilustra a capa, demonstra uma decoração cuidadosa, colorida e aconchegante. Ali também está a poesia, nos detalhes, no zelo, na combinação.

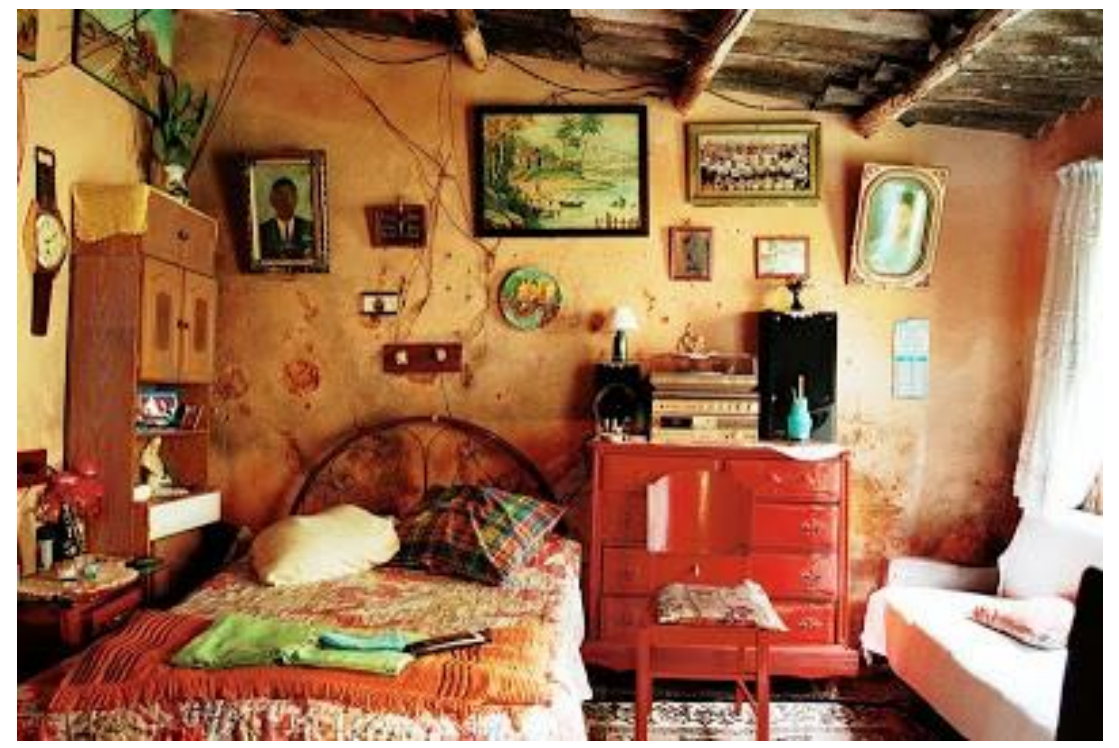

Figura 4 - Foto de Guma

A poesia de Allan da Rosa se mescla com o olhar atento da fotografia de Guma e juntos trazem à tona o cotidiano dos moradores de periferia. Escrita e imagem lançam um olhar diferenciado para essa realidade, tratando a questão para além dos clichês fixados nas carências do espaço. Imagem e texto evocam a persistência, a união e a criatividade para burlar a falta de estruturas básicas. É possível perceber zelo, senso estético de combinação de tons e cores. A foto acima reproduzida capta a essência do trabalho de Morada. A casa, mesmo marcada por certa precariedade material, busca suprir essas necessidades por um tratamento colhedor do espaço. A "morada" de Carolina se dá por meio da tessitura de sua linguagem, é seu estilo que garante a potência artístico-crítica de seu trabalho, mesmo estando afastado das convenções gramaticais. São os detalhes, o capricho, os recursos estilísticos da autora que caracterizam sua poesia.

A casa é também, por vezes, o lugar do trabalho, o lugar que traz o sustento. Como diz Allan da Rosa, "Casa: onde se lida a vida, onde a máquina de costura adentra as madrugadas no fura-dedos, na engenharia da tecelagem, na teia das linhas que germinam vestes." (p. --) Carolina tem também em sua residência o espaço para a feitura de seu trabalho. Depois de um dia intenso, ela encontra sua liberdade na escrita, onde constrói seu pensamento. A fotografia de Guma retrata o ofício manual 
da costura, que não se distancia do ofício manual e também solitário da escrita. A palavra texto tem origem latina, texere, seu significado vem de construir, tecer. O ofício da escrita é também o de tessitura e apresenta o mesmo significado de tecelagem, no sentido de construir uma estrutura.

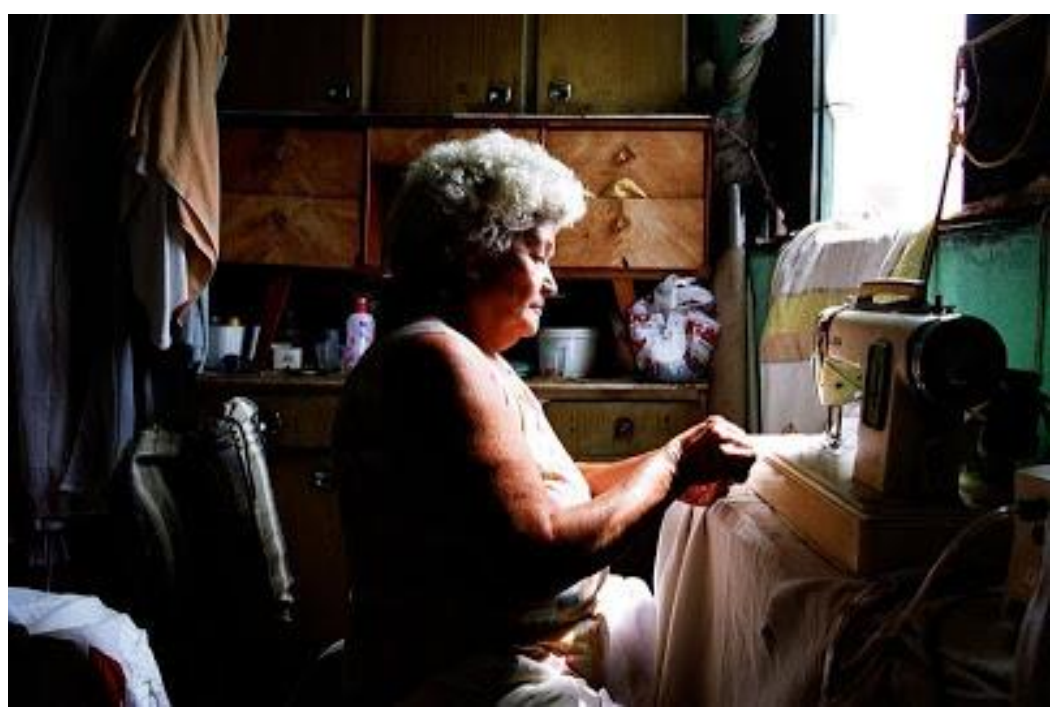

Figura 5 - Foto de Guma

A sensibilidade do olhar, o gesto, o zelo artesão fazem da poesia, seja ela manifesta no cuidado da casa, seja no trato com as palavras, um recurso expressivo valioso no enfrentamento das adversidades que a vida oferece. É possível mais do que sobreviver, é possível ressignificar, criar, imaginar. A arte é a grande possibilitadora da vida, é através do olhar dos poetas, que são a própria morada da poesia, que podemos perceber crítica e esteticamente a beleza do que nos cerca.

\section{4}

\section{Negritude e ancestralidade}

Uma das temáticas presentes no trabalho de Carolina foi a questão da negritude, assunto sempre abordado pela escritora de forma a ressaltar seu orgulho e pertencimento. A exaltação de sua cor e de suas características fizeram parte de obras como Quarto de despejo e Casa de alvenaria, mas nenhum deles abordou a ancestralidade com tamanha exaltação como Diário de Bitita. É nele que a autora fala de suas origens africanas e demonstra todo o amor que a aproxima de seu avô, figura sábia e ancestral que ocupa um lugar especial em sua infância. Como a presente seção segue o viés da releitura, um autor de grande importância na cena literária contemporânea é Sérgio Vaz, que além de escritor, tem papel relevante na atuação 
política de inúmeras comunidades. Ele trata da questão racial de forma diferenciada, propondo algumas subversões.

Sérgio $V z^{9}$, que também é mobilizador cultural das periferias, publicou um texto intitulado "Magia Negra". O cerne de sua temática é a desconstrução de uma acepção preconceituosa das noções de 'magia' e da cor 'negra', amplamente explorada na sociedade brasileira. O termo "Magia Negra" geralmente é atribuído aos praticantes de religiões afro-brasileiras e seu significado é quase sempre pejorativo. Vaz consegue em sua escrita subverter esse sentido.

Magia Negra

Magia negra era o Pelé jogando, Cartola compondo, Milton cantando. Magia negra é o poema de Castro Alves, o samba de Jovelina...

Magia negra é Djavan, Emicida, Mano Brow, Thalma de Freitas, Simonal. Magia negra é Drogba, Fela kuti, Jam. Magia negra é dona Edith recitando no Sarau da Cooperifa. Carolina de Jesus é pura magia negra. Garrincha tinha duas pernas mágicas e negras. James Brow. Milton Santos é pura magia.

Fabiana Cozza, Machado de Assis, James Baldwin, Alice Walker, Nelson Mandela, Tupac, isso é o que chamo de magia negra.

Magia negra é Malcon X, Martin Luther King, Mussum, Zumbi, João Antônio, Candeia e Paulinho da Viola. Usain Bolt, Elza Soares, Sarah Vaughan, Billy Holliday e Nina Simone é magia mais do que negra.

Eu faço magia negra quando danço Fundo de Quintal e Bob Marley.

Cruz e Souza Zózimo, Spike Lee, tudo é magia negra neles.

Umoja, Espírito de Zumbi, Afro Koteban...

É mestre Bimba, é Vai-Vai, é Mangueira todas as escolas transformando quartas-feira de cinza em alegria de primeira.

Magia negra é Sabotage, MV Bill, Anderson Silva.

Pepetela, Ondjaki, Ana Paula Tavares, João Mello... Magia negra.

Magia negra são os brancos que são solidários na luta contra o racismo.

Magia negra é o RAP, O Samba, o Blues, o Rock, Hip Hop de Africabambaataa.

Magia negra é magia que não acaba mais.

É isso e mais um monte de coisa que é magia negra.

$O$ resto é feitiço racista.

(VAZ, 2007, p.15)

Abordar a negritude e discorrer sobre a problemática da representação relacionada a ela é, necessariamente, refletir sobre o viés racista que circunda os espaços hegemônicos de representação. Seja no meio literário, seja nos demais, o Ethos negro é uma questão controversa. Ao tratar de representação sob a perspectiva racializada, Stuart Hall afirma que a tentativa de substituir as imagens "negativas" por

\footnotetext{
${ }^{9}$ Sérgio Vaz é o coordenador do Sarau da Cooperifa que funciona há mais de dez anos em um bar de uma periferia de São Paulo. Esse evento tem grande repercussão na divulgação da poesia das periferias urbanas. A construção coletiva da cena poética atual é contrastante com a situação de isolamento de Carolina.
} 
imagens "positivas" de pessoas negras, de sua vida e cultura tem o mérito de expandir a gama de representações raciais, desafiando assim o reducionismo dos estereótipos.

Ao refletir sobre a temática da representação e o valor da negritude nesse âmbito, é interessante ponderar mais uma vez sobre a representatividade dos negros na história da literatura brasileira. A visibilidade de sua participação é pequena, porém importante. Nomes como Machado de Assis e Lima Barreto figuram entre os mais relevantes autores brasileiros, no entanto, seus componentes étnicos são constantemente ignorados, mesmo que, no caso de Lima Barreto, a questão racial seja tema central em suas obras e que tenha sido motivadora dos dramas de sua biografia. Outro autor negro de destaque no meio literário é o simbolista Cruz e Sousa que, mesmo tendo sua trajetória assinalada pela dificuldade, despontou como um dos mais importantes escritores do Brasil. Mesmo assim, o poeta catarinense Cruz e Sousa foi alvo de campanha racista e difamatória por parte de Araripe Júnior, importante crítico literário do final do século XIX, que não poupou declarações racistas ao comparar a obra Missal, de Cruz e Sousa, ao trabalho de Raul Pompéia, Canções sem metro:

Entre as Canções sem metro e a obra do poeta catarinense, há uma
grande diferença determinada desde logo pela raça e pelo
temperamento de cada um. Raul Pompéia possui a acuidade dos
psicólogos da nova geração e um espírito profundamente inclinado à
filosofia sugestiva, de sorte que os seus escritos aparecem sempre
impregnados disso a que Proudhon chamava l'expression de l'avenir:
tendências tolstoínas para a organização de serviço de salvação da
ideia. Cruz e Sousa, porém, anda em esfera muito diferente. De origem
africana, como já disse, sem mescla de sangue branco ou indígena,
todas as qualidades de sua raça surgem no poeta em interessante luta
com o meio civilizado que é o produto da atividade cerebral de outras
raças. A primeira consequência desse encontro é a sensação da
'maravilha'. Cruz e Sousa é um maravilhado. [...] Ingênuo no meio da
civilização ocidental, para a qual seus antepassados concorreram
apenas com o braço físico, ele olha para tudo com os olhos de um
Epimênides: e todas as suas sensaçães são condicionadas por um
movimento de surpresa que se dilui imediatamente em gestos de
adoração. Imagine-se esse africano na rua do Ouvidor, transportado de
uma cidade pequena e acanhada como é a capital de Santa Catarina.
Tudo nele se transforma em sensações do náufrago de uma raça que,
pelos seus dotes, se encontra iniciado na grande vida e relativamente
acomodado no seio 'harmonioso' (como ele mesmo diz) dessa
deliciosa movimentação."

(MAGALHÃES, 1975, p. 207 e 208)

Um poeta simbolista negro, oriundo da província, era considerado um toque exótico na literatura do século XIX, em que imperavam os parnasianos e sua arte de contornos clássicos. O trabalho de Cruz e Sousa foi desqualificado e desmerecido por conta de sua cor e origem social. Esse legado crítico ainda esbarra na dificuldade de 
escritores negros serem aceitos no meio literário estabelecido e hegemônico. Carolina Maria de Jesus, mulher, negra, marcada por diversos outros estigmas, teve também seu trabalho e sua pessoa, enquanto escritora, desmerecidos e questionados pela crítica da época.

Carolina sabe que vive em uma sociedade racista, passagens de seus livros corroboram a total consciência da autora e, ainda assim, Diário de Bitita segue com a busca de fortalecer sua ancestralidade e reafirmar sua identidade. Mesmo abordando temas espinhosos, ela reitera sua força e faz transparecer sua grandeza. Em Diário de Bitita, é possível ler em um dos diálogos a problematização do tráfico de escravos e a denúncia da situação dos negros num período pós-escravidão:

- Então é você que rouba minhas frutas. Negrinha vagabunda. Negro não presta. Respondi:

-Os brancos também são ladrões porque roubaram os negros da África.

Ela olhou-me com nojo.

-Imagina só se eu ia até a África para trazer vocês... Eu não gosto de macacos.

Eu pensava que a África era a mãe dos pretos. Coitadinha da África que, chegando em casa, não encontrou seus filhos. Deve ter chorado muito.

DE JESUS, 2014, p.58)

A menina Carolina, então Bitita, devolve a acusação de ladra proferida por Dona Faustina, senhora branca, proprietária do terreno que a menina invadiu para colher mangas. Com palavras afiadas e respostas prontas - construídas pela memorialista adulta --, Carolina devolve à senhora a acusação de ladra, fazendo recair sobre a mesma uma transgressão mais grave do que o furto de mangas, o crime de tráfico humano. Ainda discorrendo sobre a disparidade racial no Brasil de sua infância, a narradora afirma, através de Bitita que:

Eu notava que os brancos eram mais tranquilos porque já tinham seus meios de vida. E para os negros, por não ter instrução, a vida era-lhes mais difícil. Quando conseguiam algum trabalho, era exaustivo. O meu avô com setenta e três anos arrancava pedras para os pedreiros fazerem os alicerces das casas.

(DE JESUS, 2014, P.58)

O relato de Carolina é corroborado por estudiosos do período. O importante sociólogo Florestan Fernandes em seu trabalho "A integração do negro na sociedade de classes", afirma que "(...) a sociedade brasileira largou o negro ao seu próprio destino, deitando sobre seus ombros a responsabilidade de reeducar-se e de transformar-se para corresponder aos novos padrões e ideais de homem". Sem garantias, quando da assinatura da Lei Áurea, de qualquer possibilidade de instrução 
ou amparo social àqueles que já tinham sofrido com o regime escravista, a exclusão do negro do cenário social foi consequência direta do processo de abolição da escravidão, como Florestan Fernandes conclui.. "Os senhores foram eximidos da responsabilidade pela manutenção e segurança dos libertos (...) Essas facetas da situação (...) imprimiram à Abolição o caráter de uma espoliação extrema e cruel"(p.49).

Carolina narrou o panorama histórico dos acontecimentos de sua infância com total consciência e lucidez sobre o período. "Quando os pretos falavam: - Nós agora estamos em liberdade. - Eu pensava: Mas que liberdade é essa se eles têm que correr das autoridades como se fossem culpados de crimes?".(DE JESUS, 2014, p. 41) Os questionamentos e angústias de Bitita, oscilam entre o universo infantil, o raciocínio adulto de uma inteligência complexa e perspicaz. A autora lembra ainda a grande tristeza do avô, figura fundamental em sua infância, pela falta de acesso de seus filhos à escola. "Os oito filhos do meu avô não sabiam ler. Trabalhavam nos labores rudimentares. O meu avô tinha desgosto porque seus filhos não aprenderam a ler." (p 39. ) O orgulho da figura ancestral do avô de Carolina se faz presente ao longo da obra Diário de Bitita.

\begin{abstract}
No mês de agosto, quando as noites eram mais quentes, nos agrupávamos ao redor de vovô para ouvi-lo contar os horrores da escravidão. Falava de Palmares, o famoso quilombo em que os negros procuravam refúgio. $O$ chefe era um negro corajoso de nome Zumbi. Que pretendia libertar os pretos. (...) O vovô nos olhava com carinho. 'Deus os protegeu auxiliando-os a não nascer na época da escravidão." Os negros libertos não podiam ficar no mesmo local. Deveriam sair de suas cidades. Uns iam para o estado do Rio, outros para o estado de Minas, de Goiás, para ficarem livres dos xingatórios dos ex-sinhôs, e repetiam as palavras de Castro Alves: "O negro é livre quando morre".
\end{abstract}

(DE JESUS, 2014, p. 62)

As histórias do avô de Carolina, atreladas a sua vivência no período da escravidão, além de dureza e dificuldade, tratavam também de resistência. A figura do avô além de mística, já que Carolina dizia que ele era o único capaz de invocar a chuva, era também heroica. Bitita dizia que "[o] vovô era descendente de africanos. Era filho da última remessa de negros que vieram num navio negreiro. Os negros cabindas, os mais inteligentes e os mais bonitos"(p. --).

Sendo assim, é importante destacar que negritude é entendida aqui como um conjunto dos valores culturais do mundo negro. É a busca por valorizar a história dos afro-brasileiros, despertar o orgulho de pertencimento e questionar os padrões excludentes. Sérgio Vaz afirma a negritude quando reelabora a expressão "magia 
negra", quando enumera figuras de prestígio e as remete ao mundo negro. Carolina Maria de Jesus expõe a importância dos valores da negritude em Diário de Bitita quando questiona o conceito de "liberdade" com o advento da abolição, quando enumera as dificuldades enfrentadas pelos negros no mundo do trabalho, quando apresenta a importante ancestralidade de seu avô, figura decisiva em sua formação.

No tocante à questão da representação, direcionada aqui a partir da perspectiva de Stuart Hall, que define representação como um processo pelo qual membros de uma cultura usam a linguagem para produzir sentido, é de suma importância ressaltar a reflexão do sociólogo jamaicano que afirma:

Desde já, essa definição carrega a importante premissa de que coisas - objetos, pessoas, eventos, no mundo - não possuem, neles mesmos, nenhum sentido fixo, final ou verdadeiro. Somos nós - na sociedade, dentro das culturas humanas - que fazemos as coisas terem sentido, que Ihes damos significados. Sentidos, consequentemente, sempre mudarão, de uma cultura ou período ao outro.

Vale destacar, portanto, que a ruptura proposta em Sérgio Vaz no poema "Magia Negra" só é eficaz no sentido de desfazer um paradigma porque o termo carrega consigo elementos culturais considerados inferiores. Existe um sentido que the é atribuído socialmente. Algo muito similar ocorre com a expressão "chuta que é macumba", ambos os termos menosprezam o universo religioso de matriz africana. Sérgio Vaz rompe com essa representação e ressignifica seu sentido, combatendo o racismo linguístico. O trabalho representativo de Carolina Maria de Jesus também mantém seu significado porque Ihe é atribuído um valor social. Suas experiências, seu lugar de fala garantem a relevância de sua narrativa.

É possível perceber portanto que o trabalho de Carolina não vinha na contramão das articulações dos movimentos negros de seu período, já que a autora aponta para as diferenças sociais existentes e exalta sua negritude, mesmo que não haja registros de que ela frequentasse inicialmente esses espaços da valorização da cultura negra. Posteriormente sim, com a divulgação de Quarto de despejo, Carolina passou a ser convidada por clubes, associações e movimentos de cunho racial de diversas regiões do país, conforme registrado em Casa de alvenaria. Carolina era disputada por lideranças negras, mas não teve nenhum tipo de atuação través dessas associações e movimentos. É possível observar que a literatura de periferia se vale dessa temática, está ligada a essa noção de pertencimento de uma comunidade negra fortalecida, orgulhosa e também rancorosa em relação a seu passado. Nesses grupos, como Cooperifa, Selo do Povo, 1 da Sul dentre outras iniciativas, estão, além da superação da segregação classista, a noção de negritude, já que a maioria dos 
moradores dessas regiões são negros. Seja idealizando suas raízes e distribuindo livros com selos próprios, usando roupas específicas ou criando iniciativas como saraus e batalhas de rap, seja recontando passagens da história brasileira, para resgatara importância daqueles que não tiveram prestígio e voz, o movimento negro contemporâneo se reinventa. Kabegelê Munanga faz uma observação importante:

No que diz respeito aos movimentos negros contemporâneos, eles tentam construir uma identidade a partir das peculiaridades do seu grupo: seu passado histórico como herdeiros dos escravizados africanos, sua situação como membros de grupo estigmatizado, racializado e excluído das posições de comando na sociedade cuja construção contou com seu trabalho gratuito, como membros de grupo étnico-racial que teve sua humanidade negada e a cultura inferiorizada.

(MUNANGA, 2013, p. 100)

Muitos dos escritores marginais de periferia de hoje estão ligados a movimentos negros, portanto não é por acaso que eles buscam construir suas identidades a partir do passado histórico, exatamente como escreve Munanga. Carolina Maria de Jesus, em Diário de Bitita, volta ao passado e apresenta ao leitor a realidade de um país ainda com a abolição recentemente promulgada. Sua narrativa é construída em forma de denúncia, na voz de uma criança atenta aos problemas do mundo. Ela não foi uma outsider, como muitos pesquisadores a definem, ela foi uma mulher de seu tempo que dialogava com as questões do período, ao mesmo tempo em que se valia de uma representação positiva, orgulhosa de sua negritude. Nas palavras da própria autora em Quarto de despejo, "eu adoro a minha pele negra (...) Se é que existe reincarnações, eu quero voltar sempre preta."(DE JESUS, 2005, p. 62) 


\section{Múltiplas artes: a periferia e suas possibilidades expressivas}

Uma das propostas principais da presente pesquisa é explorar os múltiplos trabalhos confeccionados por Carolina Maria de Jesus ao longo de sua vida. A autora ficou conhecida por suas biografias, a mais famosa, Quarto de despejo, Ihe rendeu maior popularidade. Carolina compôs e cantou músicas, escreveu romance, poemas, tem um livro de provérbios e produziu roteiros teatrais. É importante destacar que, nas periferias brasileiras, os investimentos culturais são escassos e são ínfimos os contatos com instituições artísticas públicas e/ou privadas que fomentem projetos da população local. O capítulo trata justamente das estratégias elaboradas por essas populações tão ricas artisticamente, dando ênfase às questões do artista e suas múltiplas linguagens, tendo como recorte o período que vai dos anos 1960 até hoje.

Esta seção enfoca principalmente os movimentos de literatura marginal/periférica, surgidos no inicio dos anos 2000, considerando os temas arte, política e engajamento social, com destaque para projetos -- em parte, já tratados anteriormente -- de escritores como Sérgio Vaz, Ferréz e Allan da Rosa. Serão analisadas também algumas estratégias proporcionadas pela expansão da internet, facilitando a divulgação dos trabalhos e a elaboração de selos literários próprios, o que proporcionou maior visibilidade e circulação das obras apresentadas em eventos periféricos e assinadas por estreantes locais. Nesse contexto, estão inseridas as discussões sobre slam poético, a flexibilização entre as fronteiras da alta literatura e do popular, e até mesmo certa popularização da literatura, mesmo que o mercado editorial não participe dessa guinada. A questão da redescoberta, da releitura do trabalho de Carolina Maria de Jesus, no século XXI, diz muito sobre todo esse processo de empoderamento literário da periferia. A leitura das obras de Carolina feita atualmente é menos rotulada de "exótica" do que no ano de sua publicação, isso porque os leitores da última década, impulsionados pelo levante dos movimentos negros, coletivos feministas, associações comunitárias e outras formas organizacionais, além de tornarem-se maiores receptores e divulgadores das informações. A popularização da comunicação, através da internet, teve algum impacto minimizador da propagação difamatória machista e racista. Com a exposição imediata e em grande escala, textos preconceituosos são, logo, rechaçados e, assim, tendem a perder parte da força. 


\section{1}

\section{0 artista e suas múltiplas linguagens}

Carolina Maria de Jesus é reconhecida por escrever obras literárias de cunho autobiográfico, mas foi somente em 2013 que o pesquisador Sérgio Barcellos conseguiu viabilizar um valioso guia do acervo das obras da escritora. É possível que esse guia impulsione as pesquisas em outras perspectivas, já que as produções musicais, as peças teatrais, romances e os poemas da autora ainda não têm grande circulação nos meios acadêmicos. Vale lembrar que os trabalhos da autora são extensos e estão distribuídos em instituições arquivísticas de diferentes cidades como o Rio de Janeiro, São Paulo, Sacramento, MG e até mesmo Nova York.

A arte é uma forma de expressão complexa, é também um meio pelo qual as pessoas se reconhecem no mundo, sendo assim, a literatura é umas das muitas maneiras de interagir, de estar, de dialogar nos espaços. O objetivo desta seção é oferecer uma possibilidade de reflexão a respeito do efeito das experiências artísticas na vida de Carolina, como forma de interação com a sociedade, uma tática desenvolvida por essa observadora tão lúcida, que desejava propor soluções possíveis para problemas que seus contemporâneos enfrentavam. Uma das linguagens exploradas por Carolina foi a música, ouvinte assídua dos programas de rádio, a artista gostava também de cantar e dançar.

Foi então o sucesso de Quarto de despejo - o livro, que motivou Quarto de despejo, o disco. Carolina Maria de Jesus, gravou em 1961, um ano depois de lançar seu best-seller, músicas que ela mesma compôs. O raro LP possui 12 canções, a saber: "Rá ré ri ró rua"; "Vedete da favela"; "Pinguço"; "Acende o fogo"; "O pobre e o rico"; "Simplício"; "O malandro"; "Moamba"; "As granfinas"; "Macumba"; "Quem assim me ver cantando"; "A Maria veio". A obra pertence ao Acervo José Ramos Tinhorão e está sob a guarda do Instituto Moreira Salles. Provavelmente o título do LP recebe o nome do livro para impulsionar as vendas, mas seu conteúdo é amplo e variado dialogando com as questões de Quarto de despejo. A recente conquista do Nobel de literatura pelo cantor e compositor Bob Dylan trouxe novamente a questão: música é ou não é literatura? Valendo-se do conceito de intermidialidade do professor de literatura comparada, Claus-Clüver, é preciso se debruçar sobre alguns conceitos pertinentes ao tema. Seu conceito abarca a compreensão de arte como mídia e, portanto, ao relacionar poesia à música, as duas como forma de arte autônoma, surgirão duas mídias distintas, algo denominado como uma relação intermidiática. Já 
no tocante ao texto escrito, como elemento da própria música (letra) ou da literatura (poema escrito), será entendido como algo único, pertencente à mesma mídia, havendo assim uma relação intramidiática.

A partir dessa perspectiva intramidiáticade que literatura e música se fundem, Carolina em uma das músicas de seu LP aborda um tema bastante explorado em Quarto de despejo -- a questão do casamento. A autora não só crítica o casamento do ponto de vista feminino, como também propõe o fim do mesmo, no texto que foi musicado. O papel destacado, na letra, é o da mulher que põe o marido na rua.

Ra, Ré, Ri, Ró, Rua

Você vai embora que esta casa não é tua

Ra, ré, ri, ró, rua

Você vai embora que esta casa não é tua

Você chega de madrugada

Fazendo arruaça e xaveco

Além de não comprar nada

Ainda quebra o meus cacareco

Rá rárárá

Ra, ré, ri, ró, rua

Você vai embora que esta casa não é tua

Arrependi de me casar

Que a nossa vida assim não vai

Qualquer dia eu vou te abandonar

E vou voltar para casa de papai

Rá rárárá

Ra, ré, ri, ró, rua

Você vai embora que esta casa não é tua

Andas dizendo que eu sou ingrata

Casaste, mas já arrependeu

Mas é você quem me maltrata

E a infeliz nessa casa sou eu

Rá rárárá

Ra, ré, ri, ró, rua

Você vai embora que essa casa não é tua

(Radio Batuta, IMS)

Fiel as suas convicções, seja representando suas ideias através das narrativas literárias ou na forma de canção, Carolina se mostra uma artista que se vale de múltiplas linguagens expressivas. Ela registra, em seu diário, o desejo de Seu Manoel de se casar com ela mas, em seguida, avalia que "um homem não há de gostar de uma mulher que não pode passar sem ler. $E$ que levanta para escrever. $E$ que deita com lápis e papel debaixo do travesseiro. Por isso é que eu prefiro viver só 
para o meu ideal. "Em sua canção, a escritora reafirma sua visão do casamento, retratando o contrato matrimonial como algo não vantajoso para a mulher, como um tormento, a mulher como vítima de violência doméstica e maus tratos.

Transpondo a questão intramidiática, é possível perceber na melodia da canção e na construção rítmica de sua composição o tom irônico que a cantora atribui ao evento, uma vez que o próprio título é jocoso: Rá ré ri ró rua. No $8^{\circ}$ verso "Rá ré ri ró rua", que é o título, mas também funciona como refrão, dá lugar a "rá rá rá rá", levando a crer que equivale a um "quem ri por último ri melhor", afinal é a voz feminina do poema exigindo a partida do então marido. A segunda música é intitulada "Vedete da favela", nela, Carolina Maria de Jesus parece fala de si mesma como vedete, que é o mesmo que estrela, atriz principal dos espetáculos, diva. "Ela" estava vaidosa porque havia obtido prestígio, por isso se proclamou a "vedete da favela".

\section{Vedete da Favela}

Salve ela

Salve ela

Salve ela

A vedete da favela

Conhece a Maria Rosa?

Ela pense que é a tal

Ficou muito vaidosa

Saiu seu retrato no jornal

Salve ela

Salve ela

Salve ela

A vedete da favela

Maria conta vantagem que comprou muitos vestidos

Preparou sua bagagem

Vai lá pros Estados Unidos

Salve ela

Salve ela

Salve ela

A vedete da favela

(Radio Batuta, IMS)

Vale mencionar que, mesmo não fugindo de sua realidade periférica a escritora tem uma visão positiva sobre si, diferente de denominações encontradas nos periódicos da época. A melodia dessa canção é alegre, festiva e mesmo que breve, a música contém um tom de felicidade. Essa canção se faz presente em pelo menos duas apresentações teatrais recentes sobre a vida artística de Carolina. A peça "Salve 
ela: Carolina Maria de Jesus em cena", apresentada pela Cia. Alternativa de Teatro, do Rio de Janeiro, teve uma curta temporada no ano de 2017, podendo ser vista inicialmente no teatro Ziembinski, localizado no bairro da Tijuca. A peça prestigiava a produção de Carolina a partir de uma de suas peças teatrais intitulada "Obrigado Senhor Vigário". A Cia de teatro se vale de uma metalinguagem, já que opta pela difícil tarefa de abordar a peça teatral de Carolina na própria peça teatral sobre Carolina. Eles não perdem o eixo condutor da história, e num misto de drama e comédia o trio de atores: Fernanda Dias, Getúlio Nascimento e Ribamar Ribeiro se diversificam entre os cenários e a troca de indumentárias para comporem a encenação.

"Obrigado Senhor Vigário" é um texto composto por oito personagens, pode ser caracterizado como romântico e dramático, já que a grande questão da história é a vida de Clara, que teve na morte precoce de seu pai o impulso de todos os seus infortúnios. Como Clara perde seus pais ainda na infância, sua tutoria e administração de seus bens fica ao encargo de seu tio e sua respectiva esposa, a menina leva uma vida de escrava, mas ao ser obrigada a se casar com alguém por quem não se interessava, justamente no dia da cerimônia recebe a revelação de sua origem por meio do padre que celebraria o casamento. De posse de seus bens, Clara não se casa e segue sua vida. O breve resumo da narrativa é convencional, uma fórmula presente há séculos na literatura. A figura de uma menina triste que sofre por ter uma vida difícil calcada no modelo cristão da máxima "Os humilhados serão exaltados", presente na passagem bíblica "Quem a si mesmo se exaltar será humilhado; e quem a si mesmo se humilhar será exaltado". Carolina foi influenciada pelas radionovelas, um tipo de drama radiofônico no formato de uma narrativa folhetinesca sonora, oriunda da dramatização do gênero literário novela, produzida e divulgada em rádio, que teve muita repercussão no Brasil dos anos 1950.

O que sobressai no texto de Carolina é a quebra de expectativa que a autora confere a seu leitor, uma vez que a sua protagonista consegue se desvencilhar do casamento arranjado e seguir solitariamente em sua vida. Mais uma vez Carolina representa a instituição do casamento como algo negativo ou desimportante na trajetória feminina. E assim, através da escrita ela vai se colocando no mundo. Escrever era o grande objetivo da autora, e Carolina fez dessa meta algo próprio, substancial em sua vida. Relendo a obra de Conceição Evaristo é notório a conexão que a autora estabelece com Carolina. Evaristo afirma ser parte constituinte de um conjunto de escritoras negras, oriundas de periferias em que Carolina é a mulher que criou uma tradição literária. E ela cita:

Quando mulheres do povo como Carolina, como minha mãe, como eu também, nos dispomos a escrever, eu acho que a gente está rompendo com o lugar que normalmente nos é reservado. A mulher 
negra, ela pode cantar, ela pode dançar, ela pode cozinhar, ela pode se prostituir, mas escrever, não, escrever é alguma coisa... é um exercício que a elite julga que só ela tem esse direito. Escrever e ser reconhecido como um escritor ou como escritora, aí é um privilégio da elite.

(Evaristo, 2010).

No imaginário coletivo do brasileiro a escrita se constitui como um lugar específico da elite, não à toa que há resistência social como escritoras como Carolina Maria de Jesus e Conceição Evaristo ocupam esses lugares. Elas rasuram o que está posto e se estabelecem a partir de suas escrevivências. O termo é um referencial importante para essa concepção de literatura de escritoras que vivenciam um processo criativo marcado por dramas sociais. O conceito surge em 1995, e é uma fusão dos vocábulos "escrever" e "viver". Conceição, ao tratar do tema mulheres e literatura, afirma que a escrevivência das mulheres negras "não é para ninar os filhos da Casa Grande, e sim para incomodá-los em seus sonos injustos". Escrevivência tem a ver, portanto, com autobiografia, com a experiência visceral de ser e estar no mundo e junto a isso fazer da literatura a vida e da vida literatura. É não sedimentar vida e arte, é transpor as questões de raça e gênero por meio de recursos artísticos. Assim, Carolina se vale de múltiplas linguagens manifestadas em diversificados gêneros textuais de modo a expandir e expressar o seu pensamento e dar sentido a suas subjetividades.

\section{2}

\section{Arte e política: literatura, negritude e o engajamento necessário}

O filósofo Aristóteles considera que a prática política está na essência do humano, devendo, assim, ser desenvolvida e realizada em todas as instâncias da sua existência: educacional, social e cultural. Apesar de a atividade política ser tida como condição natural, a mesma precisa ser aprimorada. Uma das vantagens da emergência do movimento literário dos anos 2000 foi justamente a politização dos envolvidos e as articulações sócio comunitárias engendradas por eles. Todos os autores citados neste trabalho possuem uma prática social focada em suas comunidades. Alan da Rosa, Ferréz e Sérgio Vaz, em espaços e através de estratégias diferentes, são atuantes e poderiam se encaixar no conceito de intelectual 
orgânico de Gramsci, uma vez que são intelectuais que se voltam para as suas classes de origem com o objetivo de emancipar sua comunidade.

Sérgio Vaz é um importante expoente da favela, o que o torna um considerável símbolo cultural do movimento de mobilização artística da periferia. É importante refletir sobre a atuação de escritores como Sérgio Vaz, que, para além da produção escrita, desenvolve trabalhos comunitários para sensibilizar e envolver a comunidade. A atuação do escritor possibilita reflexão e noção de pertencimento. Ortiz (2011), ao abordar a relevância e o papel do intelectual afirma que: "A construção da identidade nacional necessita, portanto desses mediadores que são os intelectuais. São eles que descolam as manifestações culturais de sua esfera particular e as articulam a uma totalidade que as transcende. Em seu texto intitulado "Manifesto da antropofagia periférica", Sérgio Vaz ressalta a importância desse artista engajado:

É preciso sugar da arte um novo tipo de artista: o artista-cidadão. Aquele que na sua arte não revoluciona o mundo, mas também não compactua com a mediocridade que imbeciliza um povo desprovido de oportunidades. Um artista a serviço da comunidade, do país. Que, armado de verdade, por si só exercita a revolução. Contra a arte domingueira que defeca em nossa sala e nos hipnotiza no colo da poltrona.

(VAZ, Sérgio, 2011, p.38)

Existe, na visão de Vaz, uma função para o escritor da periferia que ultrapassa o papel atribuído ao artista. Ele acredita que um autor deve estar a serviço da comunidade, informando e formando posicionamentos. A questão racial é um componente importante nessa questão, isto porque, a mídia, principalmente a televisiva, retrata o Brasil como um país que tenha superado o racismo. As falas de Sérgio Vaz contribuem para uma série de questionamentos referentes ao tema:

Às vezes as pessoas acham que a gente mora numa grande senzala. Parece que somos incapazes de falar sobre literatura, sobre política, sobre economia. Nós parecemos uma ilha de Lost! Eles [da elite brasileira] estão surpresos: Quanto pobre! Quanto preto! Não somos brasileiros, somos palestinos. Temos de criar aquela OLP, Organização para a Libertação da Periferia.

(Entrevista concedida ao site viomundo em 16 de janeiro de 2014)

Nessa entrevista, o autor questiona a maneira como são interpretados por parcelas da elite brasileira os que vivem na periferia, referida, por ele, como uma "grande senzala". Existe falta de confiança na capacidade de os moradores de periferia se organizarem e produzirem, por iniciativa própria, eventos culturais e artísticos que valorizem a cultura local. A produção da literatura é entendida, nesse 
contexto, como algo incompatível com a realidade vivenciada pela população de baixa renda, que tem de morar nos subúrbios e favelas. Olhados pela burguesia, parecem incapazes de articular-se como um conjunto de produtores de arte e literatura conscientes de seu papel transformador. No entanto, os movimentos, associações e saraus desmentem as expectativas burguesas. Os artistas da periferia vêm dominando mecanismos transmissores eficientes para a difusão de suas reivindicações e sua arte. De acordo com o crítico Antônio Cândido, a literatura é um sistema de obras ligadas por denominadores comuns. O crítico também entende a literatura como um sistema simbólico, dotado de força identitária, nacional:

[...] Além das características internas (língua, temas, imagens), certos elementos de natureza social e psíquica, embora literariamente organizados, que se manifestam historicamente e fazem da literatura aspecto orgânico da civilização. Entre eles se distinguem: a existência de um conjunto de produtores literários, mais ou menos conscientes do seu papel; um conjunto de receptores, fornecendo os diferentes tipos de público, sem os quais a obra não vive; um mecanismo transmissor (de modo geral, uma linguagem, traduzida em estilos) que liga uns a outros. O conjunto dos três elementos dá lugar a um tipo de comunicação inter-humana, a literatura, que aparece, sob este ângulo como sistema simbólico.

(CANDIDO, 1971, p. 70)

Não só é possível identificar um conjunto de produtores literários conscientes de seu papel, como também destaca-se um público diversificado estabelecido além das fronteiras periferia/centro. Por conta dessa constatação, fica evidente que a produção da periferia, escrita pela periferia, inclui-se perfeitamente no espaço da arte literária. A função social do escritor é algo muito difundido por Sérgio Vaz, seja em sua literatura, seja em seus eventos culturais. A literatura adquire nesse contexto o sentido estabelecido por Johson apud Compagnon "O único fim da literatura é tornar os leitores capazes de melhor gozar a vida, ou de melhor suportá-la.". Quando a literatura serve este ou aquele grupo, atendendo a este ou àqueles interesses, ela perde seu viés democrático, uma vez que está a serviço de interesses específicos.

Antoine Compagnon (2009), ao dissertar sobre as faculdades da literatura reitera que "ela tem o poder de contestar a submissão ao poder". Essa é a principal ferramenta do autor: contestar a submissão. A desigualdade social causada pelo processo de escravização dos negros no Brasil, a marginalização cultural e étnica enfrentada principalmente pelos moradores das periferias brasileiras, são algumas das grandes pautas estabelecidas pela Cooperifa e pelo trabalho literário individual de Sérgio Vaz. Além dos saraus itinerantes e do evento que ocorre toda quarta-feira no 
bar Zé Batidão, o autor atua como palestrante em escolas públicas de diversas áreas de São Paulo.

Há grande interesse em que os intelectuais diversifiquem os objetos de suas pesquisas, considerem os elementos culturais representativos do Brasil. As atividades inventivas de sua população e a -- muito comentada e insuficientemente compreendida -- diversidade cultural, incluindo a diversidade linguística foram ressaltadas por Darcy Ribeiro:

A sociedade e a cultura brasileiras são conformadas como variantes da
versão lusitana da tradição civilizatória europeia ocidental,
diferenciadas por coloridos herdados dos índios americanos e dos
negros africanos [...] A confluência de tantas e tão variadas matrizes
formadoras poderia ter resultado numa sociedade multiétnica,
dilacerada pela oposição de componentes diferenciados e imiscíveis.
Ocorreu justamente o contrário, uma vez que, apesar de sobreviverem
na fisionomia somática e no espírito dos brasileiros os signos de sua
múltipla ancestralidade, não se diferenciaram em antagônicas minorias
raciais, culturais ou regionais, vinculadas a lealdades étnicas próprias e
disputantes de autonomia frente à nação.

(RIBEIRO, 2009, p. 120)

Em tese, a miscigenação brasileira é um componente de orgulho, símbolo da identidade nacional. Porém, ORTIZ, (2011) atesta que "as relações raciais no Brasil são obscurecidas pela ideologia da democracia racial". Para além da questão teórica, essa noção traz algumas implicações, uma delas é a de que os "índios americanos" e os "negros africanos" que figuram o "colorido da tradição civilizatória europeia ocidental" tiveram suas culturas subjugadas, sua população massacrada e dizimada. O resultado são as consequências históricas da marginalização do negro e a dispersão ou até mesmo a extinção completa de inúmeras etnias indígenas. A democracia é uma reivindicação constante dessa parcela da sociedade brasileira. As afirmações contemporâneas correspondem a transformações das práticas investigativas do início do século $\mathrm{XX}$, quando o negro começava a ser integrado às preocupações nacionais por conta dos movimentos abolicionistas; foi, nesse contexto, que a obra de Gilberto Freyre transformou a negatividade do mestiço em positividade, conferindo outra feição à nacionalidade.

A preocupação artística do movimento modernista era a propagação da ideia de um país vasto culturalmente, que considera suas matizes étnicas miscigenadas e tem como protagonista o brasileiro comum e seus hábitos. O compromisso modernista era trazer novas pautas para a arena artística e social, durante séculos caracterizada pela predominância dos padrões europeus. Ortiz (2011) reconhece que o modernismo trouxe uma consciência histórica até então esparsa na sociedade. Trata-se da 
consciência dos diferentes níveis de contágio entre as culturas europeias (já miscigenadas por séculos de contato com culturas africanas e asiáticas)e as múltiplas línguas, mitologias e costumes indígenas, com a superposição dos legados culturais das também diversas etnias africanas. O projeto de nacionalização modernizadora, instaurado pelo movimento de 1922, buscou integrar epistemológica e esteticamente essa heterogeneidade - o que vem acontecendo em velocidades variáveis (com progressos e recuos) e com ênfases distintas ao longo de quase um século.

O poema de Oswald de Andrade intitulado "brasil" reflete "a ideologia do Brasil cadinho" e "relata a epopeia das três raças que se fundem nos laboratórios das selvas tropicais." ORTIZ (2011, p.24). O poema expressa ainda uma concepção nacionalista e reflete a ideia de pertencimento identitário exposto por Darcy Ribeiro.

$$
\text { brasil }
$$

O Zé Pereira chegou de caravela

E perguntou pro guarani de mata virgem

-Sois cristão? -Não, sou bravo, sou forte, sou filho da morte

TetetêtetêQuizáQuecê!

Lá de longe a onça resmungava

Uu! Ua! Uu!

O negro zonzo saído da fornalha

Tomou a palavra e respondeu

A exposição, acima, mostra como a literatura é uma importante ferramenta social. Dando sequência à série de eventos -- mais ou menos eficientes, mais ou menos empenhados na efetiva integração --, constituintes do que se pode considerar a brasilidade, sempre conduzida pelas camadas burguesas, observa-se, nas últimas décadas, o protagonismo de pontas de lança das populações cujos traços culturais foram recalcados. A partir do momento em que grupos excluídos socialmente, sem acesso à cultura formal, pouca instrução escolar, começam a se apropriar de instrumentos próprios da clave elitista, como literatura e artes visuais, esses grupos vão conseguindo romper com um ciclo histórico previsível e reescrevem suas trajetórias. Sérgio Vaz, ao proclamar a relevância do artista cidadão para as condições de vida da periferia, reconhece o potencial social da arte. Consciente dessa importância, Sérgio Vaz elabora diversos eventos moldados nos projetos culturais de grande prestígio brasileiro. Um exemplo de destaque nesse sentido, é a criação do blog APL (Academia Periférica de Letras).

A Academia Periférica das Letras é um blog que concentra notícias e informações sobre festas, lançamento de livros, pesquisas e encontros na área acadêmica sobre a produção literária em contexto periférico. Existem outros eventos como mostras culturais da periferia e feiras literárias específicas para comunidades 
pobres e periféricas. Fato é que, nos últimos anos, a periferia tem-se organizado para difundir e valorizar suas práticas de maneira independente. Os mais pobres têm-se ocupado da literatura e, por dela, expressam o racismo, o preconceito e a violência enfrentada por eles. Segundo Compagnon (2009), a literatura pode ser entendida, no sentido mais amplo, como "tudo o que é impresso (ou mesmo manuscrito), são todos os livros que a biblioteca contém (incluindo-se aí o que se chama literatura oral, doravante consignada)."

Em termos menos genéricos, Compagnon (2009) afirma que a literatura varia consideravelmente segundo as épocas. Ou seja, de acordo com os critérios estabelecidos em determinado momento, um texto pode ser literário ou não. A população mais pobre, marginalizada, que tem acesso precário à educação, portanto, maior dificuldade com o código da escrita, tem uma cultura predominantemente oralizada, refletindo essa característica na produção literária. Oswald de Andrade, no "Manifesto da Poesia Pau-Brasil" (1924) enaltece a linguagem popular: "A língua sem arcaísmos, sem erudição. Natural e neológica. A contribuição milionária de todos os erros. Como falamos. Como somos." Como divulgado pelo escritor moderno, é preciso considerar a riqueza que a diversidade oferece, assim como as amplitudes da esfera literária. Para além dos recursos estéticos, de aguçar a imaginação, comover e sensibilizar, a literatura pode ter uma função social, uma vez que exprime sentimentos próprios dos seres humanos. Um texto pode questionar a ordem vigente dos fatos, denunciar injustiças, tecer elogios sobre atitudes, desqualificar medidas etc. Ao falar sobre a arte, Alfredo Bosi afirma que:

Não é o Estado, nem a Universidade, nem a Igreja, nem a Imprensa, nem qualquer das instituições conhecidas que deverá encarregar-se do destino das letras e das artes. O clima natural destas é o da liberdade de pesquisa formal e de descoberta de temas e perspectivas. A arte tem seus modos próprios de realizar os fins mais altos da socialização humana, como a autoconsciência, a comunhão com o outro, a comunhão com a natureza, a busca da transcendência no coração da imanência.

(BOSI, 2010, p. 67)

Ou seja, nenhuma instituição deve interferir negativamente nos desdobramentos artísticos de seu povo. As discussões acadêmicas ainda estão afastadas das questões que permeiam as populações marginalizadas socialmente. Os espaços escolares não contemplam a pulsão artística que permeia as mais diversas favelas brasileiras. É próprio do tempo oferecer novos temas e perspectivas, cabe portanto às instituições acompanharem o fluxo cultural dos eventos, não elegendo parâmetros que reproduzam a desigualdade social, uma vez que a arte não deveria se 
submeter a tais critérios. Nesse sentido, na virada do milênio a literatura brasileira trouxe novos contornos para o campo literário. Mas, como todo símbolo cultural, a nova perspectiva literária ou a nova possibilidade de se fazer literatura se transformou em disputa. Diversos meios culturais de prestígio não reconhecem essa escrita das populações periféricas (oralizada, inflada de africanismos rituais, expressões estrangeiras do circuito hip-hop e coloquialismos locais) como sendo artística, tornando assim seus textos, objeto de investigações sociológicas e não literários.

Ao mesmo tempo, em que, a partir das periferias urbanas, a literatura é "descoberta" como um importante instrumento de poder para as camadas mais populares, ela forma vai perdendo espaço na sociedade globalizada, como veículo de acesso amplo e constante. Compagnon (2009), ao tratar dessa questão, pondera que:

O espaço da literatura tornou-se mais escasso em nossa sociedade há uma geração: na escola, onde os textos didáticos a corroem, ou já a devoraram; na imprensa que atravessa também ela uma crise, funesta talvez, e onde as páginas literárias se estiolam; nos lazeres, onde aceleração digital fragmenta o tempo disponível para os livros. "

(COMPAGNON, Antoine. 2009, p 34)

Essa confluência contraditória do circuito literário hegemônico e do periférico ascendente talvez possa mostra-se, no futuro próximo um sinal positivo de que a fragmentação de redes culturais é que abre espaço para a fixação de novas agencias, ao lado do retorno de vozes silenciadas. Na contemporaneidade dominada pelas tecnologias de alcance amplo, que privilegiam a circulação das imagens, a potência sonoro-rítmica das populações envolvidas por tradições africanas globalizadas compete com outras tendências e impõe-se a várias camadas sociais. No movimento saudável de resgate de agentes do passado, a prática dos saraus, a resistência antirracista e a sobrevivência do rap trouxeram de volta, para conhecimento das novas gerações, a literatura de Carolina Maria de Jesus.

A permanência ou não da literatura não é em si uma grande questão quando o tema é relacionado a mudanças, a literatura resiste ao tempo, se adapta, se transforma, a discussão sobre o suporte, a ferramenta de disponibilização da mesma é um assunto pertinente, no entanto é relevante refletir sobre como a literatura é captada por essas camadas populares em tempos de transformação. Caminhando juntamente com as propostas literárias dentro das perspectivas atuais da literatura marginal/periférica está o rap. É inegável a intercessão existente entre as duas mídias. O rapper Criolo tem um poema intitulado "duas de cinco". 
Considerando novamente a perspectiva Intramidiática em que texto musical e texto literário se fundem é possível estabelecer mais consistência à discussão sobre a assimilação literária pelas periferias:

Duas de Cinco

[Refrão]

Compro uma pistola do vapor

Visto o jaco Califórnia azul

Faço uma mandinga pro terror

E vou...

É o cão, é o cânhamo, é o desamor

É o canhão na boca de quem tanto se humilhou

Inveja é uma desgraça, alastra ódio e rancor

E cocaína é uma igreja gringa de Le Chereau

Pra cada rap escrito

Uma alma que se salva

O rosto do carvoeiro

É o Brasil que mostra a cara

Muito blá se fala

E a língua é uma piranha

Aqui é só trabalho, sorte é pras crianças

Que vê o professor em desespero na miséria

Que no meio do caminho da educação havia uma pedra

E havia um pedra no meio do caminho

Ele não é preto véi

Mas no bolso leva um cachimbo

É o Sleazestack

Zóio branco, repare o brilho

Chewbacca na penha

Maizena com pó de vidro

Comerciais de TV

Glamour pra alcoolismo

E é o kinect do XBOX

Por duas buchas de cinco

\section{$(\ldots)$}

Kleber Cavalcante Gomes, conhecido como Criolo, é natural da cidade de São Paulo. Cresceu no bairro populoso e pobre denominado Grajaú, localizado na Zona Sul paulista. É um cantor diferenciado na cena musical do estilo, já que se consagrou como músico de relevância nacional, estabelecendo parcerias com cantores como Chico Buarque e Caetano Veloso. Sua música faz referência ao famoso poema de Carlos Drummond de Andrade "No meio do caminho". A letra-poema é complexa, repleta de metáforas e ilustrações, desenvolvida em dois cenários, o primeiro (refrão) é composto por uma voz diferenciada, mas que textualmente pode ser percebida por meio da repetição (refrão). É retratado uma pessoa que vai comprar uma arma para cometer algum tipo crime "Faço uma mandinga pro terror/ e vou". A segunda parte é 
dominada por um sujeito que enxerga os eventos de modo crítico, a vida em si permeada de angústia, dificuldades, tentativas. A poesia de Criolo é bem estruturada, tem musicalidade, informação, intertextualidade, filosofia e arte. Criolo não só dialoga com escritores como Ferréz e Sérgio Vaz, ele está inserido em diversos projetos dos dois escritores. Na letra de "Esquiva da Esgrima" Criolo cita o próprio Ferréz:

\author{
"Do Grajaú ao Curuzu, pra imigração meu povo é mula \\ Inspiração é Black Alien, é Ferrez não é Tia Augusta \\ Verso mínimo, lírico de um universo onírico \\ Cada maloqueiro tem um saber empírico \\ Rap é forte, pode crêr, Ui messier \\ Perrenoud, Piaget, Sabotá, Enchanté"
}

Criolo em seus versos valoriza o saber da rua, encarnada na figura do maloqueiro, inspirado em personalidades importantes dentro das periferias, como o rapper Black Alien e o escritor Ferréz. Os movimentos literários emergentes nos anos 2000 trouxeram em suas complexidades outras formas de expressividade, em que se rompem cada vez mais os limites linguísticos, artísticos, formais que compunham a literatura desde então. E esses grupos investem em recursos distributivos que não dialogam com as expectativas do universo literário tradicional. Os moradores de favela não vão até a livraria para ter o objeto livro. Eles têm acesso à poesia por meio das redes sociais, e o próprio Sérgio Vaz disponibiliza seus poemas no Facebook, poemas esses que estão em seus livros. Ele não deixa de vendê-los, mas a circulação de seus textos flui com muita força no Facebook, por exemplo.

\title{
4.3
}

\section{Literatura expandida: da literatura marginal ao mainstream}

O privilégio de eleger obras literárias está ligado à questão de poder. As escolhas não são arbitrárias, toda a história da literatura brasileira constata esses interesses mencionados por Roberto Reis. Os critérios para avaliar uma obra literária estão ligados aos seus méritos estéticos, ou seja, sua "literariedade". A problemática da questão está situada na noção de literatura, que a princípio é ideológica e está engendrada na burguesia. Portanto seus valores estéticos e culturais que vão atestar essa "literariedade" estão sob a ótica desse grupo.

A utilização do termo 'marginal' para a caracterização de um tipo de produção textual demanda uma análise cuidadosa quanto ao objeto de estudo. Alfredo Bosi ao escrever o prefácio do livro de João Antônio, relata que "(..) o termo 'marginal' é fonte 
de equívocos; sei que na sociedade capitalista avançada não há nenhuma obra que, publicada, se possa dizer inteiramente marginal". O crítico, ao fazer uso da palavra 'inteiramente', oferece a chave para a questão. Uma vez que as obras referidas são assimiladas por editoras e passam a ser objeto de estudo nas academias, não é mais possível classificá-las como por inteiro 'marginais'.

Uma obra que é objeto de estudos acadêmicos, premiada em meios literários, lançada por editoras significativas, como ocorrido com esses escritores, não pode ser considerada como 'inteiramente marginal'. Bosi estava se referindo a obra de João Antônio, porém sua aplicabilidade é bastante eficaz no conteúdo exposto, já que ambas são caracterizadas 'marginais' pelos mais variados sentidos atribuídos. O 'marginal' está sempre se opondo a alguma coisa, e ao que se opõe em um determinado período, não precisa necessariamente opor-se em outro. Ferréz participou da Bienal Internacional do Livro de São Paulo em 2018, compõe a enciclopédia Itaú cultural, apesar de ter um selo editorial relevante, sua principal obra é publicada pela importante editora Objetiva, fato que demonstra certo prestígio de seus trabalhos, além disso tem pelo menos nove livros publicados. Sérgio Vaz além de estar inserido na Enciclopédia Itaú Cultural de Literatura Brasileira, participa de inúmeros eventos promovidos pelo Itaú Cultural, tem quatro livros publicados e em 2018 foi lançado o documentário "Sarau da Cooperifa: povo lindo, povo inteligente". Alan da Rosa apresenta um perfil mais acadêmico, além de ter seu próprio selo editorial, possui seis livros publicados, seus livros são elogiados no Brasil e no exterior, constantemente é convidado a participar de eventos literários, no Brasil e no mundo. De fato, alguns escritores tidos como 'marginal' desfrutam de notoriedade e prestígio em certos meios literários.

Porém, ao utilizar a noção de cânone literário, esse protagonismo se torna mais frágil. Roberto Reis (1992) ao retomar a etimologia da palavra cânone remete-se ao grego "kanon" uma espécie de vara de medir, mas que nas línguas românicas tinha o sentido de "norma" ou "lei". O autor trabalha com o termo atribuindo suas implicações seletivas e excludentes vinculadas às questões de poder. $\mathrm{Na}$ literatura esse termo é utilizado como uma contínua lista de modelos de obras tidas como clássicas, de significativo valor. Os clássicos são tidos como patrimônios, representantes de uma cultura. Nessa perspectiva, é possível tecer algumas considerações sobre a noção de poder que está embutida na noção de cânone, já que, ao selecionar uma lista das ditas obras-primas de uma dada cultura, serão levados em consideração critérios. Os parâmetros que estabelecem os modelos são também os que excluem. 
Cabe ressaltar, no entanto, que a popularização do uso da internet e o alcance das redes sociais e as plataformas de compartilhamento, principalmente, trouxeram questões que até então não esbarravam na forma de se fazer/experimentar literatura até então . Em 2004, Marcelino Freire organiza uma coletânea denominada "Os cem menores contos brasileiros do século", lançado pela editora Ateliê. Na época em questão, a fórmula "os cem melhores" estava em voga, e o prefácio do livro, obedecendo à regra dos 50 caracteres, foi escrito por Italo Moriconi, autor de "Os cem melhores contos brasileiros do século". O livro é um marco porque assinala uma proposta diferente do que circulava até então naquele momento. Vale lembrar que a rede social Twitter (famosa pela restrição de caracteres) só foi lançado em 2006, mas a questão dos caracteres já estava presente no cotidiano, uma vez que o envio de mensagens nos celulares e os comentários em sites eram restritos a partir dessa perspectiva enxuta, básica do uso dos recursos da linguagem.

Entre os anos de 2017 e 2018 as editoras vivem uma grande crise e impulsionadas ainda por um efeito cascata atingindo livrarias como Saraiva, Cultura e Fnac, perdem dinheiro os empresários e ainda mais os escritores, que muitas vezes não conseguem sobreviver apenas com a publicação de seus livros. Vender livros no Brasil sempre foi difícil, no entanto os últimos anos exigem uma mudança em relação às práticas editoriais. Mas nem tudo nesse cenário é de se lamentar. Isso porque há pelo menos cinco anos a literatura tem ganhado cada vez mais força na internet. A notória presença dos grupos marginais na internet, seja por distribuição de conteúdo exclusivamente políticos, seja para difusão de linguagens artísticas, tal medida repercutiu nas relações sociais do brasileiro. Impulsionados pelo discurso da valorização dos pobres, do empoderamento feminino, da validade estética do negro e até mesmo do questionamento do status quo. Em matéria publicada no site $\mathrm{Nexo}^{10}$ é possível perceber a concretização da poesia nas ruas, em forma de slam.

Em novembro de 2016, a Flupp (Festa Literária das Periferias), no Rio de Janeiro, sediou o primeiro campeonato de poesia falada internacional da América Latina, o Rio Poetry Slam. A competição recebeu 'slammers' de 16 países diferentes e teve como campeã a poeta paulistana Mel Duarte, autora do livro "Negra Nua Crua". Os slams são campeonatos de poesia. Normalmente, os participantes têm até três minutos para apresentarem sua performance - uma poesia de autoria própria, sem adereços ou acompanhamento musical. O texto pode ser escrito previamente, mas também pode haver improvisação. Não há regras sobre o formato da poesia.

\footnotetext{
10 Disponível em: < https://www.nexojornal.com.br/expresso/2016/12/20/O-que-s\%C3\%A3o-slams-ecomo-eles-est\%C3\%A3o-popularizando-a-poesia>. Acesso em 20 fev. 2019.
} 
A matéria traz ainda a informação de que o slam foi criado nos anos 1980 em Chicago, nos Estados Unidos, ao mesmo tempo em que a cultura hip hop tomava forma, por lá era denominado "Slam Poetry". Os slams estão associados à cultura dos saraus organizados na periferia. A pesquisadora Jéssica Balbino explica a dinâmica dos slams:

\begin{abstract}
"Para competir no slam, a pessoa não precisa ter livro publicado, ser rapper, ser artista, nada. Vale para donas de casa, taxistas, vendedores, etc. No sarau também, claro. Existe algo de: todos podemos fazer poesia. Todos podemos usar a palavra para nos manifestarmos. Não há necessidade de um livro publicado para validar o ofício de poeta e/ou slammer"
\end{abstract}

Num mundo em que de modo muito veloz os paradigmas são deixados para trás sem que antes dê tempo de discutir de modo mais aprofundado sobre as a questões ali expostas, a literatura de hoje se mostra ainda mais multifacetada, flertando com o cênico, liberta do suporte concreto - o livro, musicada, ritmada, reinventada, dinâmica, fluida, recitada por todos e acessível.

\title{
4.4
}

\section{Carolina Maria de Jesus: a redescoberta do século XXI}

Doodle é um termo em inglês que designa um desenho livre, feito em um momento de distração ou ocupação. Poderia ser traduzido para o português como um rabisco, mas não de forma pejorativa, e, sim, no sentido de um desenho feito de modo simples, sem necessariamente representar algo reconhecível. Sendo assim, um Google Doodle "é uma alteração especial e temporária do logotipo nas páginas iniciais do Google, destinada a comemorar feriados, eventos, conquistas e figuras históricas notáveis". Em 14 de março de 2019, o Google homenageia Carolina Maria de Jesus, que completaria 105 anos.

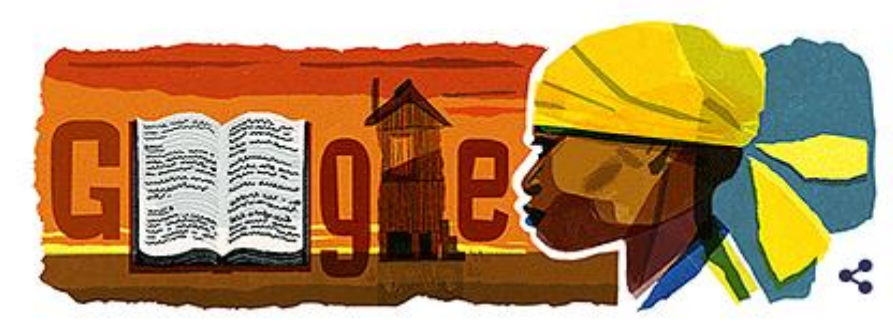

14 de março de 2019 - Doodle em homenagem a Carolina te

$$
\text { Pesquisa Google Estou com sorte }
$$

Figura 5 - Doodle comemorativo de Carolina Maria de Jesus 
É um gesto muito importante se for avaliado o alcance dessa homenagem. $O$ Google, além de ser uma empresa multinacional de serviços online, hospeda os principais produtos e serviços da internet, é um gesto de suma importância, uma vez que traz visibilidade para a produção literária da escritora.

Nos últimos dez anos o interesse em Carolina vem aumentando, em decorrência disso, mais pesquisadores se propõem a pesquisar a vida da autora, uma vez que muitas lacunas em relação a Carolina e seus trabalhos precisam ser investigados. Em 2017, mais uma biografia foi lançada no intuito de entender a vida de Carolina, lançada pela editora Malê, focada em autores negros, e escrito por Tom Farias, o livro, intitulado "Carolina - Uma Biografia", traz informações relevantes a respeito da trajetória de Carolina. Tom Farias afirma que:

A parte mais reveladora do estudo é sobre a fase em que ela morou no Rio de Janeiro - um dos lugares foi a cidade de Nilópolis. Carolina esteve por quase dois anos no Rio, entre o final de 1940 e 1942. Veio tentar a carreira como "poetisa preta", como se qualificava. A outra revelação é que ela ensaiou ser jornalista em um jornal paulista e também se dispunha a dar aulas na favela do Canindé.

Conforme mais pesquisadores se comprometem com o trabalho de estudar o legado da autora, mais a sociedade tem a ganhar. Carolina é um símbolo de resistência, referência, um ícone no tocante à questão da representatividade. Por muito tempo representou quase que isoladamente a categoria dos negros e pobres na história da literatura, sua literatura não é modesta, e apesar das dificuldades experienciadas ao longo de sua vida, a escritora deixa um legado de orgulho. Regina Dalcastagnè (2012) ao falar de Carolina afirma que:

"Como qualquer texto literário, o seu pode ser aproveitado como objeto de estudo da Sociologia ou de outras áreas do conhecimento, mas isso não quer dizer que não seja material estético a ser analisado, portanto, também esteticamente. $O$ fato de ela ser negra, pobre, catadora de lixo não pode ser usado para transformá-la numa personagem exótica, apagando sua autoridade enquanto autora."

(DALCASTSGNÈ, Regina, 2012, p. 24)

O grande equívoco em relação à crítica foi enxergar o trabalho de Carolina a partir de perspectivas estigmatizantes. A autora não se enquadrava em um padrão que era o esperado naquela época. Ela não tinha a cor exigida, ela não era casada, tinha três filhos, teve poucos anos de escolarização, era mulher e favelada. E mesmo assim não se permitiu submissa, tinha suas convicções e não via problemas em apresentá- 
las. Sua visão sobre o casamento, por exemplo, era algo incompatível com seu período. Divórcio era um tema tabu, em 1960 a indissolução não era prevista em lei, havia apenas a possibilidade da separação de corpos dentro de critérios previamente estabelecidos. Carolina não tratava do tema divórcio, ela simplesmente apontava que o casamento era algo que prendia as mulheres, mostrando sempre os aspectos negativos.

Estudar, ter contato com o trabalho de Carolina Maria de Jesus já no século XXI é oferecer à sociedade a oportunidade de conhecer uma escritora que não foi entendida em seu período, é desfazer uma injustiça histórica, é acrescentar positivamente a importância da variabilidade da questão da representação, já que o Brasil é um país extremamente desigual e racista. É preciso reler Carolina, redescobrila no século XXI para que somente então ela possa ser compreendida. 


\section{Conclusão}

Através do referido trabalho foi possível dimensionar de modo mais detalhado a extensão da produção de Carolina Maria de Jesus, isso possibilitou também, a reiteração de que Carolina é uma autora complexa, inserida em um contexto social marginalizado que não a compreendeu. A utilização da estratégia de releitura possibilitou a aproximação entre os autores marginais/periféricos dos anos 2000 e a escrita de Carolina nos anos 1960, essa intercessão situou as diferenças geracionais, mas também corroborou para a interpretação de que a autora foi redescoberta no século XXI e há uma compreensão mais compatível em relação a sua literatura. Carolina é um ícone e o tempo está se encarregando de desfazer a interpretação reducionista de seu legado artístico.

Vivenciamos um processo peculiar em relação à literatura, já que a grande circulação de textos na internet trouxe mais visibilidade para essa manifestação cultural, mas ao mesmo tempo presenciamos o enfraquecimento das editoras no Brasil. A literatura se expandiu, ela hoje é também oral, está nos aparelhos eletrônicos, nas redes, nas "rodas" e "batalhas" das mais diversas periferias e não periferias do país. A literatura se faz presente também nos bares, por meio dos saraus, dando mais expressividade e possibilidades àqueles que não podem chegar até a biblioteca, ao museu, à livraria. Assim, a finalidade desse trabalho se cumpre não no sentido de completude, até porque se trata de uma breve reflexão sobre escritas marginais tendo em vista os escopos da escrita feminina e os movimentos marginais do século XXI, mas se efetiva no sentido de possibilitar reflexões sobre as mudanças de cenário e a amplitude da escrita no Brasil.

É preciso que as literaturas das minorias, os acenos intelectuais e culturais dessas mesmas minorias se façam presentes nas instituições que difundem o saber, que sejam contempladas nos currículos escolares, ofertadas como cursos livres e que cada vez mais ocupem os espaços de pesquisa. A separação social assinalada pela divisão nós/eles, além de injusta, proporciona problemas sociais irreparáveis, para além da falta de representantividade para os alunos mais pobres na educação básica e a ideia limitadora de que a literatura pertence a uma classe social, a ocultação e negligência de tais conteúdos resultam na pobreza intelectual. A Literatura é, sobretudo, um Direito Humano, portanto, inegociável e inalienável. Carolina persistiu por um direito que Ihe foi negado, ela foi exemplo, e é modelo de inspiração para aqueles que a escrita é algo longe, quase inalcançável. 


\section{Referências Bibliográficas}

BARTHES, Roland. O prazer do texto. São Paulo: Perspectiva, 1993.

. O rumor da língua. Tradução de Mario Laranjeira. 2. ed. São Paulo:

Martins Fontes, 2004.

BOSI, A. História concisa da Literatura Brasileira. São Paulo: Cultrix, 2003.

CANDIDO, A. Literatura e Sociedade. Rio de Janeiro, Ouro sobre Azul, 2006. Formação da literatura brasileira. São Paulo: Edusp, 1975.

O direito à literatura. In: Vários Escritos. São Paulo: Duas

Cidades, 1995. p.169-191.

CASCUDO, Luis da Câmara. Vida breve de Auta de Souza (1876-1901).

Recife: Imprensa Oficial, 1961.

COMPAGNON, Antoine. O demônio da literatura: literatura e senso comum.

Tradução de Cleonice Paes Barreto Mourão e Consuelo Fortes Santiago. 2. ed. Belo Horizonte: Editora UFMG, 2010.

2009. Literatura pra quê?. Belo Horizonte: Editora UFMG,

CLÜVER, Claus. Intermidialidade. Pós: Belo Horizonte, v. 1, n.2, 8-23, nov. 2011.

Inter textus / inter artes / inter media. Aletria: Revista de estudos de literatura, Belo Horizonte, n. 14, 11-41, jul./dez. 2006.

DALCASTAGNÈ, Regina. Literatura brasileira contemporânea um território contestado. Rio de janeiro, editora UERJ, 2012.

GOMES, Ana Laudelina Ferreira. Auta de Souza: representações culturais e imaginação poética. Tese (Doutorado em Ciências Sociais) - Pontifícia Universidade Católica, São Paulo, 2000.

GOMES, Nilma Lino. Um olhar além das fronteiras. Editora Autêntica: BeloHorizonte, 2010.

EVARISTO, Conceição. Da representação à auto-representação da mulher negra na literatura brasileira. Revista Palmares: cultura afro-brasileira, ano1n 1, p.52 -57. 2005.

Janeiro: Malê, 2017.

Poemas da recordação e outros movimentos. Rio de

FERRÉZ.(Org.) Literatura marginal: talentos da escrita periférica, Rio de Janeiro. Editora Agir, 2005.

FREIRE, Marcelino. Trabalhadores do Brasil In: Contos Negreiros, Rio de janeiro, Editora 1999.

HALL, Stuart. Que negro é esse na cultura negra? In: Da Diáspora: Identidades e mediações culturais. Belo Horizonte. Editora UFMG, 2006.

Significação, representação, ideologia. In: Da Diáspora: Identidades e mediações culturais. Belo Horizonte. Editora UFMG, 2006.

JOBIM, José Luís (org). Cânon. Palavras da crítica. Rio de Janeiro: Imago, 1992.

MUNANGA, Kabengele. Uma abordagem conceitual das noções de raça, racismo, identidade e etnia. In: Cadernos PENESB. Programa de Educação sobre o Negro na Sociedade Brasileira. Niterói, Rio de Janeiro. N5. p. 15-23, 2004. 
NASCIMENTO, Érica Peçanha do. Vozes marginais na literatura. Coleção Tramas Urbanas, Rio de Janeiro. Aeroplano, 2009.

É tudo nosso! Produção cultural na periferia paulistana. Tese de doutorado - Faculdade de Filosofia, Letras e Ciências Humanas da Universidade de São Paulo, Disponível em: consultado em: outubro de 2013.

ORTIZ, Renato. Cultura brasileira e identidade nacional. Brasiliense, São paulo, 2006.

RIBEIRO, Darcy. Introdução In: O povo Brasileiro, Companhia de Bolso, São Paulo,

RIBEIRO, Djamila. Quem tem medo do feminismo negro. Companhia das Letras, São Paulo, 2018.

SALLES, Écio. Poesia Revoltada - coleção tramas urbanas. Rio de Janeiro, Editora Aeroplano, 2010.

SOVIK, Liv. Aqui ninguém é branco. Rio de Janeiro, Aeroplano, 2009.

SILVA, Consuelo Dores. Negro, qual é o seu número? Belo Horizonte: Mazza ITDA, 2004.

SOUZA, Auta de. Horto, outros poemas e ressonâncias. Obras reunidas de Auta de Souza. Organização de Alvamar Medeiros, Ana Laudelina F. Gomes e Angelita Araújo. Natal: EDUFRN. 2009.

JESUS, Carolina Maria de. Antologia Pessoal. Organização de José Carlos Sebe Bom Meihy; [revisão de] Armando Freitas Filho. Rio de Janeiro, Editora UFRJ, 1996.

Casa de Alvenaria: diário de uma ex-favelada. São Paulo: Livraria Francisco Alves, 1961.

Diário de Bitita. Rio de Janeiro: Nova Fronteira, 1986.

Meu Estranho Diário. São Paulo: Xamã, 1996.

1994.

Quarto de Despejo: diário de uma favelada. São Paulo: Ática,

MEIHY, José Carlos Sebe Bom. Carolina Maria de Jesus: emblema do silêncio. Revista USP, São Paulo, n. 37, 1998.

ROSA, A. S. da. Zagaia. São Paulo: DCL, 2007.

.e GUMA. Morada. São Paulo: Edições Toró, 2007.

Da Cabula. São Paulo: Global Editora, 2008. 98 p. 